\title{
(ख)
}

AUTARQUIA ASSOCIADA À UNIVERSIDADE DE SÃO PAULO

\section{AVALIAÇÃO DA VIABILIDADE DE BIOSSORVENTES ALTERNATIVOS NA RECUPERAÇÃO DE CORPOS HÍDRICOS CONTAMINADOS POR DERRAMAMENTO DE DERIVADOS DO PETRÓLEO}

TATIANA MARTINEZ MOREIRA

Dissertação apresentada como parte dos requisitos para obtenção do Grau de Mestre em Ciências na Área de Tecnologia Nuclear - Materiais

Orientadora:

Profa. Dra. Emília Satoshi Miyamaru Seo 
INSTITUTO DE PESQUISAS ENERGÉTICAS E NUCLEARES

Autarquia associada à Universidade de São Paulo

\section{AVALIAÇÃO DA VIABILIDADE DE BIOSSORVENTES ALTERNATIVOS NA RECUPERAÇÃO DE CORPOS HÍDRICOS CONTAMINADOS POR DERRAMAMENTO DE DERIVADOS DO PETRÓLEO}

\section{TATIANA MARTINEZ MOREIRA}

Dissertação apresentada como parte dos requisitos para obtenção do Grau de Mestre em Ciências na Área de Tecnologia Nuclear - Materiais

Orientadora:

Profa. Dra. Emília Satoshi Miyamaru Seo

Versão Corrigida

São Paulo 
Fonte de Financiamento: CNPq - Processo n. 134160/2016-9. GM/GD - Cotas do Programa de Pós-Graduação

Autorizo a reprodução e divulgação total ou parcial deste trabalho, para fins de estudo e pesquisa, desde que citada a fonte.

MOREIRA, T. M. Avaliação da viabilidade de biossorventes alternativos na recuperação de corpos hídricos contaminados por derramamento de derivados do petróleo. 2018. 109 p. Dissertação (Mestrado em Tecnologia Nuclear Materiais), Instituto de Pesquisas Energéticas e Nucleares, IPEN-CNEN/SP, São Paulo. Disponível em: www.teses.usp.br (data da consulta no formato: dd/mm/aaaa).

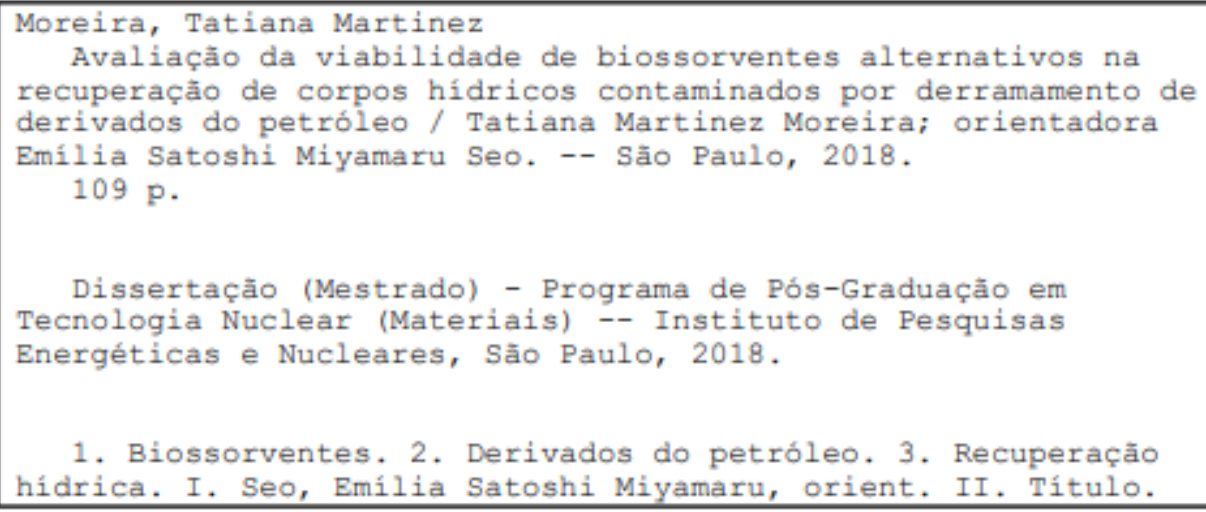




\section{AGRADECIMENTOS}

Agradeço à Dra. Emília Satoshi Miyamaru Seo, pela oportunidade de tê-la como orientadora, pela amizade, apoio e incentivo.

À Dra. Denise Alves Fungaro, pelo apoio durante o desenvolvimento de toda a pesquisa. Muito obrigada!

Ao técnico de laboratório Marco Andreoli, pelo incentivo e apoio durante os ensaios experimentais.

Aos laboratórios e Centros de Pesquisa (CCTM, CQMA, CCN), que contribuíram com análises fundamentais para realização desta pesquisa.

À minha mãe Marisa e ao meu irmão Diego, por estarem sempre presentes e me apoiarem incondicionalmente para que eu conseguisse realizar este trabalho.

Aos meus amigos presentes durante o andamento do mestrado, pela amizade, apoio incondicional e incentivo em todos os momentos que precisei.

Ao Conselho Nacional de Desenvolvimento Científico e Tecnológico, por tornar possível a realização desta pesquisa por meio da concessão de bolsa de estudo. 
"Nossa vida é uma constante viagem, do nascimento á morte. A paisagem muda, as pessoas mudam, as necessidades se transformam, mas o trem segue adiante. $A$ vida é o trem, não a estação"

Paulo Coelho 


\section{RESUMO}

MOREIRA, Tatiana. M. M.. Avaliação da viabilidade de biossorventes alternativos na recuperação de corpos hídricos contaminados por derramamento de derivados do petróleo. 2018. 109 p. Dissertação (Mestrado em Tecnologia Nuclear Materiais) - Instituto de Pesquisas Energéticas e Nucleares - IPEN-CNEN/SP. São Paulo.

Acidentes ambientais vêm ocorrendo ao longo de décadas, assim, além de atitudes para evitar esses danos, são necessárias ações para remediação. Materiais tecnológicos e de baixo custo em impacto ambiental podem ser uma alternativa para o tratamento de corpos hídricos degradados, além de um caminho ambientalmente sustentável para remediação de córregos e rios urbanos. Neste contexto, buscou-se avaliar na pesquisa, materiais biossorventes para serem utilizados em acidentes de derramamento de derivados do petróleo em meio aquático. Como matéria-prima, utilizaram-se as fibras das cascas de banana, coco e laranja. Como contaminantes foram utilizados a gasolina e o óleo diesel. Os biossorventes foram produzidos por processos de secagem, ativação química, moagem, classificação granulométrica, caracterização e ensaios de sorção. Para a caracterização foram empregadas as técnicas: picnometria, termogravimetria, análise elementar, microscopia eletrônica de varredura, teor de umidade, retenção de água pela biomassa seca, hidrofobicidade, flutuabilidade, teor de cinzas, fluorescência de raios $X$ e classificação granulométrica. Para o tratamento dos dados, desenvolveu-se um planejamento estatístico de identificação das variáveis significativas no processo de sorção, construíram-se curvas de equilíbrio e de cinética de sorção e que foram modeladas por meio das isotermas de Freundlich e Langmuir. Para estudo da influência da granulometria na sorção, os ensaios foram realizados com os grãos primeiramente de maneira generalizada e posteriormente separados por granulometrias distintas. Os resultados se mostraram promissores, sendo o coco o biossorvente mais eficiente, ele sorveu uma média de $3,94 \mathrm{~g} / \mathrm{g}$ de óleo diesel e 2,80 g/g de gasolina.

Palavras-chave: biossorventes; derivados do petróleo; recuperação hídrica. 


\begin{abstract}
MOREIRA, Tatiana. M. M.. Assessment of the viability of alternative biosorbents in the recovery of water bodies contaminated by oil spills. 2018. 109 p. Dissertação (Mestrado em Tecnologia Nuclear Materiais) - Instituto de Pesquisas Energéticas e Nucleares - IPEN-CNEN/SP. São Paulo.
\end{abstract}

Environmental accidents have been occurring for decades, then, in addition to attitudes to avoid such damages, remediation actions are required. Technological materials of low cost and environmental impact may be an alternative for the treatment of degraded water bodies, besides an environmentally sustainable way for remediation of streams and urban rivers. In this context, it was sought to evaluate, in the research, biosorbent materials to be used in accidents of spill of oil derivatives in aquatic environment. The fibers of the banana, coconut and orange crusts were used as raw material. Petrol and diesel were used as contaminants. The biosorbents were produced by processes such as, drying, chemical activation, milling, sorting, characterization and sorption tests. For the characterization, the techniques used were: picnometry, thermogravimetry, elemental analysis, electron microscopy, moisture content, water retention by dry biomass, hydrophobicity, buoyancy, ash content, X - ray fluorescence and granulometric classification. For the treatment of the data, a statistical design was developed to identify the significant variables in the sorption process, equilibrium and sorption kinetics curves were constructed and modeled, using the Freundlich and Langmuir isotherms. To study the influence of granulometry on sorption, the tests were performed with the grains first generalized and later separated by different granulometries. The results were promising, with coconut being the most efficient biosorbent, it had an average of $3,94 \mathrm{~g} / \mathrm{g}$ of diesel oil and $2,80 \mathrm{~g} / \mathrm{g}$ of gasoline.

Keywords: biosorbents; petroleum products; water recovery. 


\section{SUMÁRIO}

$1 \quad$ INTRODUÇÃO

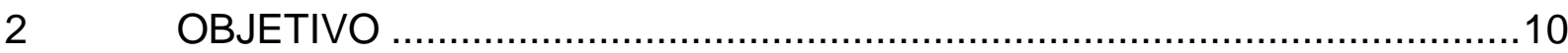

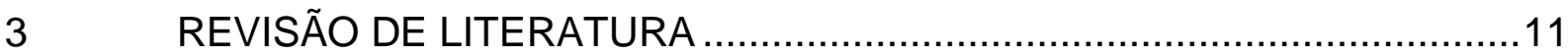

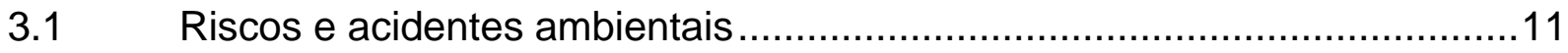

3.2 Legislação ambiental para derramamento de óleo ..................................14

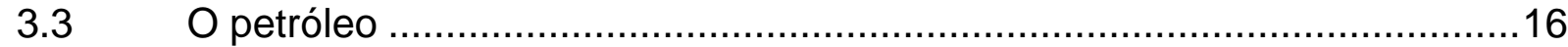

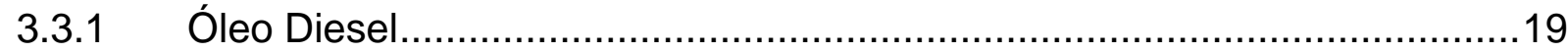

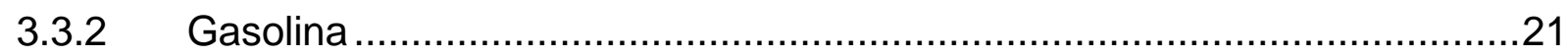

3.4 Sorção, adsorção, biossorção: fenômenos interligados ...........................22

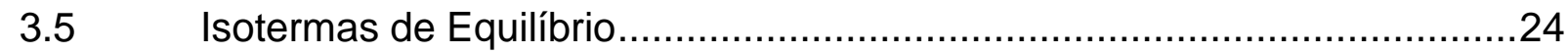

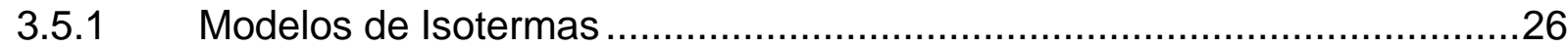

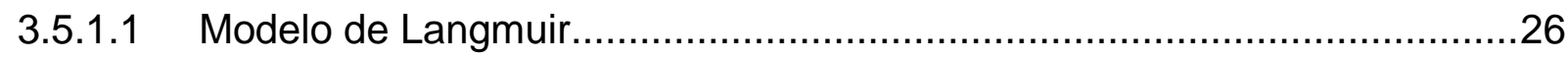

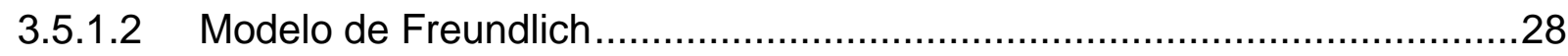

3.5.1.3.1 Cinética de sorção..........................................................................29

3.5.1.4 Ligações de hidrogênio, estrutura da água e o efeito hidrofóbico ..............30

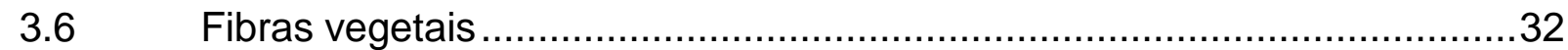

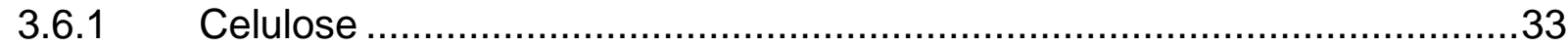

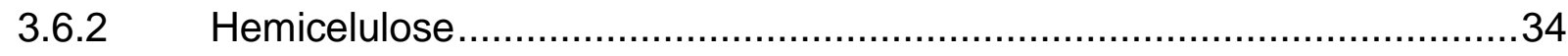

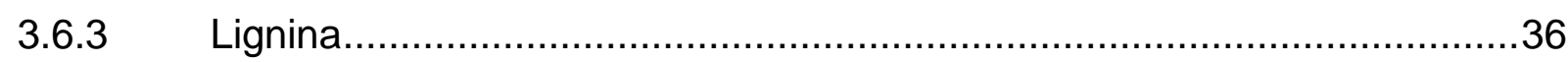

3.6.4 Ativação dos biossorventes através da modificação química ...................37

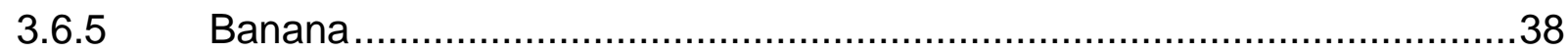

3.6.6 Coco

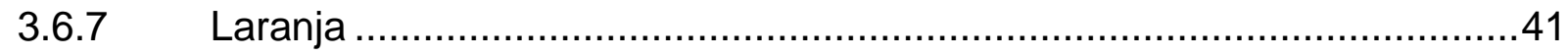

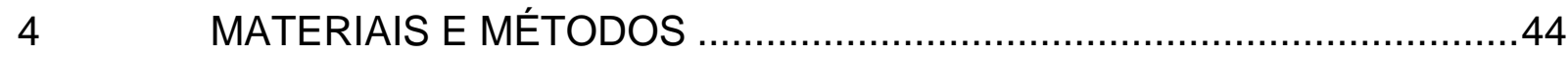

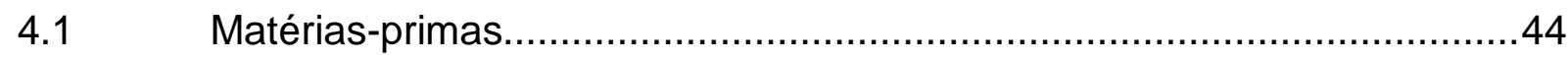

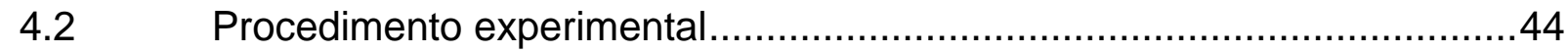

4.3 Obtenção e processamento dos biossorventes ....................................44

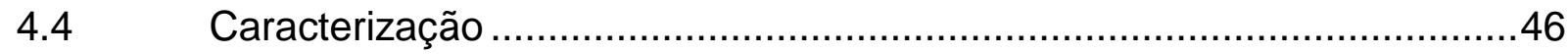

4.4.1 Ensaios de sorção dos contaminantes ...............................................50

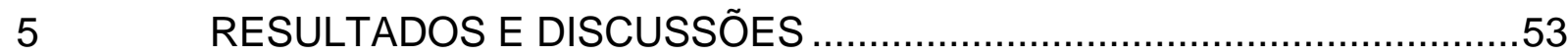


5.1 Caracterização dos materiais biossorventes .......................................53

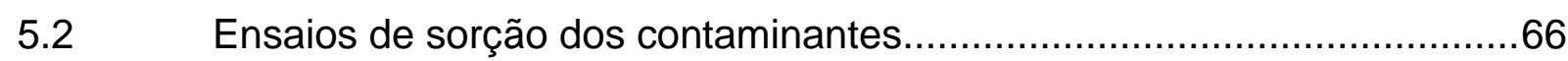

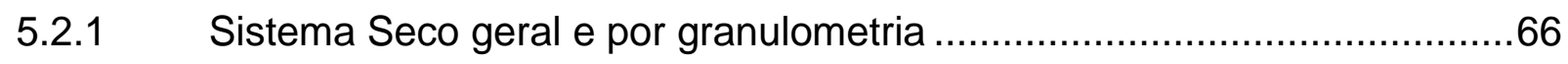

5.2.2 Sistema Aquoso geral e por granulometria .........................................73

5.3 Isotermas de sorção em emulsões óleo/água..........................................82

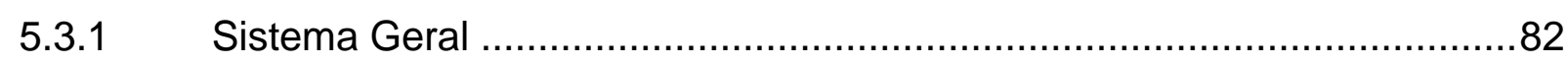

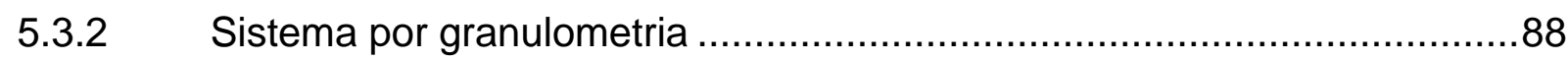

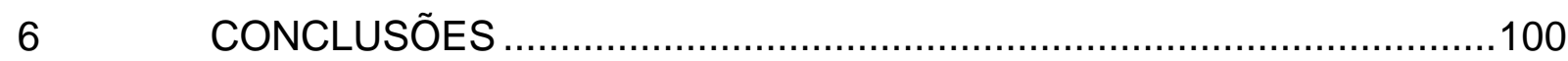

7 REFERÊNCIAS BIBLIOGRÁFICAS ............................................... 102 


\section{INTRODUÇÃO}

O trinômio energia, desenvolvimento e degradação, se fizeram presentes durante milhares de anos em todas as grandes civilizações. A lógica da época era muito simples, e assemelha-se em muitos aspectos com a que utilizamos até hoje. $O$ desenvolvimento era pautado na busca incessante de uma fonte energética que gerasse o custo benefício mais atraente, e isso era tudo, não havia outras preocupações (AQUINO et al., 2015).

Pott e Estrela (2017), citam que atualmente os reflexos da evolução nas políticas ambientais iniciada principalmente após a década de 1960 são visíveis. O enfrentamento quanto à problemática ambiental por meio dos instrumentos de gestão instituídos por políticas públicas, que surgiram no auge das discussões sobre o meio ambiente, mostrou-se como a possível saída para a redução e mitigação da degradação ambiental.

Mesmo com essa visão ambiental atual, Aquino et al., (2015), menciona que o petróleo tende a permanecer como a principal fonte energética, embora com diminuição da sua participação ( 30\%). Outras fontes como o gás natural e carvão, tendem a um aumento da participação na matriz energética mundial.

Além das questões ambientais relacionadas com as matrizes energéticas e políticas públicas, outro ponto que levanta discussões e exige atenção são os recursos hídricos. Arêdes et al., (2013) menciona que, como constituinte estratégico dos sistemas ambientais, a água tem atraído a atenção de pesquisadores, políticos e das sociedades em geral, preocupados com o atual estágio de degradação dos mananciais hídricos do globo. Costumeiramente considerada como recurso infinito e renovável, a água vem adquirindo posição de recurso econômico, e sua escassez vem alertando sobre os riscos do desequilíbrio entre sua disponibilidade e demanda.

Dados estatísticos da Agência Nacional de Águas (2014), demonstraram que desde o segundo semestre de 2012, tem-se observado um comportamento pluviométrico bem abaixo da média em diferentes regiões do Brasil, com crise severa entre 2014 e 2015, onde diversos sistemas de água ficaram abaixo do nível de operação. A Região Metropolitana de São Paulo foi gravemente afetada, onde 
decretou-se abrangente crise hídrica. O Sistema Cantareira, por exemplo, ficou operando abaixo do nível, no intitulado volume morto de maio de 2014 a dezembro de 2015.

Outro problema que agrava a situação dos corpos hídricos, são os acidentes ambientais, que vêm ocorrendo ao longo de décadas. Os córregos e rios de grandes centros urbanos, como São Paulo, encontram-se severamente degradados e derramamentos oleosos ocorrem com frequência. Além de atitudes para evitar esses danos, são necessárias ações para remediação. Materiais tecnológicos e de baixo custo e impacto ambiental podem ser uma alternativa para o tratamento de corpos hídricos degradados, além de um caminho ambientalmente sustentável para remediação de córregos e rios urbanos.

Os sorventes comerciais mais utilizados atualmente são os materiais sintéticos, feitos de polipropileno e poliuretano. Eles possuem características favoráveis como: baixa densidade, baixa sorção de água, boa resistência física e química e boa sorção de óleo. Mas destaca-se como desvantagem desses materiais o fato de não serem biodegradáveis (BORGES, 2015).

Neste contexto, buscou-se avaliar na pesquisa, materiais biossorventes para serem usados no derramamento de derivados do petróleo em meio aquático. Para atingir o objetivo realizou-se a caracterização das fibras adotadas como biossorventes, desenvolveu-se um planejamento estatístico para a identificação das variáveis significativas no processo de sorção investigado, construiu-se curvas de equilíbrio e de cinética de sorção e modelou-se o equilíbrio da sorção por meio das isotermas de Freundlich e Langmuir.

A relevância da pesquisa se dá pela oportunidade de explorar técnicas que possam contribuir com o desenvolvimento do saneamento e da reciclagem, por meio de alternativas sustentáveis. Dessa forma, há um incentivo para a recuperação de corpos hídricos urbanos, que em grande parte se encontram severamente degradados. 


\section{OBJETIVO}

O objetivo do presente trabalho foi preparar e avaliar a viabilidade de biossorventes produzidos a partir das cascas da banana, do coco e da laranja e analisar a influência da granulometria nestes materiais. Os biossorventes foram empregados na sorção de derivados do petróleo, como o óleo diesel e a gasolina, para a recuperação de corpos hídricos urbanos contaminados por estes óleos. 


\section{REVISÃO DE LITERATURA}

\subsection{Riscos e acidentes ambientais}

A contaminação dos solos e de mananciais hídricos (superficiais e subterrâneos) por hidrocarbonetos derivados de petróleo tem sido bastante discutida nas últimas décadas. As ações que integram o campo da gestão ambiental estão sendo arroladas em diferentes cenários. Elas dependem de articulações políticas, econômicas e sociais, para que haja espaço para discussão de alternativas, metas de prevenção e investimento em pesquisa de novas tecnologias, para identificação e recuperação do solo e mananciais hídricos contaminados (VIVIAN, 2015).

As indústrias de petróleo lidam frequentemente com problemas decorrentes de vazamentos, derrames e acidentes durante a exploração, refinamento, transporte, e operações de armazenamento do petróleo e seus derivados (CORSEUIL E MARINS, 1998). Ao analisarem-se os combustíveis derivados de petróleo, os quais movimentam a grande indústria dos transportes, vê-se a necessidade de investimento em infraestrutura e logística para atender o mercado (VIVIAN, 2015).

Em um derramamento de gasolina, uma das principais preocupações é a contaminação de aquíferos que sejam usados como fonte de abastecimento de água para consumo humano. A gasolina contém mais de 400 componentes e é pouco solúvel em água se dissolvendo de forma parcial.

Os hidrocarbonetos mono aromáticos: benzeno, tolueno e xilenos, chamados BTEX são os componentes presentes na gasolina que possuem maior solubilidade em água e, portanto, são os primeiros contaminantes a atingir o lençol freático. Estes compostos são considerados substâncias perigosas por serem depressoras do sistema nervoso central. O benzeno é comprovadamente carcinogênico podendo causar leucemia (CORSEUIL E MARINS, 1998).

Compostos oriundos de diesel e óleos lubrificantes possuem cadeias mais longas, o que contribui para menores mobilidade e solubilidade em água, quando comparados à gasolina. Os PAH's (hidrocarbonetos aromáticos policíclicos) são 
componentes presentes no diesel e óleo lubrificante também considerados de potencial carcinogênicos (CORSEUIL E MARINS, 1997).

Ao longo das décadas inúmeros acidentes envolvendo derramamento de petróleo ocorreram ao redor do mundo. Analisando o histórico dos principais incidentes envolvendo poluição por óleo no Brasil, observa-se que os primeiros registros, entre 1960/1980, estão relacionados com transporte marítimo e liberaram os maiores volumes. Nos anos seguintes, as ocorrências passaram a ser em oleodutos, terminais e refinarias de várias partes do país e com volumes menores (CETESB a, 2018).

Pode-se citar alguns acidentes recentes envolvendo os combustíveis gasolina e óleo diesel. Em 9 de março de 2018 um ônibus caiu na represa Paiva Castro, em Mairiporã, depois de se envolver em um acidente com um carro na Rodovia Luis Salomão Chamma (divisa com Franco da Rocha - SP).

O óleo do ônibus vazou e se espalhou pela represa. Equipes de resgate da CETESB colocaram uma boia para controlar a mancha de óleo para posteriormente retirar o veículo da represa (figura 1) (G1a, 2018).

Figura 1 - Ônibus bate em carro e cai em represa na Grande SP.

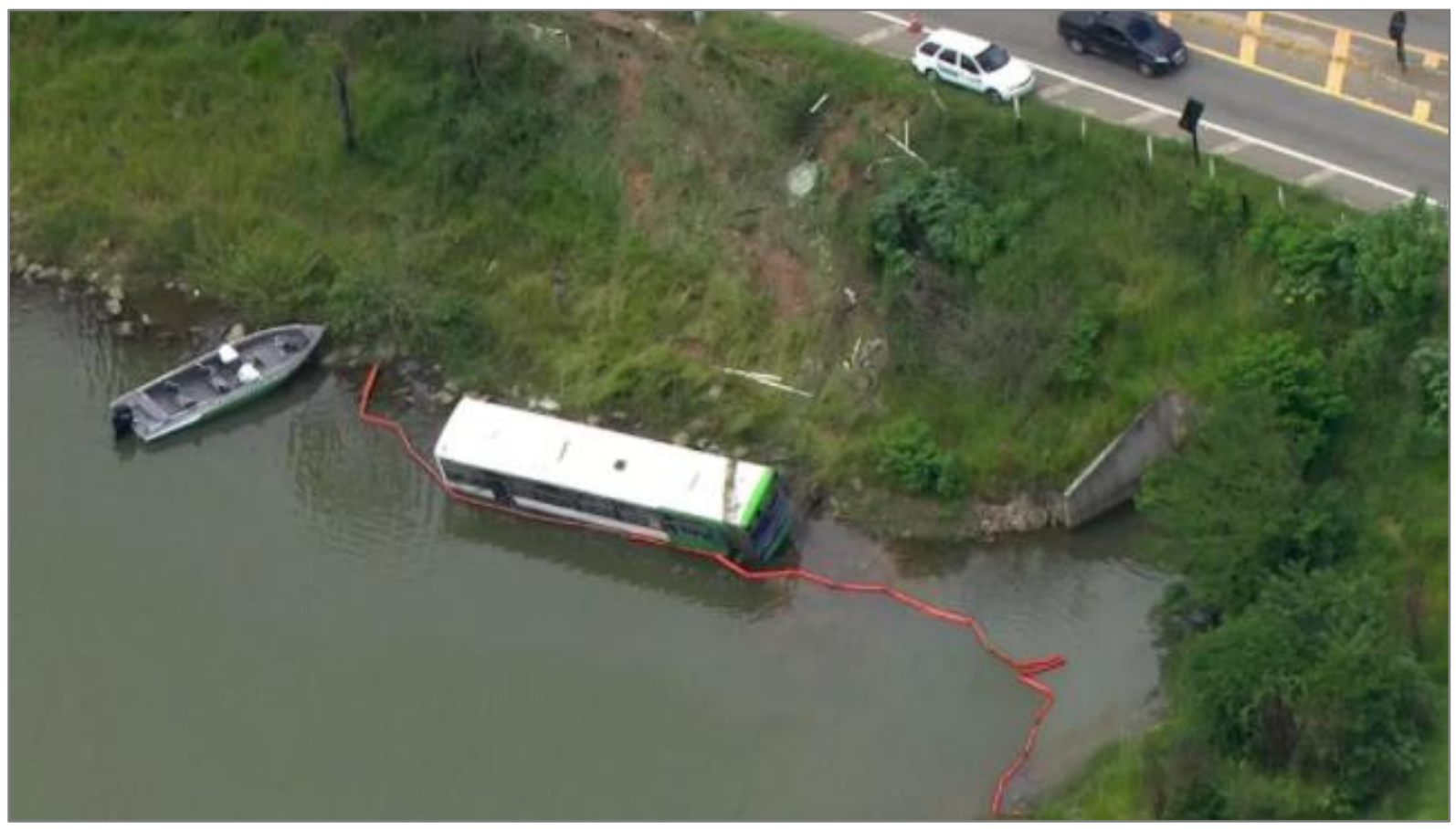

Fonte - G1a, 2018. 
Em 26 de janeiro de 2018 foi encontrada uma mancha de óleo no rio Tietê, de acordo com dados da reportagem feita pelo G1, a mancha iniciou a partir de um córrego em uma rua adjacente ao rio, em uma área bastante industrializada. Através do sistema de drenagem ao lado da Ponte da Vila Maria (SP), foi se espalhando por 4 km de extensão (figura 2).

A CETESB foi ao local no dia seguinte, encontrando a mancha alastrada sobre a água, segundo os técnicos responsáveis, foi calculado um volume de aproximadamente 500 litros de óleo. Não foi tomada nenhuma medida corretiva, o óleo acabou sucumbindo em meio a água (G1b, 2018).

Figura 2 - CETESB investiga mancha em rio Tietê.

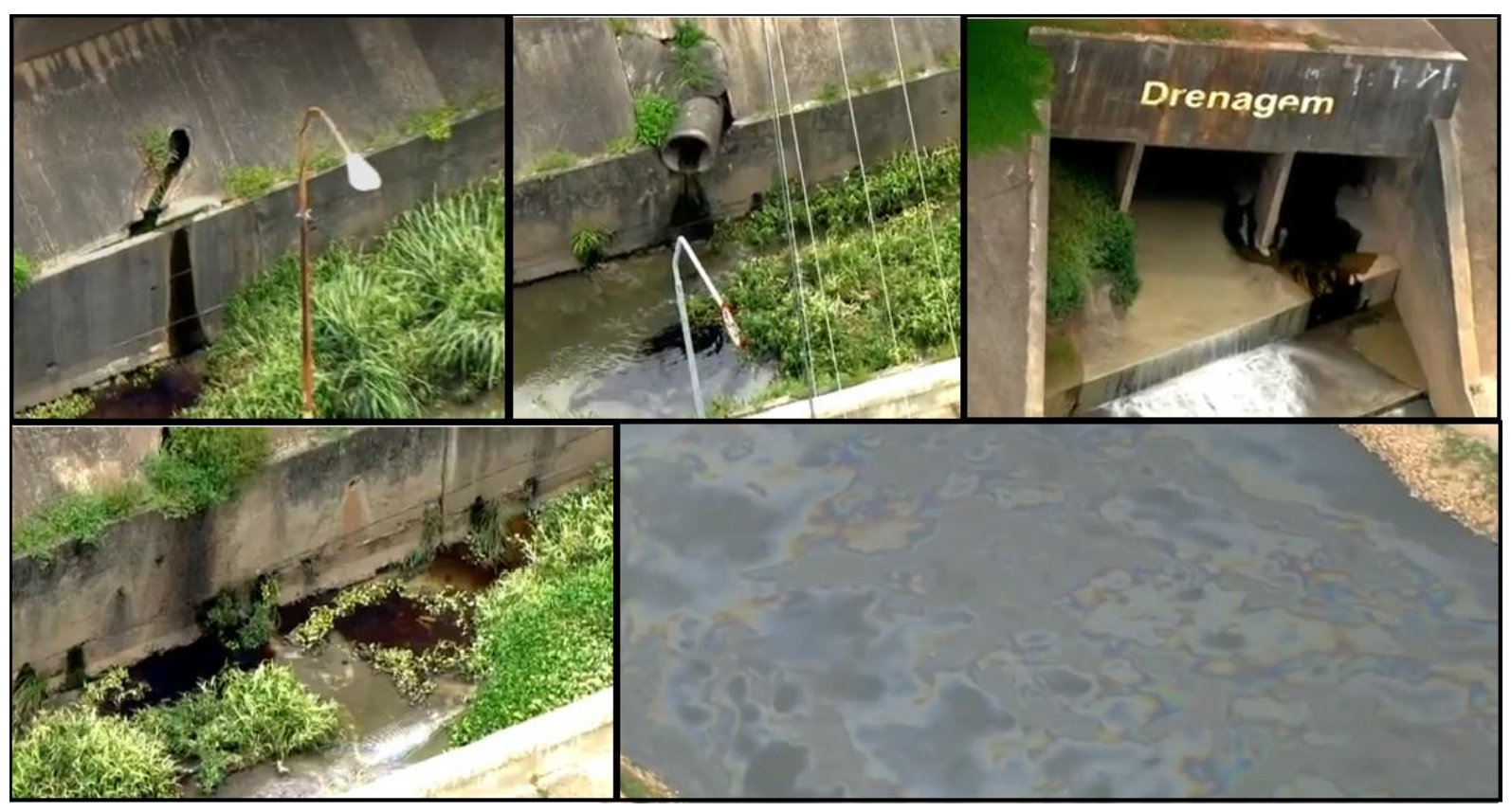

Fonte - G1b.

Em 18 de agosto de 2017 um acidente envolvendo um trem da empresa Rumo Logística, na Estação Paratinga, zona rural de São Vicente (SP), provocou derramamento de quase 12 mil litros de óleo diesel, que atingiu um riacho nas imediações (figura 3). 
O acidente ocorreu durante manobra dentro do pátio da empresa, causando o rompimento do tanque de combustível da composição, o que gerou vazamento de parte do produto para o solo, atingindo um pequeno corpo d'água.

Segundo a reportagem, o trem não descarrilou, mas, por alguma razão, o tanque do combustível se desprendeu da composição e o óleo atingiu dois córregos próximos (A TRIBUNA, 2018).

Figura 3 - Vazamento de óleo proveniente de acidente em manobra de trem.

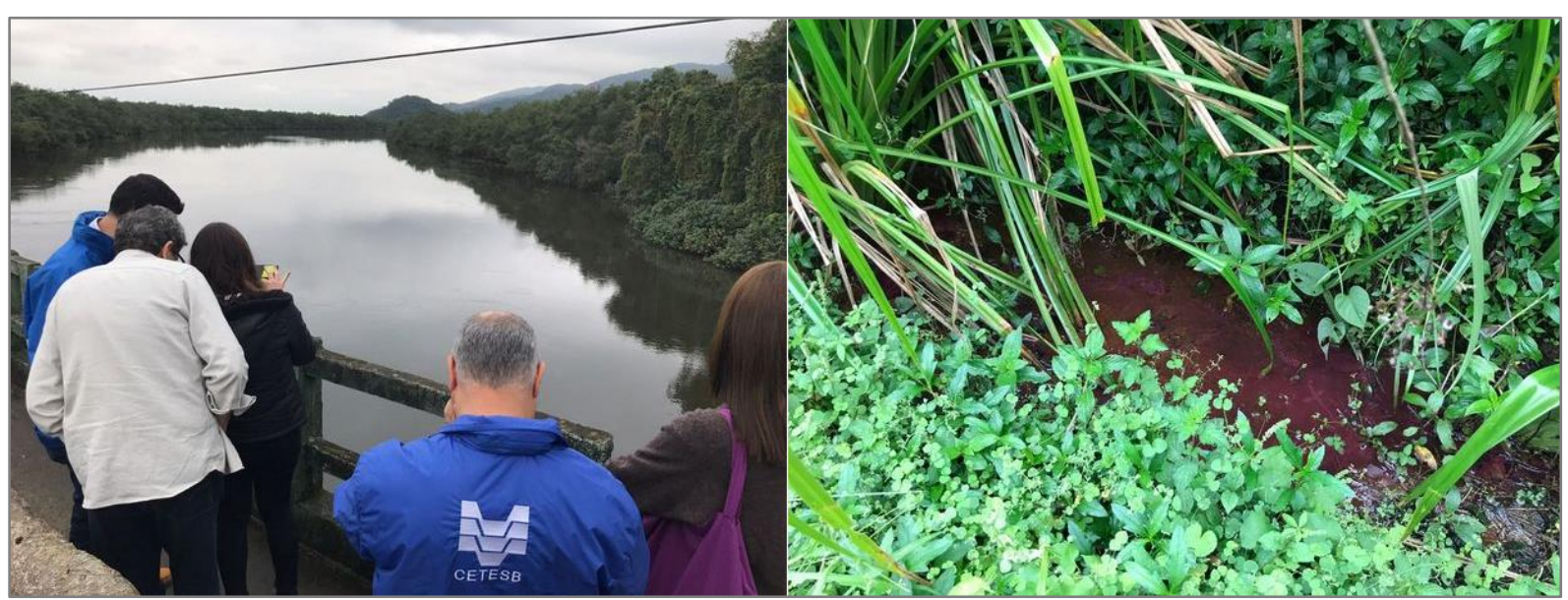

Fonte - A TRIBUNA, 2017.

Em janeiro de 2015 um caminhão que transportava gasolina tombou e derramou em um córrego cerca de 15 mil litros do combustível. O acidente ocorreu no Estado do Paraná, técnicos responsáveis da Secretaria do Verde e Meio Ambiente juntamente com os bombeiros tomaram medidas de contenção com boias para reter o combustível (ANDRÉ, 2018).

\subsection{Legislação ambiental para derramamento de óleo}

Existem diversas leis que tratam sobre derramamentos oleosos no Brasil, a tabela 1 apresenta em síntese essas legislações relacionadas a poluição por óleo, em âmbito federal (leis, decretos e resoluções CONAMA) e estadual (CETESB b, 2018). 
Tabela 1 - Síntese dos instrumentos legais relacionados a prevenção e controle da poluição por óleo.

\begin{tabular}{|c|c|}
\hline & $9 ;$ \\
\hline $\begin{array}{l}\text { Comunicação } \\
\text { do vazamento } \\
\text { de óleo }\end{array}$ & $\begin{array}{l}\text { Portaria da Agência Nacional de Petróleo: № 170/98 - Art. 13; } \\
\text { Lei de Crimes Ambientais: Lei Federal № 9.605/98 - Art. 14; } \\
\text { "Lei do óleo e de substâncias nocivas" - Lei Art. } 22 \text {. }\end{array}$ \\
\hline $\begin{array}{c}\text { Planos de } \\
\text { Emergência }\end{array}$ & $\begin{array}{l}\text { Lei dos Portos: Lei Federal № 8.630/93 - Art. } 33 \text { §1-inciso VII; } \\
\text { Lei Federal N. 9.719/98 e NR 29/97: Norma Regulamentadora de Segura } \\
\text { Saúde no Trabalho Portuário - Itens: 29.1.6, 29.6.3.4 e 29.6.6; } \\
\text { "Lei do óleo e de substâncias nocivas”: Lei Federal № 9.966/2000; } \\
\text { Plano de Emergência Individual - Resolução CONAMA № 398/2008, } \\
\text { Plano de Área para combate à poluição por óleo Dec. Fed. № 4.871/2003. }\end{array}$ \\
\hline $\begin{array}{l}\text { Prevenção } \\
\text { da poluição } \\
\text { aquática }\end{array}$ & $\begin{array}{l}\text { Prevenção da poluição origem terrestre: Portaria do Minist. dos Transp. № 124/80; } \\
\text { Política Nacional de Meio Ambiente: Lei Federal № 6.938/81; } \\
\text { Lei de Segurança do Tráfego Aquaviário (LESTA): Lei Federal № 9.537/97; } \\
\text { "Lei do óleo e de substâncias nocivas”: Lei Federal № 9.966/2000; } \\
\text { Procedimentos para transferência de óleo entre embarcações - NORMAM } 08 \text { com } \\
\text { alterações de } 2010 \text { - Cap. } 3 \text { - Seção IV - Item } 308 \text {. }\end{array}$ \\
\hline $\begin{array}{l}\text { Penalidades aos } \\
\text { agentes } \\
\text { poluidores }\end{array}$ & 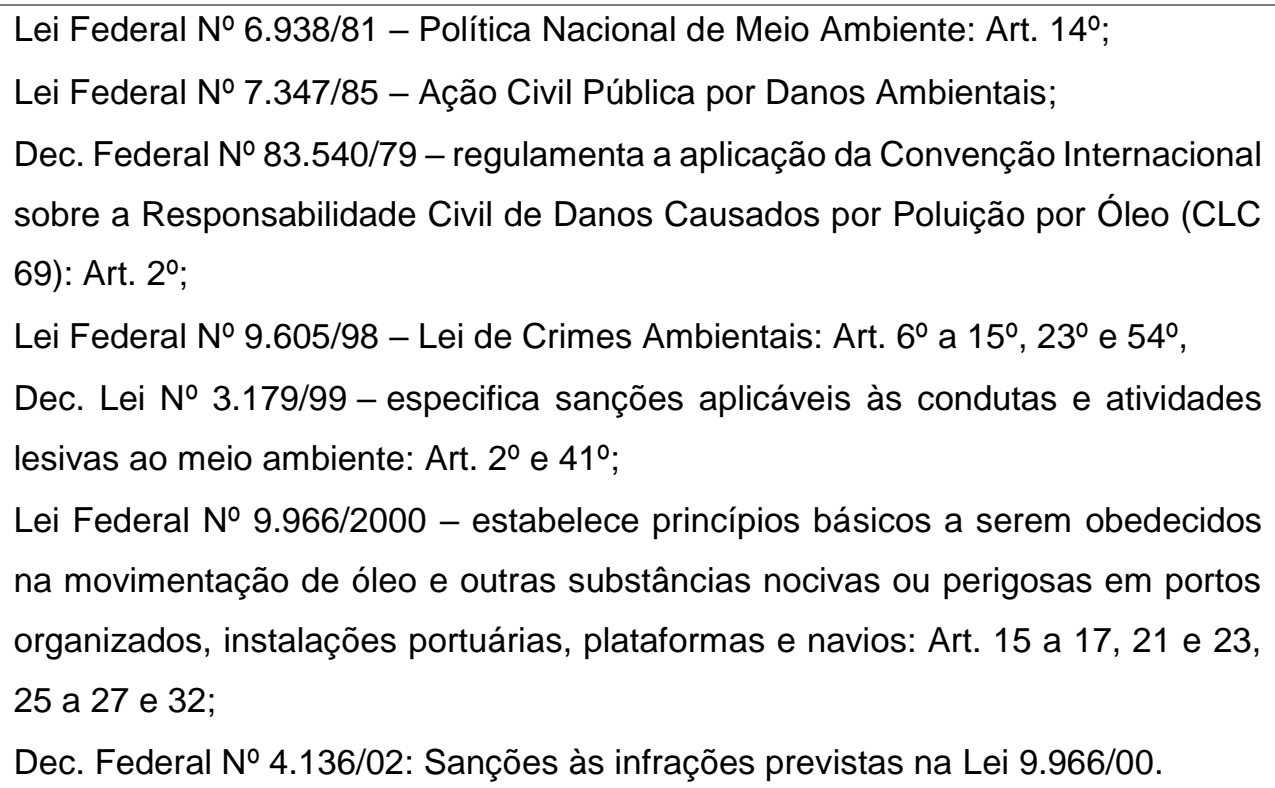 \\
\hline $\begin{array}{l}\text { Convenções } \\
\text { internacionais }\end{array}$ & $\begin{array}{l}\text { CLC } 69 \text { - Convenção Internacional sobre a Responsabilidade Civil de Danos } \\
\text { Causados por Poluição por Óleo: Dec. Federal № 83.540/79; } \\
\text { ISM Code - Código Segurança Marítima - Portaria № 046/96 da Diretoria e Portos } \\
\text { e Costas (DPC) do Ministério da Marinha; }\end{array}$ \\
\hline
\end{tabular}


MARPOL 73/78 - "Marine Pollution" - Convenção internacional para prevenção da poluição causada por navios: Dec. Executivo № 2.508/98;

OPRC 90 - Convenção Internacional sobre Preparo, Responsabilidade e Cooperação em Casos de Poluição por Óleo estabelecida pela IMO em 30/11/90: Dec. Executivo № 2.870/1998;

Convenção OPRC - HNS 2000 - Hazardous and Noxious Substances: incorporado à Lei Federal № 9.966/2000 no seu Art. 4ํ- Cap. III e IV.

Fonte - CETESB b, 2018.

Pode-se observar que a legislação ambiental brasileira está em processo de evolução. Nos últimos anos houve a criação de vários planos visando a prevenção, controle e mitigação dos acidentes envolvendo derramamento de óleo nas águas sob jurisdição nacional. Assim, o estudo e desenvolvimento de novas tecnologias e materiais para serem aplicados em casos de vazamento de óleo passam a ser, cada vez mais, questões do interesse das empresas do setor petrolífero, dos órgãos ambientais, das comunidades litorâneas e da comunidade científica (BORGES, 2015).

Neste contexto, destaca-se a importância do aprimoramento dos métodos de mitigação já disponíveis e desenvolvimento de novos materiais e métodos para reduzir os impactos gerados por derramamentos oleosos em meio aquático.

\subsection{0 petróleo}

De acordo com os dados da Agência Nacional do Petróleo (ANP, 2017a), o petróleo é um material fóssil, oleoso e inflamável, de alto valor energético, geralmente menos denso do que a água, com cheiro característico e coloração que pode variar do incolor até o preto. Extraído em terra (onshore) ou abaixo do assoalho do mar (offshore), a prospeç̧ão e sua futura exploração comercial demandam anos de preparação e grandes investimentos, que são progressivamente mais altos conforme a localização e a forma como os reservatórios se apresentam.

Por seu alto valor energético e por ser uma fonte não renovável, o petróleo se tornou um produto estratégico para o desenvolvimento das nações no mundo, com 
forte influência nas políticas internas e nas relações internacionais tanto para os países que possuem reservas como para os que não possuem.

Sua composição química é uma combinação complexa de hidrocarbonetos, podendo conter também quantidades pequenas de nitrogênio, oxigênio, compostos de enxofre e íons metálicos. A partir dele se pode obter: gás de petróleo, gás liquefeito de petróleo (GLP), nafta, gasolina, querosene, óleo diesel, óleo lubrificante, óleo combustível, resíduos como: coque, asfalto, alcatrão, breu, ceras e outros (ANP, 2017a).

No panorama mundial, o volume de petróleo produzido em 2016 aumentou em 446 mil de barris/dia (0,5\%) em relação a 2015, passando de 91,7 milhões de barris/dia para 92,2 milhões de barris/dia (figura 4). O Oriente Médio continuou como região de maior produção de petróleo, com um volume médio de 31,8 milhões de barris/dia (34,5\% do total mundial), após crescimento de 5,7\% em comparação com 2015 (ANP, 2017b).

A América do Norte veio em seguida, com produção média de 19,3 milhões de barris/dia (20,9\% do total mundial), após queda de 2,3\%. A região que compreende Europa e Eurásia ocupou do terceiro lugar, com 17,7 milhões de barris/dia (19,2\% do total mundial), após acréscimo de 1,4\%. Em seguida vieram as Américas Central e do Sul, com queda de $3,7 \%$ em sua produção de petróleo, atingindo 7,5 milhões de barris/dia ( $8,1 \%$ do total mundial).

A região Ásia Pacífico registrou queda de 4,3\% em sua produção, totalizando 8 milhões de barris/dia (8,7\% do total mundial). Por fim, veio a África, com média de produção de 7,9 milhões de barris/dia de petróleo (8,6\% do total mundial), após decréscimo de 4,9\% em relação ao ano anterior (ANP, 2017b). 
Figura 4 - Produção de petróleo, segundo regiões geográficas (milhões de barris/dia) - 2016 .

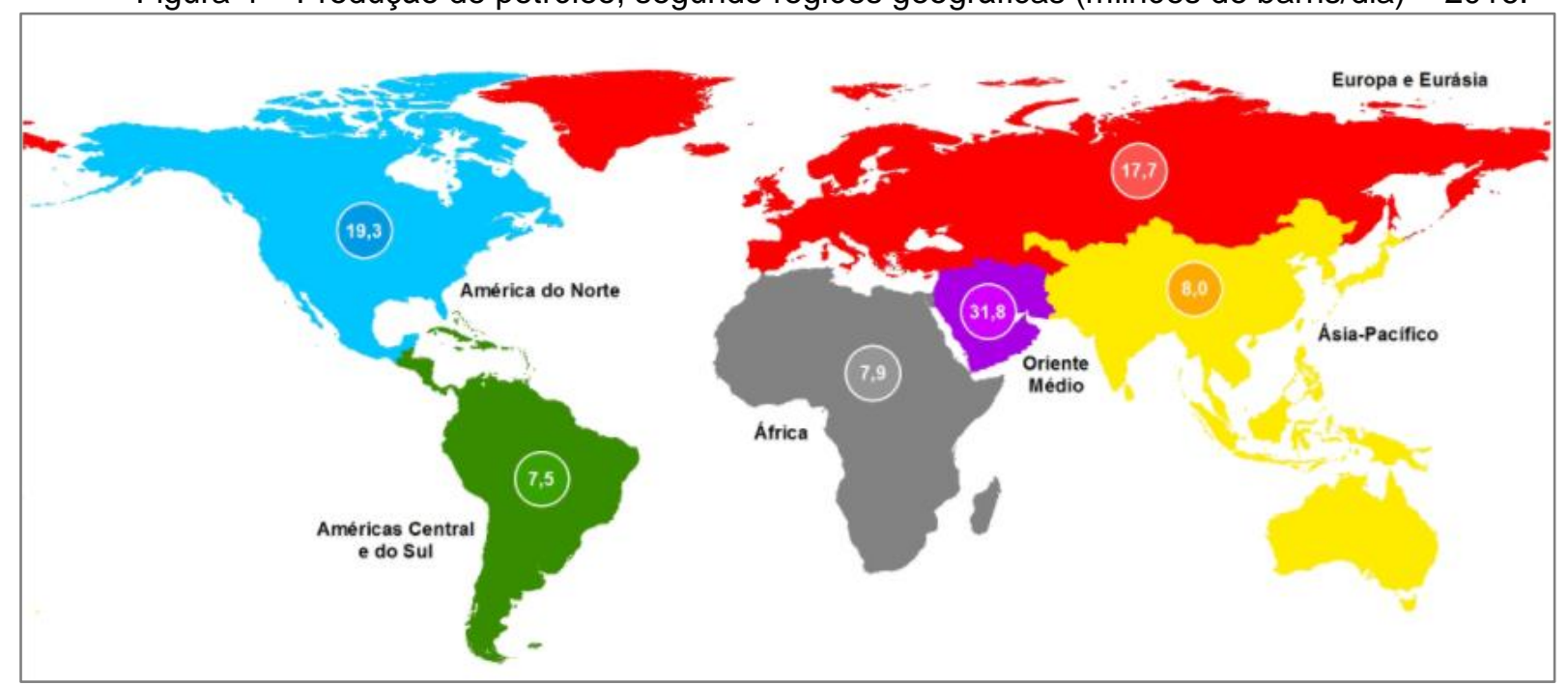

Fonte - ANP, 2017b.

No Brasil, a produção de petróleo teve início em 1941, no campo terrestre de Candeias, na Bahia. Desde então, a exploração avançou para águas rasas e profundas, que hoje representam a maior parte do volume produzido. A atual produção de petróleo ultrapassa 2,5 milhões de barris por dia em quase 300 campos. As reservas provadas aumentaram de 8,5 bilhões de barris em 2000 para 12,7 bilhões de barris em 2016 (ANP, 2017c).

Neste cenário, o Brasil figura entre os maiores usuários de combustíveis e derivados do mundo, ficando em sétimo maior consumidor em 2016, chegando a 3 milhões de barris/dia. Regionalmente, o país representou $43,3 \%$ do total consumido das Américas do Sul e Central (figura 5), e o ritmo do crescimento do consumo observado na última década foi superior à evolução de seu Produto Interno Bruto (ANP, 2017d).

Para satisfazer às necessidades de demanda, o país conta com importante infraestrutura para refino, importação, produção, especificação, movimentação e entrega para a população de derivados de petróleo, gás natural e biocombustíveis (ANP, 2017d). 
Figura 5 - Consumo de combustíveis e derivados em países selecionados da América do Sul em 2016 (mil barris/dia).

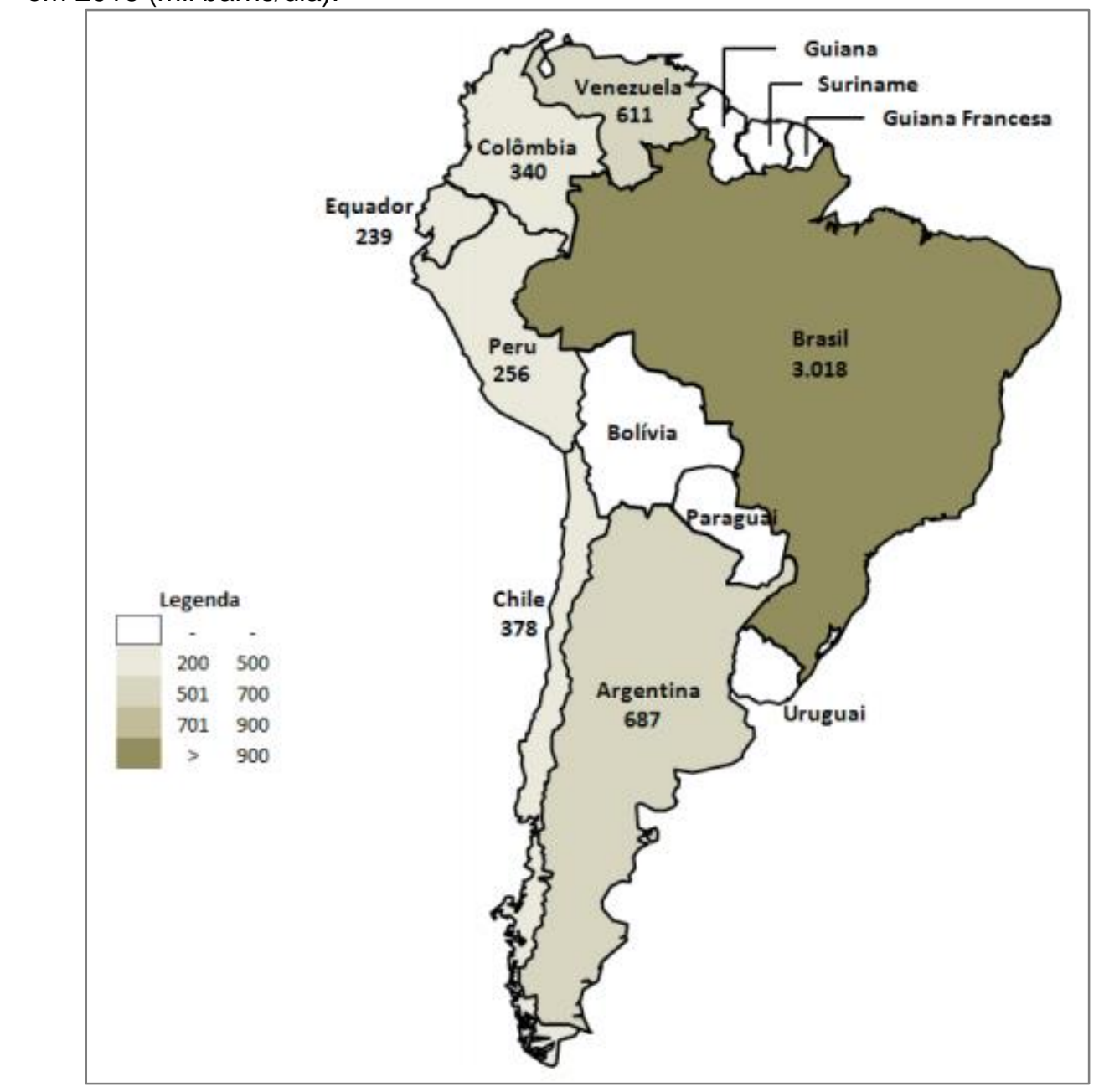

Fonte - ANP, 2017d.

\subsection{1 Óleo Diesel}

De acordo com a Confederação Nacional do Transporte (CNT, 2012), o óleo diesel é o produto oleoso mais abundante obtido a partir do refino do petróleo bruto. Sua composição apresenta, basicamente, hidrocarbonetos e, em concentrações menores, enxofre, nitrogênio e oxigênio. É um produto inflamável, com nível médio de toxicidade, pouco volátil, sem material em suspensão, límpido, com cheiro forte e característico.

É também o derivado de petróleo mais consumido no Brasil em função da predominância do transporte rodoviário, tanto de passageiros quanto de cargas. Sendo 
utilizado em motores do ciclo diesel tais como: automóveis, furgões, ônibus, caminhões, pequenas embarcações marítimas, máquinas de grande porte, locomotivas, navios e aplicações estacionárias. Sua produção ocorre durante o refino do petróleo, por meio do processo de destilação fracionada, de acordo com a faixa de temperatura (figura 6) (ANP, 2017a; CNT, 2012).

Figura 6 - Produtos derivados do petróleo.

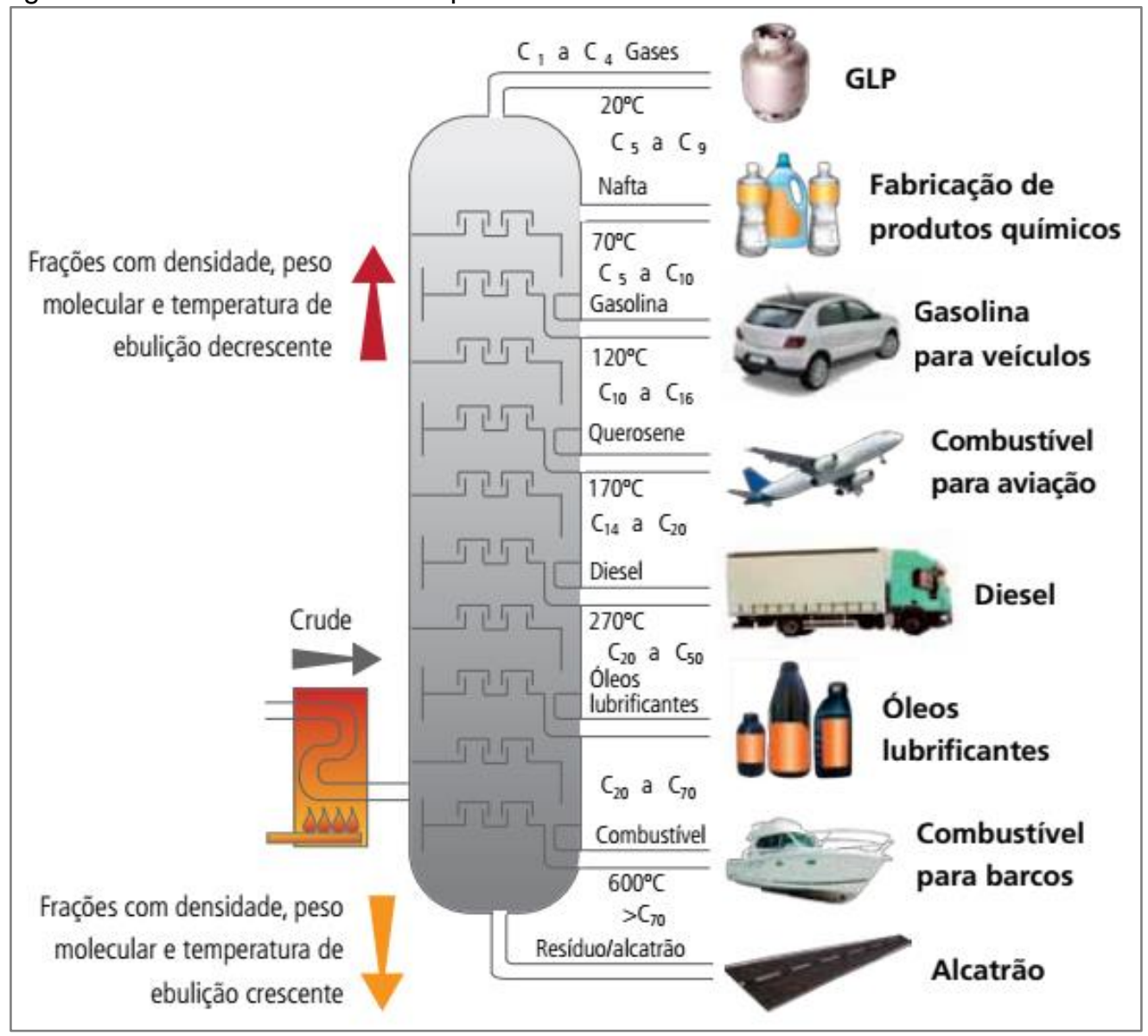

Fonte - CNT, 2012.

Um dos principais problemas relacionados à utilização do óleo diesel como combustível é o teor de enxofre nele contido. Os óxidos de enxofre, produzidos no processo de queima do enxofre, como no caso da combustão dos veículos a diesel, além de serem irritantes e tóxicos para os seres humanos também causam danos ao meio ambiente. 
O dióxido de enxofre, em contato com a umidade atmosférica, gera o ácido sulfúrico que contribui consideravelmente para a chuva ácida. A chuva ácida pode acidificar o solo e a água, fazendo com que larvas, pequenas algas, insetos não se desenvolvam. Além disso, pode provocar um arraste de metais tóxicos do solo para lagos e rios, comprometendo toda a vida aquática e contaminando os que dependem dela para sobreviver (CNT, 2012).

\subsubsection{Gasolina}

Segundo a Agência Nacional do Petróleo (ANP, 2017a), a gasolina é o segundo combustível mais consumido no Brasil. Sua composição final depende da origem do petróleo, das correntes e dos processos de produção (destilação atmosférica, alquilação, hidrocraqueamento, craqueamento catalítico, entre outros). Os hidrocarbonetos presentes na gasolina pertencem, principalmente, às classes das parafinas (normal ou ramificadas), olefinas, naftênicos e aromáticos, formados por cadeias de 4 a 12 átomos de carbono, com pontos de ebulição variando de $30 \stackrel{\circ}{\circ}$ a $215^{\circ} \mathrm{C}$.

As gasolinas comercializadas no país são do tipo A, sem etanol, vendida pelos produtores e importadores de gasolina; e tipo $\mathrm{C}$, com adição de etanol anidro, vendida aos postos revendedores e em seguida ao consumidor final.

No posto revendedor, o consumidor pode escolher entre a gasolina comum e a gasolina premium. Essa última é mais cara e, em geral, destinada a veículos de alto desempenho, pois possui um maior número de octano (ou "octanagem"), permitindo que sejam submetidas a maiores taxas de compressão no motor (ANP, 2017a).

O etanol é um combustível de produção renovável, o que é positivo ambientalmente. Desde 16 de março de 2015, o percentual obrigatório de etanol anidro combustível na gasolina comum, do tipo C, é de $27 \%$, conforme Portaria № 75 , de 5 de março de 2015, do Ministério da Agricultura, Pecuária e Abastecimento (MAPA) e Resolução № 1, de 4 de março de 2015, do Conselho Interministerial do Açúcar e do Álcool (CIMA). O percentual na gasolina premium é de 25\% (PETROBRAS, 2017). 


\subsection{Sorção, adsorção, biossorção: fenômenos interligados}

Os fenômenos adsortivos tiveram suas origens em 1773, através da observação de C. W. Scheele primeiramente em gases, subsequente em 1785 por Lowitz em soluções. Sendo considerado, um fenômeno significativo na maioria dos processos naturais físicos, químicos e biológicos. (NAJA e VOLESKY, 2011).

O termo sorção, é utilizado tanto para absorção quanto adsorção, sendo estes geralmente confundidos. A absorção é a incorporação (fixação) de uma substância (líquidos absorvidos por um sólido ou gases absorvidos pela água). A adsorção é a aderência física ou a ligação de íons e moléculas à superfície do material sólido. Neste caso, o material acumulado na interface é o adsorvato e a superfície sólida é o adsorvente (MICHALAK et al., 2013; GADD, 2008).

Numa escala molecular, o processo de sorção inicia quando o adsorvato se desloca para a camada limite do adsorvente, dentro da qual a interação eletrostática é mais forte, possibilitando maior afinidade entre ambos. Por difusão, ele se desloca aos polos do adsorvente, para, em seguida, se dirigir a um sítio onde se formam forças intermoleculares, caracterizando a sorção propriamente dita (SEGUNDO, 2011).

Rajakovic-Ognjanovic et al. (2008), descreve que a sorção, no estágio de tratamento de água, pode ser eficiente, tanto na remoção de óleo, quanto de substâncias que possuem afinidade física (fisissorção) ou química (quimissorção), por influência dos grupos ativos presentes nos sorventes.

No caso de adsorção física, a ligação do adsorvato à superfície do adsorvente envolve uma interação relativamente fraca que pode ser atribuída às forças de Van der Waalls, que são similares às forças de coesão molecular. Diferentemente, a quimissorção, a qual envolve a troca ou partilha de elétrons entre as moléculas do adsorvato e a superfície do adsorvente, ocorrendo uma reação química. Isso resulta essencialmente numa nova ligação química e, portanto, bem mais forte do que a fisissorção (NASCIMENTO et al., 2014).

Devido às suas características multifuncionais, os sorventes, também são aplicados em vários estágios do tratamento de águas residuárias oleosas, com equipamentos adicionais no tratamento. Sendo sugeridos para este setor, produtos 
minerais inorgânicos, produtos orgânicos sintéticos e/ou produtos vegetais (LEE et al., 1999).

A biossorção é uma subcategoria da adsorção, onde o sorvente é uma matriz biológica. É apresentada na literatura como um processo eficiente e seletivo que pode ser realizado em uma ampla gama de valores de $\mathrm{pH} 3$ - 9 e valores de temperatura de $4-90^{\circ} \mathrm{C}$, cujo equilíbrio é atingido rapidamente.

Este processo não exige um investimento de capital elevado, portanto, os custos operacionais são reduzidos. Além disso, os materiais biológicos são geralmente de baixo custo e podem ser obtidos da agricultura ou de resíduos industriais. (VOLESKY B, 1990 apud MICHALAK et al., 2013; NAJA e VOLESKY, 2011; GADD, 2008).

Em muitos casos, para Ribeiro (2000), a sorção de poluentes orgânicos por biossorventes, ocorre em função de algumas características do material, como, grau de hidrofobicidade, porosidade, estrutura molecular, variação do volume e área superficial.

Por esses motivos, a hidrofobicidade e a capilaridade são fatores determinantes na escolha de sorventes de óleos. Quando estes são distribuídos por uma superfície poluída, entram em contato com o material apolar e a água, desenvolvendo uma competição entre a fase polar e apolar. Devendo prevalecer molhável pelo composto hidrofóbico e, preferencialmente, não molhável ou pouco molhável pela água (RIBEIRO, 2000).

A figura 7 ilustra os mecanismos do processo de sorção em um material adsorvente. 
Figura 7 - Processo de sorção em um sólido adsorvente.

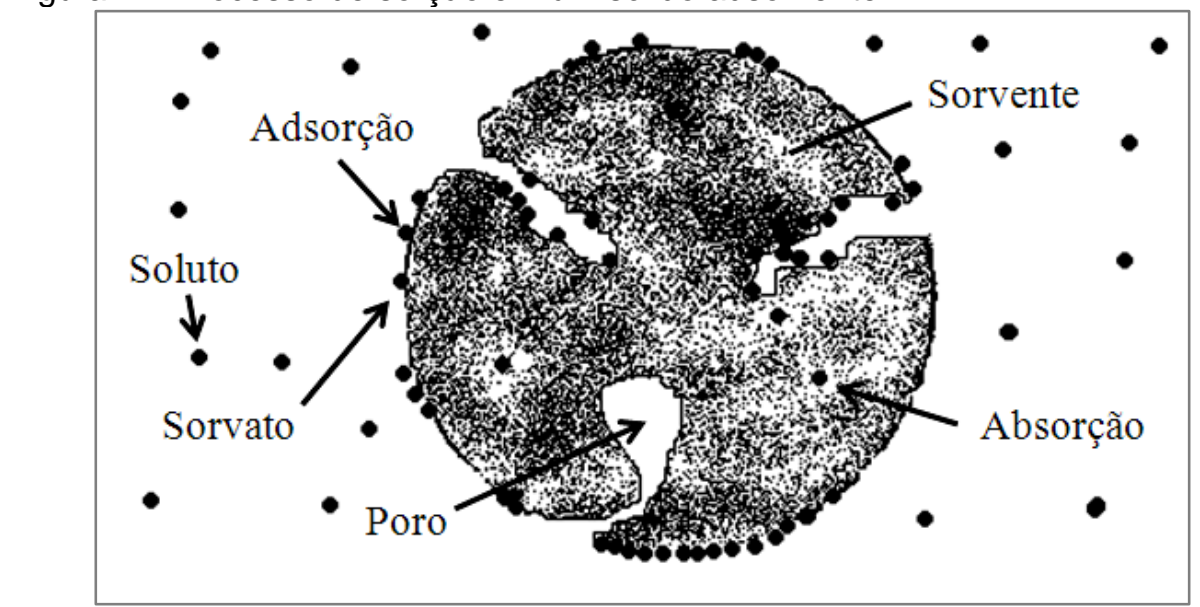

Fonte - BONETTO, 2016.

A adição de material sorvente em um derramamento de óleo facilita a mudança do óleo da fase líquida para a fase semissólida. Quando essa mudança é alcançada, é possível remover o óleo do ambiente através da remoção do sorvente (BORGES, 2015).

\subsection{Isotermas de Equilíbrio}

As isotermas de equilíbrio ou de adsorção descrevem a relação entre as concentrações na fase sólida e na fase líquida. Nascimento et al., (2014), descreve que o estado de equilíbrio em um sistema adsortivo, ocorre quando o adsorvato entra em contato com o adsorvente, assim as moléculas ou íons tendem a fluir do meio aquoso para a superfície do adsorvente até que a concentração de soluto na fase líquida $\left(\mathrm{C}_{\mathrm{e}}\right)$ permaneça constante.

Nesse estágio é dito que o sistema atingiu o estado de equilíbrio e a capacidade de adsorção do adsorvente $\left(q_{e}\right)$ é determinada. Este equilíbrio é um requisito essencial para obtenção de informações relevantes sobre o estudo e análise de um processo de separação por adsorção.

Gráficos envolvendo a capacidade de adsorção, podem ser obtidos a partir de dados experimentais. Aplicando modelagem com equações de isotermas, então a relação $q_{e}$ versus $C_{e}$ pode ser expressa na forma matemática, e a capacidade máxima 
de adsorção de um adsorvente pode ser calculada experimentalmente (COONEY, 1999 apud NASCIMENTO et al., 2014).

Dentre os tipos de isotermas, as relações mais utilizadas são as de Langmuir e Freundlich, para descrever o equilíbrio da adsorção do poluente presente na água ou em águas residuais (GEADA, 2006). Em ambos os modelos, a quantidade de soluto adsorvido por unidade de massa do adsorvente no equilíbrio, deve ser calculada pela equação 1 (SANTOS, 2015; NASCIMENTO et al., 2014).

$$
q e=\frac{V(C i-C e)}{M}
$$

Sendo: qe: quantidade de soluto adsorvido por unidade de massa do adsorvente $\left(\mathrm{mg} / \mathrm{g}^{-1}\right)$; $\mathrm{C}_{\mathrm{i}}$ : concentração inicial $\left(\mathrm{mg} / \mathrm{L}^{-1}\right)$; $\mathrm{C}_{e}$ : concentração de equilíbrio $\left(\mathrm{mg} / \mathrm{L}^{-1}\right)$; V: volume da solução (L); M: massa de adsorvente $(\mathrm{g})$.

Giles et. al., (1974), divide as isotermas em quatro principais classes de acordo com sua inclinação inicial e, cada classe, por sua vez, em vários subgrupos, baseados no formato da região superior da curva. Sendo estas, tipo S ("spherical"), L (“Langmuir"), H ("high affinity”) e C (“constant partition"), conforme tabela 2.

Tabela 2 - Classificação dos modelos de isotermas de adsorção.

\begin{tabular}{clc}
\hline \multicolumn{1}{c}{ Isoterma } & \multicolumn{1}{c}{ Característica } \\
\hline $\mathrm{S}$ & $\begin{array}{l}\text { Inclinação linear e convexa, onde a adsorção } \\
\text { inicial é baixa, porém aumenta à medida que } \\
\text { o número de moléculas adsorvidas cresce. }\end{array}$ \\
\hline ("spherical") & $\begin{array}{l}\text { Inclinação não linear e côncava, onde há } \\
\text { diminuição da disponibilidade de sítios de } \\
\text { adsorção a medida do aumento da } \\
\text { concentração da solução. }\end{array}$
\end{tabular}




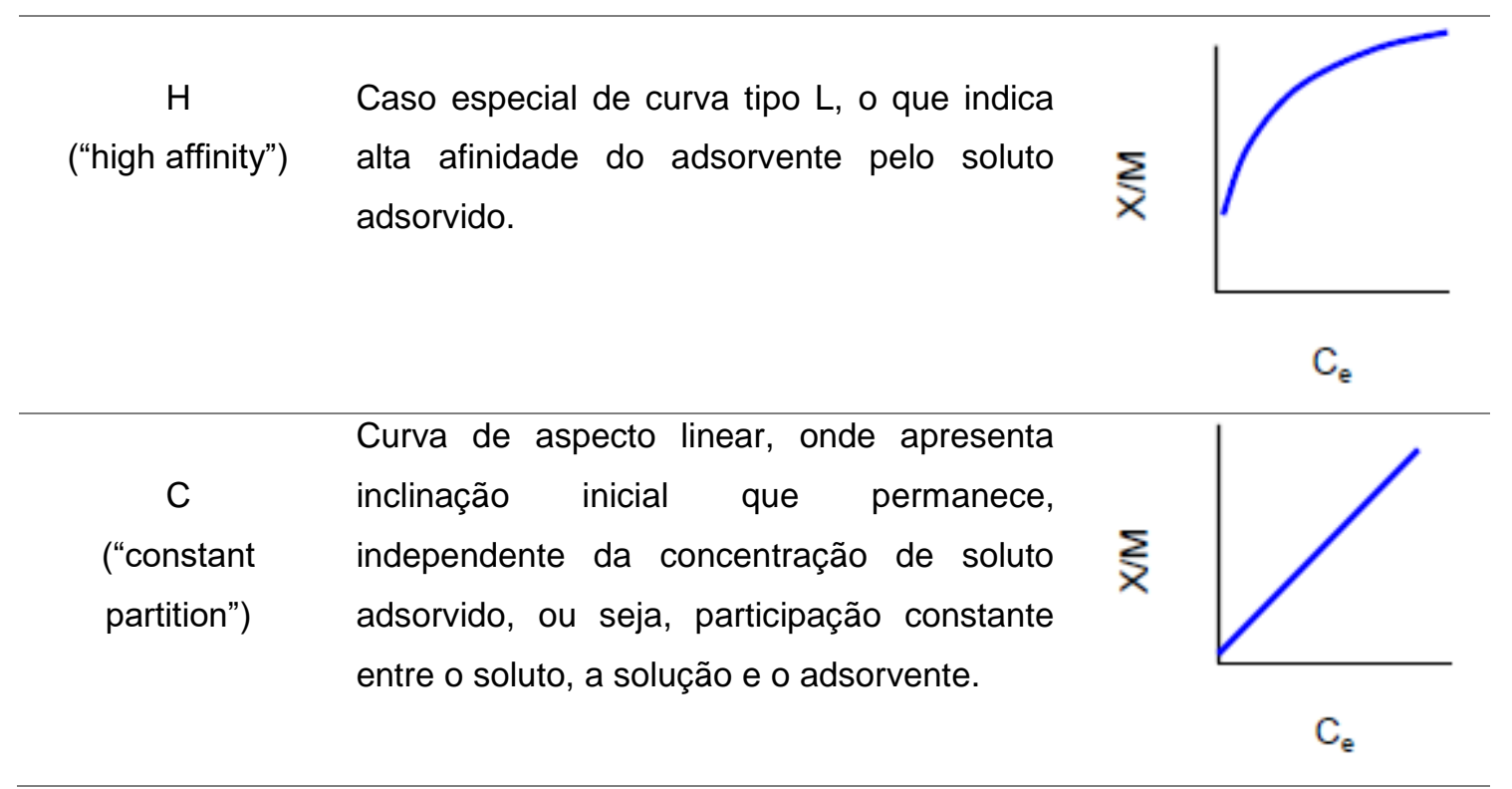

Fonte - adaptado de GILES et al., 1974.

\subsubsection{Modelos de Isotermas}

Estes modelos são fundamentais, pois possibilitam quantificar as transformações ocorridas no processo de sorção, através do cálculo da quantidade de material adsorvido, e a capacidade máxima de adsorção prevista para os materiais biossorventes estudados, dentre outras características citadas a seguir.

\subsubsection{Modelo de Langmuir}

A equação modelo de Langmuir é uma das equações mais utilizadas para representação de processos de adsorção. Essa, por sua vez, apresenta os seguintes pressupostos:

- Existe um número definido de sítios;

- Os sítios têm energia equivalente e as moléculas adsorvidas não interagem umas com as outras;

- A adsorção ocorre em uma monocamada;

- Cada sítio pode comportar apenas uma molécula adsorvida. 
A equação 2 representa a isoterma de Langmuir, e as de 3 a 6 suas formas linearizadas (LANGMUIR, 1918 apud TRAN et al., 2017).

$$
\mathrm{qe}=\frac{\mathrm{Q}_{\max } \mathrm{K}_{\mathrm{L}} \mathrm{C}_{\mathrm{e}}}{1+\mathrm{K}_{\mathrm{L}} \mathrm{C}_{\mathrm{e}}}
$$

Linearização de Hanes-Woolf (tipo 1) (TRAN et. al., 2017):

$$
\frac{\mathrm{c}_{\mathrm{e}}}{\mathrm{q}_{\mathrm{e}}}=\left(\frac{1}{\mathrm{Q}_{\max }}\right) \mathrm{C}_{\mathrm{e}}+\frac{1}{\mathrm{Q}_{\max } \mathrm{K}_{\mathrm{L}}}
$$

Linearização de Lineweaver-Burk (tipo 2) (TRAN et. al., 2017):

$$
\frac{1}{\mathrm{q}_{\mathrm{e}}}=\left(\frac{1}{\mathrm{Q}_{\max } \mathrm{K}_{\mathrm{L}}}\right) \frac{1}{\mathrm{C}_{\mathrm{e}}}+\frac{1}{\mathrm{Q}_{\max }}
$$

Linearização de Eadie-Hoffsiee (tipo 3) (TRAN et. al., 2017):

$$
\mathrm{q}_{\mathrm{e}}=\left(\frac{-1}{\mathrm{~K}_{\mathrm{L}}}\right) \frac{\mathrm{q}_{\mathrm{e}}}{\mathrm{C}_{\mathrm{e}}}+\mathrm{Q}_{\max }
$$

Linearização de Scatchard (tipo 4) (TRAN et. al., 2017):

$$
\frac{\mathrm{q}_{\mathrm{e}}}{\mathrm{C}_{\mathrm{e}}}=-\mathrm{K}_{\mathrm{L}} \mathrm{q}_{\mathrm{e}}+\mathrm{Q}_{\max } \mathrm{K}_{\mathrm{L}}
$$

Em que: qe: quantidade do soluto adsorvido por grama de adsorvente no equilíbrio ( $\mathrm{mg} \mathrm{g}^{-1}$ ); Qmax: capacidade máxima de adsorção ( $\mathrm{mg} \mathrm{g}^{-1}$ ); $\mathrm{K} \mathrm{L}$ : constante de interação adsorvato/adsorvente $\left(\mathrm{L} \mathrm{mg}^{-1}\right)$; $\mathrm{C}_{e}$ : concentração do adsorvato no equilíbrio (mg L-1). 
A transformação de dados para linearização pode resultar em modificações de estrutura de erro, introdução de erro no independente variável, e alteração do peso colocado em cada dado ponto, que muitas vezes leva a diferenças nos parâmetros e valores entre as versões linear e não linear do modelo Langmuir (TRAN et al., 2017).

Para a linearização tipo 1, C e e Ce/qe não são independentes, a correlação entre eles é superestimada, isto é, esta equação pode fornecer bons ajustes aos dados que não estão em conformidade com o modelo de Langmuir.

Para a linearização tipo 2, a transformação leva ao agrupamento de pontos de dados perto da origem, e é extremamente sensível à variabilidade em valores baixos de $q_{e}$ (valores altos de $1 / q_{e}$ ).

Para a linearização tipo 3, a abscissa não é livre de erros, e qe/ $\mathrm{C}_{e}$ e qe não são independentes. Assim, a correlação entre eles é subestimada, isto é, esta equação se encaixa nos dados que se ajustam ao modelo de Langmuir.

Para a linearização tipo 4 , as variáveis $q_{e}$ e $q_{e} / C_{e}$ também não são independentes na linearização. Neste caso, a correlação entre eles é subestimada, ou seja, esta equação pode fornecer um ajuste inadequado aos dados que se conformam ao modelo de Langmuir (TRAN et al., 2017).

\subsubsection{Modelo de Freundlich}

A isoterma proposta por Freundlich foi uma das primeiras a equacionar a relação entre a quantidade de material adsorvido e a concentração do material na solução em um modelo com características empíricas. Este modelo empírico pode ser aplicado a sistemas não ideais, em superfícies heterogêneas e adsorção em multicamada.

O modelo considera o sólido heterogêneo, ao passo que aplica uma distribuição exponencial para caracterizar os vários tipos de sítios de adsorção, os quais possuem diferentes energias adsortivas (NASCIMENTO et al., 2014; BONIOLO, 2008).

A equação 7 representa a isoterma de Freundlich e a 8 sua forma linearizada (TRAN et al., 2017):

$$
q e=K_{F} C e^{n}
$$




$$
\log q_{e}=n \log C_{e}+\log K_{F}
$$

Em que: qe: quantidade de soluto adsorvido ( $\left.\mathrm{mg} \mathrm{g}^{-1}\right)$; $\mathrm{C}_{\mathrm{e}}$ : concentração de equilíbrio em solução ( $\left.\mathrm{mg} \mathrm{L}^{-1}\right)$; $\mathrm{n}$ : constante relacionada à heterogeneidade da superfície; sendo menor do que 1, diz-se que a adsorção é um processo favorável; $\mathrm{K}_{\mathrm{F}}$ : constante de capacidade de adsorção de Freundlich $\left(\mathrm{mg} \mathrm{g}^{-1}\right)\left(\mathrm{L} \mathrm{mg}^{-1}\right)^{\mathrm{n}}$.

\subsection{Cinética de sorção}

A cinética de sorção é expressa como a taxa de remoção do adsorvato na fase fluida em relação ao tempo. Envolve a transferência de massa de um ou mais componentes contidos em uma fase fluida, para o interior de partículas adsorventes, os quais deverão migrar através dos macroporos até regiões mais interiores desta partícula. Em princípio, esta cinética pode ser conduzida por:

- Transferência de massa externa: a qual corresponde a transferência de moléculas da fase fluida para superfície externa da partícula adsorvente, por intermédio de uma camada de fluido que envolve a partícula;

- Difusão no poro: a qual é ocasionada pela difusão de moléculas no fluido para o interior dos poros;

- Difusão na superfície: a qual corresponde à difusão das moléculas totalmente adsorvidas ao longo da superfície do poro.

O processo adsortivo pode ser influenciado por alguns fatores, como a agitação e a concentração do adsorvato. Neste caso, um aumento da concentração do soluto, pode acelerar a difusão dos mesmos da solução para a superfície do sólido. A velocidade do sistema também pode ser alterada pela temperatura, $\mathrm{pH}$, força iônica, concentração inicial do adsorvato, tamanho das partículas e distribuição do tamanho dos poros (NASCIMENTO et al., 2014; FERREIRA, 2014; HUBBE et al., 2013; BONIOLO, 2008).

Para Ribeiro (2000), a adsorção de não eletrólitos, nos modelos mais difundidos, é restrita a uma monocamada próxima da superfície. A intensidade das interações adsorvato/adsorvente decai rapidamente com a distância, similarmente a 
quimissorção de gases. O calor de adsorção sólido/líquido em sistemas com não eletrólitos é usualmente pequeno, sendo comparável ao calor de solução e não tendo relação quantitativa com calores típicos de ligações químicas.

Para este mesmo autor, na maioria dos casos há uma combinação de diversas formas de adsorção, isto é, várias forças diferentes que influenciam os diversos tipos de adsorção, frequentemente somam seus efeitos para provocar a concentração de um soluto particular em uma interface. E, assim, muitos processos de adsorção envolvendo moléculas orgânicas resultam de interações específicas entre elementos estruturais do sorvato e do sorvente. Estas interações podem ser designadas como adsorção específica.

A interação atrativa entre moléculas apolares, tais como hidrocarbonetos, em água é conhecida como sendo particularmente forte. Esta interação hidrofóbica pertence a uma classe de importantes fenômenos, denominados como efeito hidrofóbico. Este efeito é responsável pelos valores de tensão interfacial nas superfícies água/hidrocarboneto, e pelos grandes ângulos de contato apresentados pela água sobre superfícies hidrofóbicas (RIBEIRO, 2000).

Dependendo da natureza das moléculas do solvente e da superfície, existem forças repulsivas ou atrativas, sendo elas hidrofóbicas ou hidrofílicas. As forças hidrofóbicas promovem a atração de longo alcance, entre superfícies hidrofóbicas, sendo esta considerada, em termos de energia de coesão, como da ordem das ligações por pontes de hidrogênio. Ainda, pelo fato de serem consideradas pelo "reconhecimento" molecular, estas forças devem ser responsáveis pela sorção de óleos e compostos orgânicos por substratos hidrofóbicos (MARTINS et al., 2013; RIBEIRO, 2000).

\subsubsection{Ligações de hidrogênio, estrutura da água e o efeito hidrofóbico}

As ligações de hidrogênio podem desempenhar papel importante na propagação de óleo em substratos úmidos, particularmente no caso de sorventes celulósicos. Isto porque os materiais celulósicos têm uma capacidade substancial de formar ligações de hidrogênio na sua interface com a fase aquosa. Em contraste, as 
moléculas apolares no óleo não podem formar ligações de hidrogênio na interface com a água. Essa diferença ajuda a explicar por que quantidades menores de sorção de óleo às vezes foram observadas em fibras celulósicas úmidas em comparação com fibras secas do mesmo tipo (PAYNE et al., 2012).

As substâncias apolares em meio aquoso induzem mudanças na estrutura da água. No caso, as moléculas de água se rearranjam em torno do soluto para maximizar o número de ligações de hidrogênio (figura 8). Esta mudança na estrutura da água é o princípio para o efeito hidrofóbico que impulsiona a automontagem de entidades apolares em meio aquoso (MEYER et al., 2006). No geral, pode-se afirmar que a ligação de hidrogênio é um fator importante em sistemas aquosos que transportam solutos (CLAESSON et al., 2006).

Embora cada unidade de piranose de uma macromolécula de celulose ou hemicelulose contenha três grupos - $\mathrm{OH}$, apenas uma fração de tais grupos está disponível para participar na ligação de hidrogênio com uma fase aquosa sob condições comuns (MANN e MARRINAN, 1958; KADLA e GILBERT, 2000). Como consequência, uma superfície celulósica típica não é totalmente hidrofílica (BIERMANN et al., 2001). De fato, certas faces de celulose cristalinas podem na verdade ser consideradas hidrofóbicas (YAMANE et al., 2006).

Figura 8 - Organização de camadas ou "gaiolas" de água em torno de compostos hidrofóbicos.

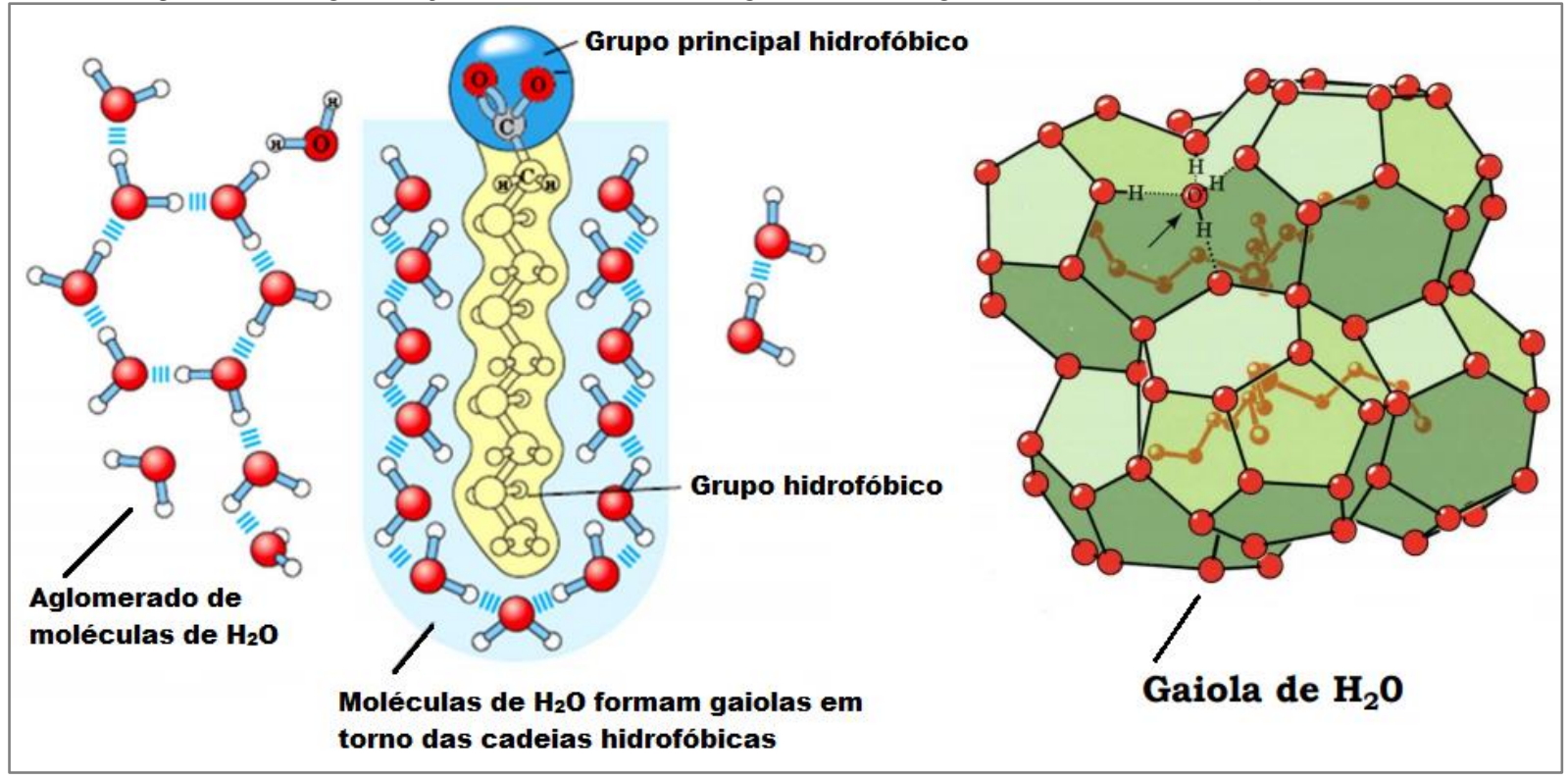


Fonte - Adaptado de Google Imagens, 2018.

\subsection{Fibras vegetais}

As fibras vegetais usualmente são designadas como materiais lignocelulósicos. Algumas ocorrem espontaneamente na natureza, outras são cultivadas como atividade agrícola e ainda há aquelas que são resíduos gerados, principalmente, pela agroindústria (BORGES, 2015).

Farinas (2011), descreve em sua pesquisa, que a parede celular vegetal é composta por uma mistura de polissacarídeos, proteínas, compostos fenólicos e sais minerais. Os polissacarídeos representam cerca de $90 \%$ do peso seco da parede e consistem em celulose, que compõe de 20 a $40 \%$ da parede celular, hemiceluloses (15-25\%) e pectinas ( 30\%).

Essa matriz é altamente ordenada e dinâmica podendo tornar-se mais rígida ou mais flexível conforme as necessidades da planta. Além dos polissacarídeos, a parede celular é também impregnada pela lignina, um polímero aromático que fornece rigidez a planta, conforme ilustrado na figura 9.

Figura 9 - Complexos lignocelulósicos: cadeias de celulose envolvidas por hemicelulose e lignina.

\section{LIGNINA}

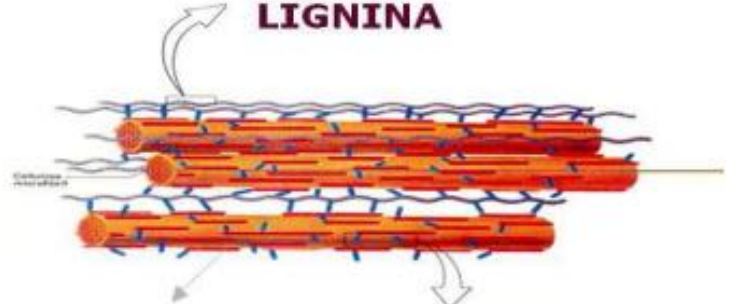

CELULose HeMicelulose

Fonte - OGATA, 2013.

Quanto a classificação, as fibras vegetais podem ser agrupadas em cinco categorias, dependendo da parte e do tipo de vegetal do qual foi retirada, sendo estas: (ANNUNCIADO, 2005).

- Fibras de Gramíneas: retiradas das hastes das plantas monocotiledôneas, tendo como exemplo os cereais (trigo, aveia, cevada, arroz e outros). Junco, bambu e bagaço-de-cana; 
- Fibras de Folhas: retiradas ao longo do comprimento das folhas, exemplos típicos incluem a abacá, sisal e henequém;

- Fibras de Caule: São de maços retirados do interior da casca (caule) de hastes de plantas, tendo como exemplos, linho, juta, cânhamo e kenaf;

- Fibras de Sementes e Frutos: Os exemplos mais comuns são o algodão, a paina e a esponja de Luffa cylindrica;

- Fibras de Madeiras: São fibras provenientes do xilema de vegetais (angiospermas e gimnospermas). Exemplos incluem os eucaliptus, abetuos, pinus, entre outros.

A grande disponibilidade destas fibras, somada ao interesse na substituição de materiais poliméricos por materiais de fonte renovável, tem impulsionado o desenvolvimento de diversas pesquisas utilizando fibras vegetais como sorventes (BORGES, 2015; SANTOS, 2015; FERREIRA, 2014; OLIVEIRA, 2010; BONIOLO, 2008; GADD, 2008; ANNUNCIADO, 2005; RIBEIRO, 2000; LEE et al., 1999).

\subsubsection{Celulose}

A celulose $\left(\mathrm{C}_{6} \mathrm{H}_{10} \mathrm{O}_{5}\right)_{n}$ é o principal componente da parede celular dos vegetais. Ela apresenta a mesma estrutura em todos os tipos de biomassa, mudando apenas pelo grau de polimerização (BENEVIDES, 2015).

Um dos principais componentes da parede celular, a celulose, é um homopolissacarídeo não ramificado constituído unicamente por moléculas de glicose unidas entre si por ligações glicosídicas do tipo $\beta-1,4$. Duas unidades de glicose adjacentes formam uma ligação glicosídica através da eliminação de uma molécula de água (figura. 10). Devido à configuração espacial alternada das ligações glicosídicas, a unidade de repetição da celulose é a celobiose, um dissacarídeo (FARINAS, 2011; CARVALHO W. et al., 2009).

A celobiose, contém grupos hidroxila que estabelecem interações do tipo ligações de hidrogênio intra e intermolecular. Devido a essas ligações de hidrogênio, há uma forte tendência de a celulose formar cristais (figura 11) que as tornam 
completamente insolúvel em água e na maioria dos solventes orgânicos (BORGES, 2015).

Figura 10 - Moléculas de glicose unidas entre si por ligações glicosídicas do tipo $\beta-1,4$, mostrando o sistema de numeração dos carbonos e a configuração da ligação glicosídica.

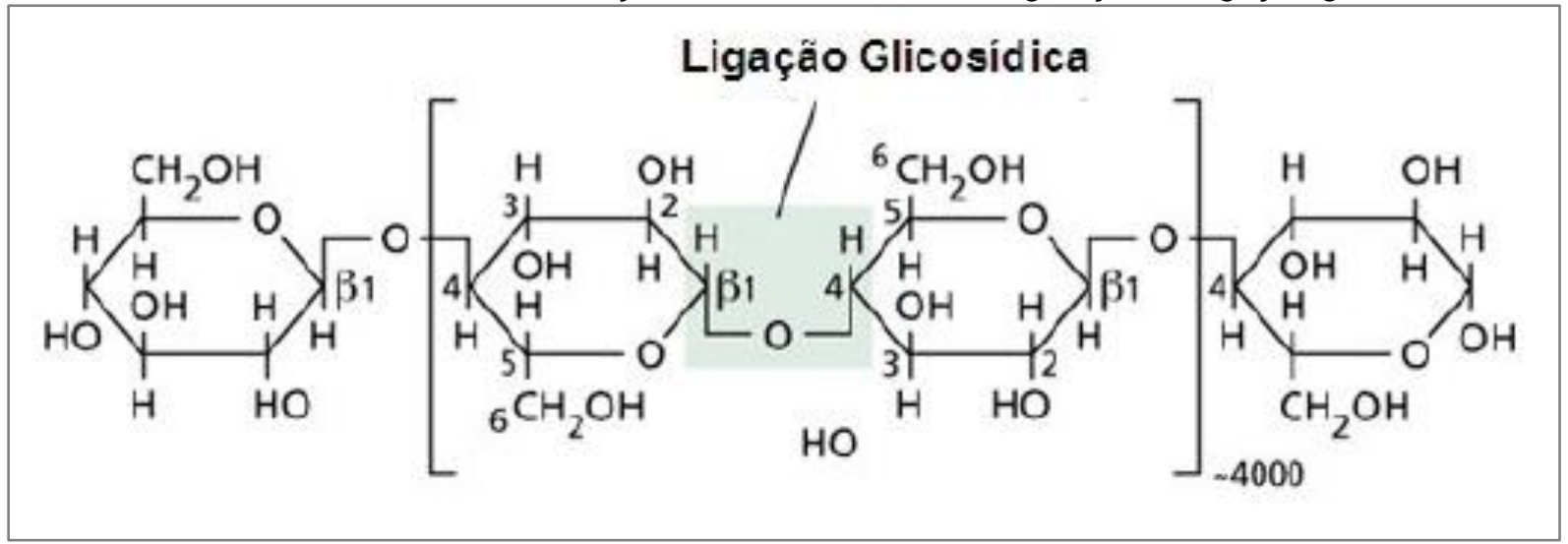

Fonte - FARINAS, 2011.

Figura 11 - Estrutura da celulose destacando as regiões cristalinas e amorfas.

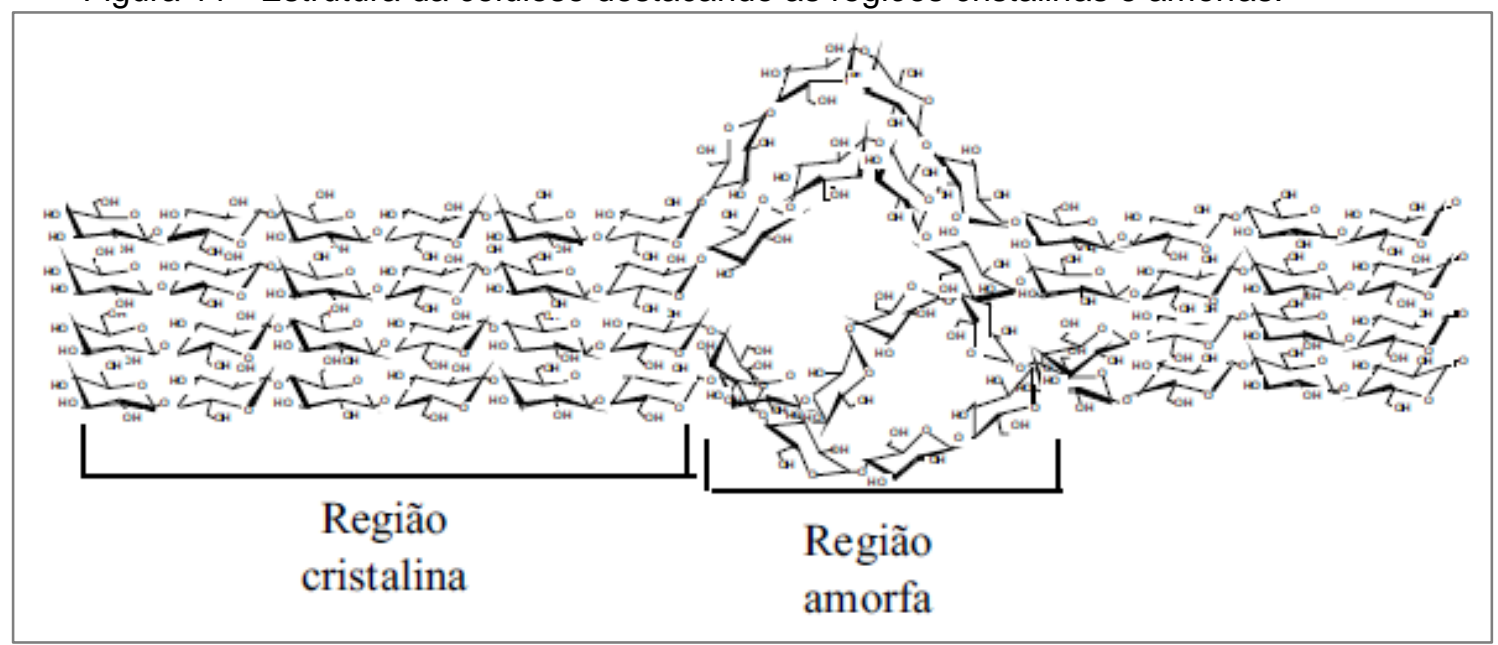

Fonte - FARINAS, 2011.

\subsubsection{Hemicelulose}

As hemiceluloses ou também chamadas de polioses, são heteropolissacarídeos formados por vários resíduos de açúcares pentoses (xilose e arabinose) e hexoses (glicose, manose e galactose), ácidos urônicos e grupos acetila. Esses açúcares estão ligados entre si, principalmente por ligações glicosídicas $\beta-1,4$, formando uma 
estrutura principal composta por um tipo específico de resíduo, a partir da qual surgem ramificações laterais de cadeias curtas de outros compostos (figura 12 e 13) (FARINAS, 2011; CARVALHO W. et al., 2009).

Figura 12 - Carboidratos que compõe as unidades de hemicelulose.

(n)

Fonte - OGATA, 2013.

Figura 13 - Estrutura típica da hemicelulose mostrando as diferentes ligações e compostos encontrados nas ramificações.

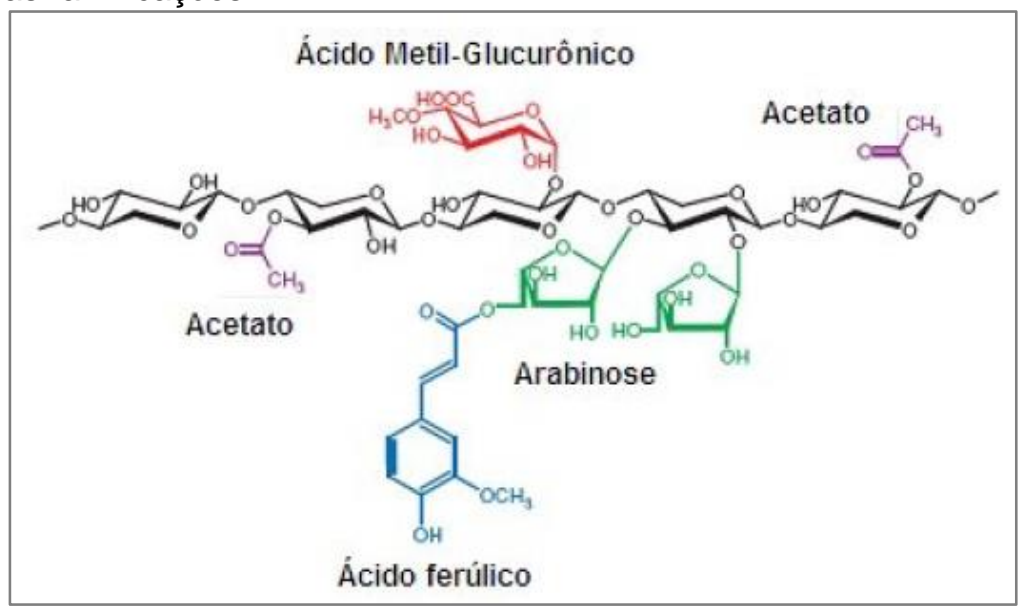

Fonte - FARINAS, 2011. 
De acordo com Tibola (2014), sua composição química e características estruturais variam conforme a espécie da planta, estágio de desenvolvimento, localizações subcelulares e tipo de tecido. Deste modo, várias subclasses de hemiceluloses podem ser encontradas, como as xiloglicanas e $\beta$-glicanas, que possuem um importante papel na estrutura e função da parede celular, pois estão envolvidas no suporte e reticulação da matriz celulósica através de ligações de hidrogênio com a celulose e outras hemiceluloses.

Elas apresentam uma estrutura de natureza amorfa, contém considerável grau de ramificação entre suas cadeias, possuem baixo peso molecular e são bastante hidrofílicas, o que facilita a absorção de água e contribui para o intumescimento e flexibilidade das fibras. Estas se encontram intercaladas às microfibras de celulose e atuam como um elemento de ligação entre a celulose e a lignina, tornando-se um componente estrutural da parede celular de plantas. (TIBOLA, 2014; OGATA, 2013).

\subsubsection{Lignina}

Conforme Benevides (2015), a lignina é um polímero tridimensional amorfo encontrado nas plantas terrestres, associado à celulose na parede celular formando um complexo lignocelulósico, cuja função é de conferir rigidez, impermeabilidade e resistência a ataques microbiológicos e mecânicos aos tecidos vegetais.

As ligações éteres dominam a união entre as unidades da lignina, que apresenta muitas interligações. Esta resina amorfa atua como matriz entre as fibrilas e como um agente enrijecedor no interior das fibras. A força de adesão entre as fibras de celulose e lignina é ampliada pela existência de ligações covalentes entre as cadeias de lignina e os constituintes da celulose e da hemicelulose (BORGES, 2015).

As unidades monoméricas precursoras da lignina são hidroxilas fenólicas dos álcoois p-cumarílico, coniferílico e sinapílico (OGATA, 2013; FARINAS, 2011), cuja representação química pode ser observada na figura 14. 
Figura 14 - Monômeros precursores da lignina.

Fonte - OGATA, 2013.

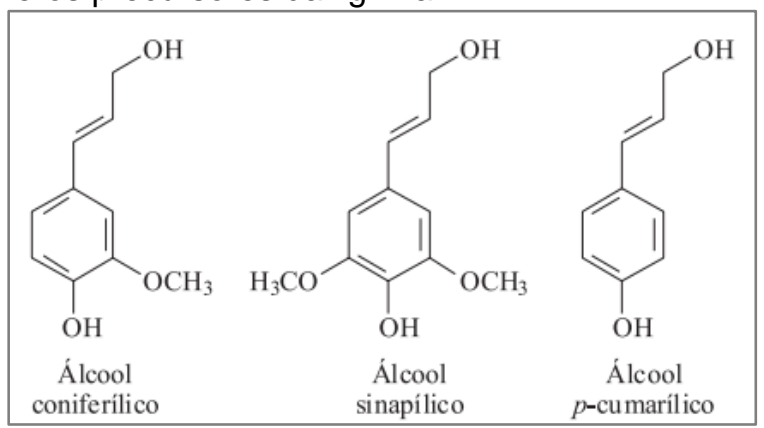

3.6.4 Ativação dos biossorventes através da modificação química

A modificação química dos biossorventes pode ser feita em solução alcalina de hidróxido de sódio, ela age nas fibras de celulose solubilizando os grupos - $\mathrm{OH}$ (FONSECA, 2015).

Durante esse processo, o material expande-se e as cadeias de polissacarídeos são rearranjadas (figura 15). A quantidade de material menos ordenado aumenta, enquanto a parte cristalina diminui. Assim, os grupos hidroxila das macromoléculas de celulose tornam-se mais facilmente acessíveis.

Isso acarreta alteração na estrutura e morfologia das fibras, produzindo mudanças na resistência e no brilho, bem como nas suas propriedades de adsorção, além de torna-las mais hidrofóbicas (FERREIRA, 2014; HUBBE et. al., 2013; GURGEL, 2007).

Figura 15 - Efeito da modificação química nos biossorventes.

Fonte - adaptado de FONSECA, 2015.

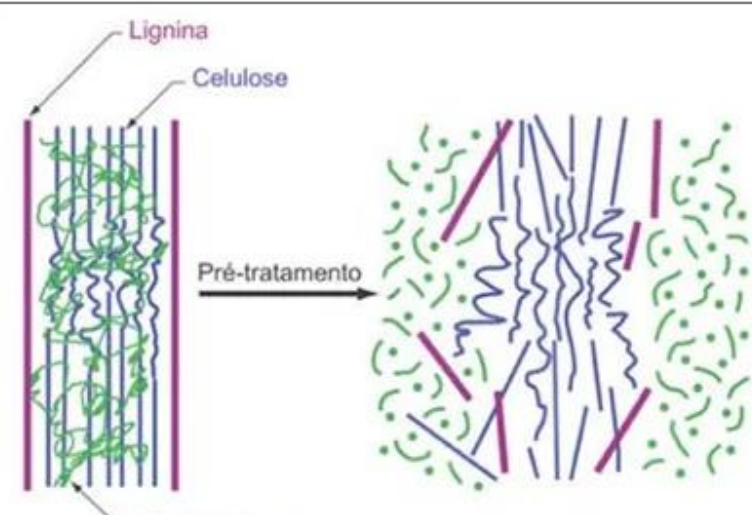




\subsubsection{Banana}

A banana é a fruta predileta dos brasileiros, a quase totalidade da produção é absorvida pelo mercado interno. A facilidade de acesso também contribui para os altos índices do consumo, uma vez que é encontrada em todo e país. A predileção pode ser constatada nos números, uma vez que em torno de $99 \%$ da produção nacional abasteceu o mercado interno em 2016 (CARVALHO C. et al., 2017).

Apesar de não ser autóctone, o cultivo da banana no Brasil se espalhou de tal maneira que hoje se destaca como a fruta mais consumida no país. É ingerida crua, assada, frita, em farinha, em purê, em passas, em compotas, transformada em licor ou aguardente. Suas origens são predominantemente do sudeste asiático, nas regiões que hoje compreendem Filipinas, Malásia e Indonésia (BORGES, 2015).

No ranking mundial, a Índia lidera a produção de bananas, sendo responsável por $28,1 \%$. A China, com $10,1 \%$, vem em segundo lugar, seguida pelas Filipinas, com 8,6\%; Equador, com 7\%; Brasil, com 6,9\%; e Indonésia, com 5,8\% (VIEIRA, 2015).

De acordo com dados do IBGE, para produção de banana a nível nacional, em 2017 foram em média 486 mil ha de área cultivada; 7,1 milhões de toneladas de produção, destacando-se as regiões Sudeste e Nordeste como maiores produtores (tabela 3); e 14,6 mil kg/ha de rendimento. Nos últimos dez anos a produção anual média em área plantada foi de 500 mil ha, a produção anual média obtida de 7 milhões de toneladas e o rendimento anual médio de 14,2 mil Kg/ha (IBGE, 2018).

Tabela 3 - Produção de bananas (mil toneladas) em 2018, por região do Brasil.

\begin{tabular}{ll}
\hline Sudeste & 2400 \\
\hline Nordeste & 2320 \\
\hline Sul & 1100 \\
\hline Norte & 1000 \\
\hline Centro Oeste & 300
\end{tabular}

Fonte - IBGE, 2018.

A casca da banana representa de 47 a $50 \%$ do peso total da fruta madura (figura 16), e não tem aplicações de ordem industrial, sendo esporadicamente utilizada de forma direta, na alimentação animal (CRUZ, 2009). 
Figura 16 - Fruto da banana para consumo (A) e suas cascas (B).

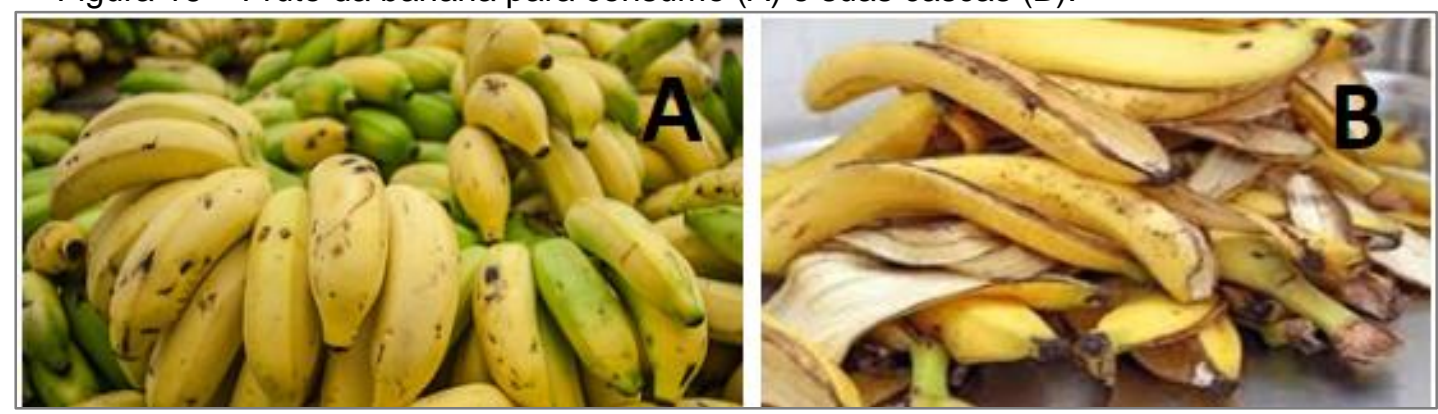

Fonte - GOOGLE IMAGENS, 2018.

Devido à grande quantidade de resíduo das cascas, este material tem sido objeto de estudo para sua reciclagem. A biossorção é um deles, podendo ser empregada na retenção de íons em soluções aquosas, no tratamento de efluentes industriais contaminados com metais tóxicos, corantes e derramamento oleosos (SILVA et al., 2016; BORGES, 2015; COSTA et at., 2012; BELISÁRIO et al., 2010; CRUZ, 2009; BONIOLO, 2008).

\subsubsection{Coco}

Para Martins e Jesus Jr. (2014), o coqueiro é considerado uma planta de múltiplas funcionalidades, virtuosamente pela gama de produtos que podem ser explorados, levando ao reconhecimento mundial como um recurso vegetal vital para toda a humanidade. Encontra-se difundida em praticamente todos os continentes, sendo encontrada em mais de 200 países. Sua exploração comercial se detém expressivamente em aproximadamente 90 países, onde se encontram os maiores plantios e melhores condições de cultivo.

A maior parte da área plantada com coqueiros no mundo situa-se na Ásia, principalmente na Índia, Filipinas, Indonésia, Sri Lanka e Tailândia, correspondendo a aproximadamente $70 \%$ da área mundial, enquanto que o restante se distribui nos continentes da África, América Latina, Oceania e Caribe. A Indonésia se destaca como o maior produtor mundial de coco, seguido por Filipinas e Índia. Em termos de produtividade, o Brasil lidera o ranking dos países com maior rendimento (MARTINS e JESUS JR., 2014).

De acordo com dados do IBGE, para produção de coco, a nível nacional, em 2017 foram em média 241 mil ha de área cultivada; 1,7 milhões de toneladas de 
produção, destacando-se a região Nordeste como maior produtor (tabela 4); e 7,2 mil $\mathrm{kg} / \mathrm{ha}$ de rendimento. Nos últimos dez anos a produção anual média em área plantada foi de 270 mil ha, a produção anual média obtida foi de 2 milhões de toneladas e o rendimento anual médio de 7,3 mil $\mathrm{Kg} / \mathrm{ha}$.

Tabela 4 - Produção de coco (mil toneladas) em 2018, por região do Brasil.

\begin{tabular}{ll}
\hline Nordeste & 1280 \\
\hline Sudeste & 220 \\
\hline Norte & 218 \\
\hline Centro Oeste & 18 \\
\hline Sul & 2 \\
\hline
\end{tabular}

Fonte - IBGE, 2018.

A maioria dos países que cultivam essa palmeira as utiliza para produção de frutos, com os objetivos de explorarem comercialmente a copra para produção de óleo e coco seco desidratado. No Brasil, o coqueiro é cultivado com a finalidade de produzir frutos destinados à agroindústria para produção principal de coco ralado e leite coco, além da água de coco.

Esse segmento de água de coco tem crescido nos últimos anos, apresentando ainda grandes perspectivas futuras, tendo em vista o crescimento do consumo nos mercados interno e externo, o qual, tem sido normalmente associado à qualidade de vida e saúde (MARTINS e JESUS JR., 2014).

A casca do coco, subproduto do consumo e da indústria, tem se tornado um problema ambiental nos grandes centros urbanos (figura 17 e 18). É um material de difícil decomposição, levando mais de oito anos para se decompor. Assim, a utilização desta casca processada, além da importância econômica e social, é também interessante do ponto de vista ambiental. Cerca de $85 \%$ do peso bruto do coco é considerado resíduo (SEBRAE, 2017). 
Figura 17 - Coco verde destinado ao consumo de água $(A)$ e de coco seco destinado a processamento industrial (B).

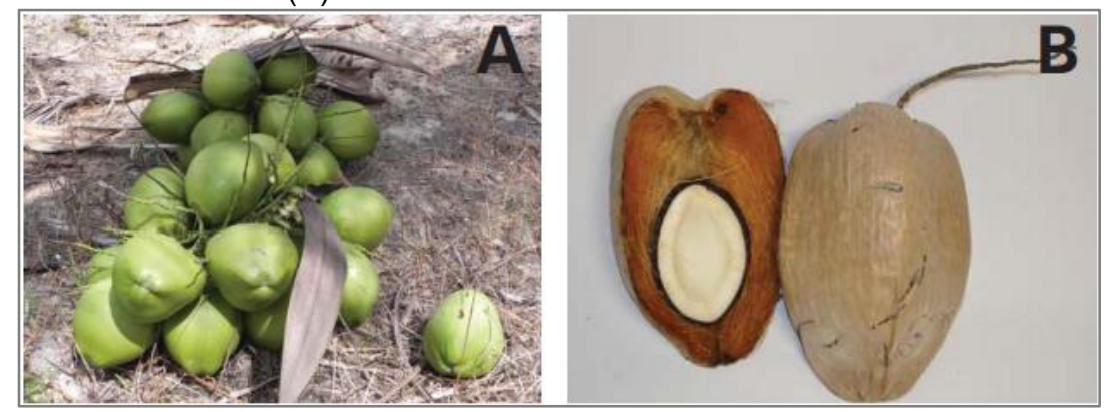

Fonte - MARTINS e JESUS JR., 2014.

Figura 18 - Diferenciação dos elementos do coco.

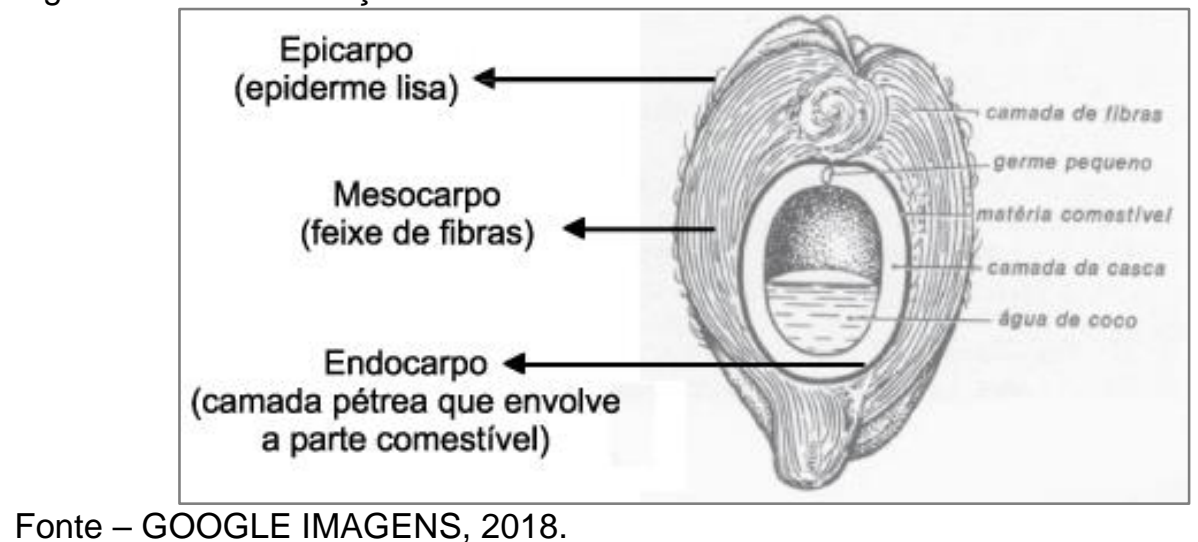

As fibras do coco podem ser utilizadas na agricultura e na indústria, para fabricação de cordas, tapetes, encostos de veículos, entre outros, elas são quase inertes e possuem alta porosidade (SEBRAE, 2017). Na área científica estas fibras vêm sendo amplamente estudadas, já que suas propriedades são vastas principalmente como reforço de materiais compósitos e como biossorvente (FONSECA, 2015; JESUS, 2013; BARBOSA et al., 2011; OLIVEIRA, 2010; MONTEIRO 2009; ANNUNCIADO, 2005).

\subsubsection{Laranja}

De acordo com Carvalho C. et. al., (2017) e dados estatísticos do IBGE (2018), a laranja é a principal fruta produzida e comercializada no Brasil, que é líder mundial, junto com o suco da fruta. Cerca de $97 \%$ da produção de suco é destinada ao exterior, sendo os principais consumidores a União Europeia, seguido dos Estados Unidos, que 
é o segundo grande produtor mundial dessa fruta. O Brasil também responde por cerca de $70 \%$ do total comercializado e tem conseguido manter os níveis de exportação, com elevação de 4\% entre os anos de 2015 e 2016.

Para produção de laranja, a nível nacional, em 2017 foram em média 641 mil ha de área cultivada; 17,4 milhões de toneladas de produção, destacando-se a região Sudeste como maior produtor (tabela 5); e $27 \mathrm{mil} \mathrm{kg} / \mathrm{ha}$ de rendimento para o ano de 2017. Nos últimos dez anos a produção anual média em área plantada foi de 780 mil ha, a produção anual média obtida foi de 18 milhões de toneladas e o rendimento anual médio de 24 mil Kg/ha (IBGE, 2018).

Tabela 5 - Produção de laranjas em mil (t), em 2018, por região do Brasil.

\begin{tabular}{ll}
\hline Sudeste & 14000 \\
\hline Nordeste & 1650 \\
\hline Sul & 1200 \\
\hline Norte & 360 \\
\hline Centro Oeste & 178
\end{tabular}

Fonte - IBGE, 2017.

Para Ströher et al. (2012), o bagaço de laranja in natura é um subproduto, que após a extração do suco é abundante. Um dos principais problemas enfrentados pelas indústrias processadoras de suco de laranja é o grande volume de resíduos sólidos e líquidos, produzidos diariamente.

Os sólidos, constituídos pelas cascas, sementes e polpas (figura 19), são na grande maioria dos casos utilizados como componente de ração animal, húmus, farelo de polpa cítrica, cama de frangos, adsorvente e silagem. Dentre os despejos líquidos, tem-se a "água amarela" e o óleo, a partir do qual pode-se produzir etanol celulósico, óleo essencial, entre outros produtos.

Essas indústrias possuem diferentes aplicações no mercado interno e externo, as quais incluem fabricação de produtos químicos e solventes, aromas e fragrâncias, substâncias para aplicação em indústrias de tintas, cosméticos, complemento para ração animal, entre outros (STRÖHER et al., 2012). 
Figura 19 - Diferenciação dos elementos da laranja.

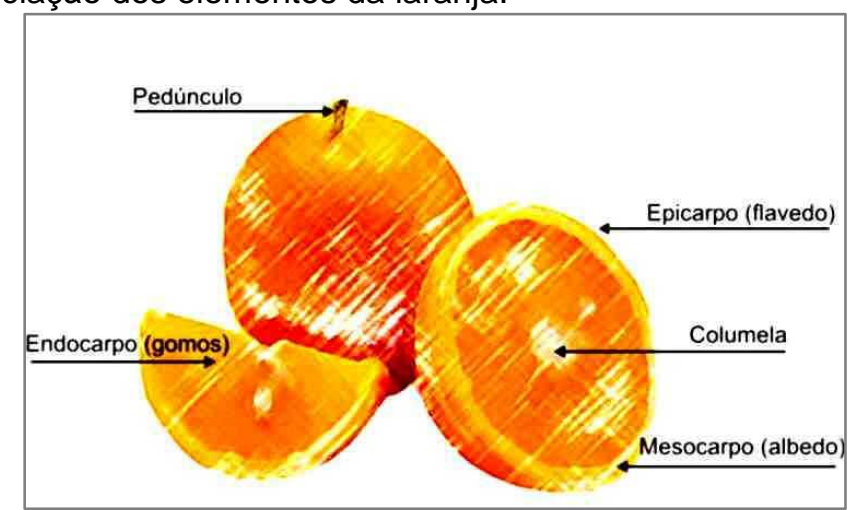

Fonte - GOOGLE IMAGENS, 2018.

Pesquisas científicas recentes vêm sendo realizadas para aprofundar os benefícios que esse resíduo pode gerar em sua reciclagem, principalmente como material biossorvente de metais tóxicos ao meio ambiente nos efluentes industriais e nesta pesquisa para contaminações oleosas (SANTOS, 2015; SOUZA et al., 2015; STRÖHER et al., 2012). 


\section{MATERIAIS E MÉTODOS}

\subsection{Matérias-primas}

Nessa pesquisa foram utilizadas fibras vegetais das cascas de banana, coco e laranja como biossorventes e o óleo diesel e a gasolina da marca Petrobras como contaminantes.

\subsection{Procedimento experimental}

Os biossorventes foram produzidos por processos mecânicos, físicos e químicos tais como: secagem, ativação química, moagem, classificação granulométrica, caracterização e ensaios de sorção. Com realização nas dependências dos Laboratórios do Centro de Ciência e Tecnologia de Materiais, Combustível Nuclear e Química e Meio Ambiente, desta instituição - IPEN.

\subsection{Obtenção e processamento dos biossorventes}

As fibras de coco foram adquiridas em pacotes de $200 \mathrm{~g}$, da marca Vitaplan, produtor Nutriplast Indústria e Comércio Ltda, sendo estocado uma quantidade de $2 \mathrm{~kg}$ para todos os ensaios. As bananas e laranjas foram compradas em feiras livres de São Paulo, sendo armazenada as suas cascas em estufa a $70^{\circ} \mathrm{C}$, até estarem completamente desidratadas (figura 20).

Figura 20 - (A) Cascas das laranjas secas; (B) Biossorventes da laranja processados.
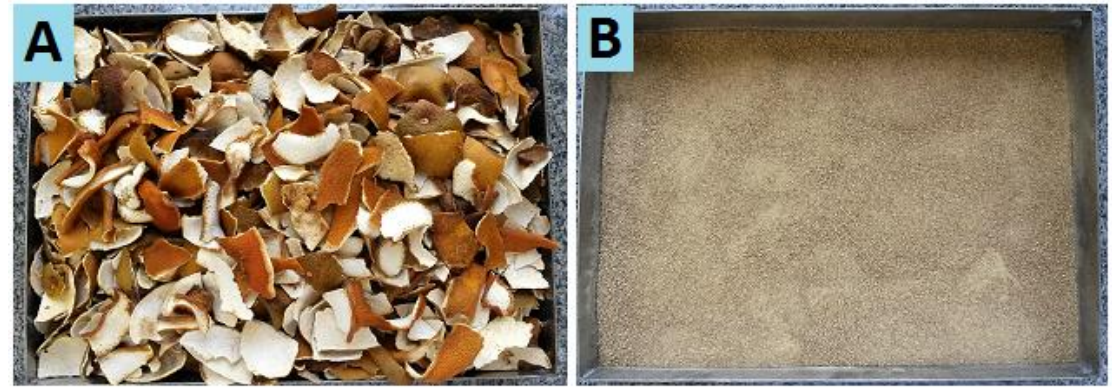

Fonte - autora da dissertação. 
A ativação dos biossorventes foi realizada com solução de hidróxido de sódio, concentração entre 3\% e 4\% em massa, sob agitação mecânica com o equipamento IKA RW 20 digital, por 2 a 3 horas (figura 21). Estes foram neutralizados em solução de ácido acético de $2 \%$ a $3 \%$ em volume, sob agitação por 1 hora e secos em estufa a $70^{\circ} \mathrm{C}$ por aproximadamente 72 horas.

Figura 21 - Processo de ativação e modificação química das cascas das bananas.

Fonte - autora da dissertação.

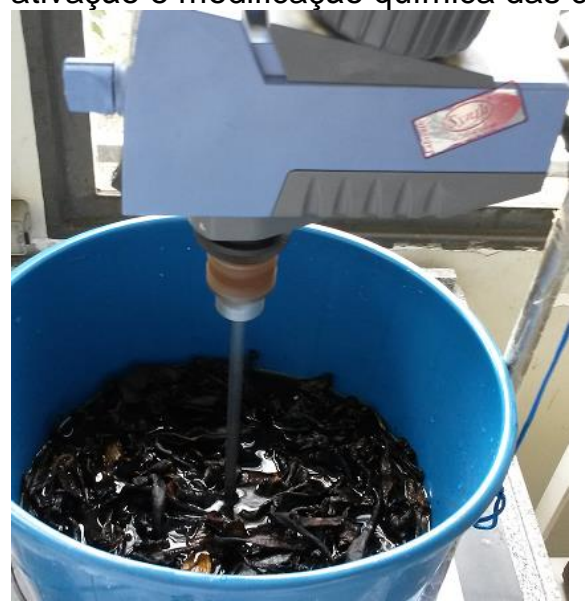

Os biossorventes, quando secos, foram triturados com moinho de facas até atingirem a granulometria adequada e caracterizados (figura 22). Este método foi adaptado pela autora da pesquisa.

Figura 22 - Fibras de coco processadas.

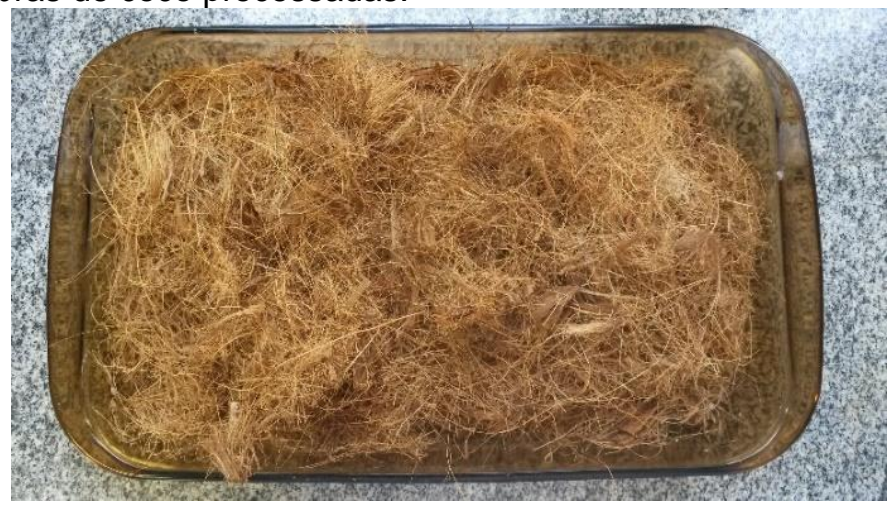

Fonte - autora da dissertação. 


\subsection{Caracterização}

Os biossorventes foram caracterizados pelas técnicas: picnometria, termogravimetria, análise elementar, microscopia eletrônica de varredura, teor de umidade, retenção de água pela biomassa seca, hidrofobicidade, flutuabilidade, teor de cinzas, fluorescência de raios $X$ e classificação granulométrica.

Algumas técnicas foram adaptadas da literatura, seguindo metodologias aplicadas por outros autores, com pesquisas semelhantes a esta (BORGES, 2015; OLIVEIRA, 2010; ANNUNCIADO, 2005; RIBEIRO, 2000). Os equipamentos utilizados e os métodos empregados nas caracterizações são apresentados a seguir.

1. Picnometria a gás hélio para determinação da densidade dos biossorventes, utilizando o equipamento Micromeritcs Instrument Corporation, modelo Accupyc 1330, nos parâmetros: número de purgas: 30, pressão de purga: 19,5 psi g, número de repetições: 30, pressão de preenchimento: 19,5 psi g, taxa de equilíbrio: 0,005 psi $\mathrm{g} / \mathrm{min}$, corrida de precisão: utilizada, porcentagem de variação: $0,05 \%$, temperatura da análise: $23{ }^{\circ} \mathrm{C}$;

2. Termogravimetria para determinação da temperatura de termo oxidação das fibras, utilizando o equipamento Shimadzu, modelo TGA $51 \mathrm{H}$, controle de sistema TA 60WS, com cerca de $2 \mathrm{mg}$ de amostra em cadinhos de alumina, ar como gás de arraste, vazão de $100 \mathrm{~mL} \cdot \mathrm{min}^{-1}$ e aquecimento de $20^{\circ} \mathrm{C}$ até 800 ${ }^{\circ} \mathrm{C}$ nas razões de $10{ }^{\circ} \mathrm{C} \cdot \mathrm{min}^{-1}$.

3. Análise elementar para determinação da porcentagem de Carbono, Hidrogênio, Nitrogênio e Enxofre das fibras, utilizando a técnica de oxidação e determinação por sorção na região do infravermelho e condutividade térmica, com os equipamentos analisador de $\mathrm{H}, \mathrm{O}$ e $\mathrm{N}$ modelo TCHEN 600, marca LECO e analisador de C e S, Modelo CS-400, marca LECO. 
4. Microscopia eletrônica de varredura para verificação da morfologia das fibras, utilizando o equipamento Tabletop Microscope, modelo TM 3000 da marca Hitachi.

5. Teor de umidade para determinação da porcentagem de umidade das fibras. Em uma balança analítica com o auxílio de um pesa filtro previamente tarado foi pesado aproximadamente $5 \mathrm{~g}$ da amostra $\left(\mathrm{m}_{1}\right)$. Após 4 horas em estufa à temperatura de $100{ }^{\circ} \mathrm{C}$, o pesa filtro foi levado ao dessecador até atingir temperatura ambiente, pesando-o novamente $\left(\mathrm{m}_{2}\right)$. $\mathrm{O}$ teste foi realizado em duplicata e 0 teor de umidade foi determinado através da equação 10 (OLIVEIRA, 2010).

$$
\operatorname{Umidade}(\%)=\frac{\left(m_{1}-m_{2}\right)}{m_{1}} \times 100
$$

Sendo:

- $\mathrm{m}_{1}=$ massa da amostra úmida $(\mathrm{g})$;

- $\mathrm{m}_{2}=$ massa da amostra seca $(\mathrm{g})$.

6. Retenção de água pela biomassa seca para determinação da quantidade em massa de água que os biossorventes retém durante um determinado período. Foi pesado $1 \mathrm{~g}$ da amostra $\left(\mathrm{m}_{1}\right)$, colocado em béquer de $50 \mathrm{~mL}$ contendo água destilada, misturado e deixado em contato por 5, 15, 30, 45 e 60 minutos. Após o tempo determinado, as amostras foram escoadas e pesadas $\left(m_{2}\right)$. $O$ ensaio foi realizado em duplicata e calculado através da equação 11 (OLIVEIRA, 2010).

$$
\text { Ret.de água }(g)=\frac{\left(m_{2}-m_{1}\right)}{m_{1}}
$$

Sendo:

- $\mathrm{m}_{1}=$ massa de amostra seca $(\mathrm{g})$;

- $\mathrm{m}_{2}=$ massa final da amostra úmida $(\mathrm{g})$. 
7. Hidrofobicidade para determinação da afinidade dos biossorventes por meios orgânicos, o método baseia-se na distribuição de um sólido em dois líquidos imiscíveis. Foi pesado $1 \mathrm{~g}$ de amostra $\left(m_{1}\right)$ em um béquer, em seguida adicionado $20 \mathrm{ml}$ de água destilada sob agitação com bastão de vidro. Posteriormente foi adicionado $20 \mathrm{~mL}$ de Hexano agitando-se por 3 minutos, seguido de repouso por 5 minutos. O material transferido para a fase orgânica foi retirado com um coletor, seco e pesado $\left(m_{2}\right)$. A hidrofobicidade foi realizada em duplicata e calculada pela equação 12 (OLIVEIRA, 2010).

$$
\text { Hidrofobicidade }(\%)=\frac{m_{2}}{m_{1}} \times 100
$$

Sendo:

- $\mathrm{m}_{1}=$ massa de amostra inicial $(\mathrm{g})$;

- $\mathrm{m}_{2}=$ material transferido para a fase orgânica (g).

8. Flutuabilidade para determinação da porcentagem de massa flutuante de fibras. Os testes foram aplicados em sistema estático e sistema dinâmico. Para o sistema estático $5 \mathrm{~g}$ de amostra foi imersa em um béquer de $600 \mathrm{~mL}$ durante 15 minutos e a porção flutuante, recolhida e calculada em relação à porção total. Para o sistema dinâmico $5 \mathrm{~g}$ da amostra foi adicionada em um béquer de 600 $\mathrm{mL}$ de água sob agitação (100 rpm) em agitador mecânico marca IKA RW 20 digital, durante 10 minutos, a porção flutuante foi recolhida e calculada como no sistema estático. A flutuabilidade foi determinada seguindo a equação 13 (OLIVEIRA, 2010).

$$
\text { Flutuabilidade }(\%)=\frac{m_{2}}{m_{1}} \times 100
$$

Sendo:

- $\mathrm{m}_{1}=$ massa inicial $(\mathrm{g})$;

- $\mathrm{m}_{2}=$ massa flutuante $(\mathrm{g})$. 
9. Teor de cinzas para determinação da porcentagem de elementos inorgânicos nas fibras. Um cadinho de porcelana foi colocado na mufla sob temperatura de $500 \stackrel{\circ}{\mathrm{C}}$ por 60 minutos. O cadinho foi retirado e, após esfriar em dessecador com sílica, foi pesado $\left(m_{1}\right)$ em balança analítica. Em seguida, foi adicionado 5 g de biomassa no cadinho de porcelana ficando em estufa por 24 horas à temperatura de $100 \stackrel{\circ}{\circ}$, retirando-o ficou esfriando em dessecador com sílica, pesando-o $\left(m_{2}\right)$. O cadinho foi levado para a mufla sob temperatura de $500 \stackrel{\circ}{\circ}$ a $600{ }^{\circ} \mathrm{C}$ durante 4 a 6 horas e retirado, deixando-o esfriar em dessecador até temperatura ambiente, pesando-o $\left(m_{3}\right)$. $O$ teste foi realizado em duplicata e o teor de cinzas determinado pela equação 14 (OLIVEIRA, 2010).

$$
\operatorname{Cinzas}(\%)=\frac{\left[\left(m_{3}-m_{1}\right) \times 100\right]}{\left(m_{2}-m_{1}\right)}
$$

Sendo:

- $\mathrm{m}_{1}=$ massa cadinho $(\mathrm{g})$;

- $\mathrm{m}_{2}=$ massa do cadinho + biomassa seca $(\mathrm{g})$;

- $\mathrm{m}_{3}=$ massa do cadinho + massa de cinzas $(\mathrm{g})$.

10. Fluorescência de raios $X$ por energia dispersiva (EDX) para determinação dos elementos inorgânicos que compõe as cinzas dos biossorventes, utilizando o equipamento Shimadzu, modelo EDX-720 em atmosfera a vácuo e collimator de $10 \mathrm{~mm}$. As cinzas para este ensaio foram produzidas utilizando mufla, em temperatura que variou entre $500{ }^{\circ} \mathrm{C}$ a $600 \stackrel{\circ}{ } \mathrm{C}$, durante 4 a 6 horas.

11. Classificação Granulométrica para determinação do tamanho dos grãos das fibras. Foi pesado $50 \mathrm{~g}$ de cada amostra e adicionado em agitador com peneiras de abertura 0,84 mm/20mesh, 0,50 mm/32mesh, 0,25 mm/60mesh, durante 5 minutos. A granulometria foi determinada seguindo a equação 15. 


$$
\text { Granulometria }(\%)=\frac{m_{2}}{m_{1}} \times 100
$$

Sendo:

- $\mathrm{m}_{1}=$ massa inicial da amostra $(\mathrm{g})$;

- $\mathrm{m}_{2}=$ massa correspondente a granulometria $(\mathrm{g})$ de cada peneira utilizada .

\subsubsection{Ensaios de sorção dos contaminantes}

Nestes estudos foram abordadas condições em sistema seco, cujos contaminantes estão em contato direto com os biossorventes, em ausência de água; e sistema aquoso, simulando derramamento em um corpo hídrico, onde o óleo, mesmo em contato com a água, está separado da mesma por uma interface nítida, sendo neste caso, com sistema estático e dinâmico.

Os biossorventes foram testados primeiramente de uma forma generalizada, sem definição granulométrica, e em seguida separadamente nas granulometrias citadas na metodologia. Os equipamentos utilizados e os métodos empregados são apresentados a seguir.

1. Sistema seco para determinação da sorção dos óleos contaminantes pelos biossorventes. Estes foram submetidos a ensaios de sorção de óleo diesel e gasolina nos tempos de 5, 15, 30, 45 e 60 minutos. Uma amostra de $1 \mathrm{~g}$ dos materiais $\left(m_{1}\right)$ foi adicionada em um béquer de $50 \mathrm{~mL}$ e submersa nos óleos. Após decorrido o tempo estipulado, os biossorventes foram escoados e pesados em balança analítica $\left(\mathrm{m}_{2}\right)$. Os ensaios foram realizados em temperatura ambiente, em duplicata e calculados conforme a equação 16.

$$
\text { Massa de óleo sorvido }(g)=\frac{\left(m_{2}-m_{1}\right)}{m_{1}}
$$

Sendo:

- $\mathrm{m}_{1}=$ massa inicial da amostra $(\mathrm{g})$;

- $\mathrm{m}_{2}=$ massa final da amostra com sorção do contaminante $(\mathrm{g})$. 
2. Sistema aquoso dinâmico e estático para determinação da sorção dos óleos pelos biossorventes, simulando derramamento em corpos hídricos. Estes foram submetidos a ensaios de sorção de óleo diesel e gasolina nos tempos de 10 , 20, 30, 45 e 60 segundos. A diferença de tempo entre o sistema seco, quantificado em minutos e aquoso em segundos, se deu devido a flutuabilidade e grau de sorção dos biossorventes. Estes, em contato com o óleo e a água, muito rapidamente se encharcavam e afundavam, ocorrendo o depósito no fundo do béquer. Assim, os biossorventes foram removidos em alguns segundos, antes de submergirem. Uma amostra de $4 \mathrm{~g}$ dos materiais $\left(m_{1}\right)$ foi adicionada a um béquer, contendo uma peneira com abertura de $0,18 \mathrm{~mm}$ para captação dos biossorventes, $300 \mathrm{~g}$ de água destilada e $10 \mathrm{~g}$ de óleo formando uma interface nítida. No sistema dinâmico, os biossorventes foram adicionados na solução, sob agitação magnética de 100 rpm, com o equipamento IKA RH basic 2, já no sistema estático os biossorventes foram adicionados na solução sem agitação. Após decorrido o tempo estipulado os materiais foram escoados por 30 segundos e pesados em balança analítica $\left(\mathrm{m}_{2}\right)$. A massa de água antes $\left(m_{3}\right)$ e depois do experimento $\left(m_{4}\right)$, também foi calculada. Para os testes em gasolina, foi descontada uma massa de $27 \%$ na água, correspondente a quantidade de etanol presente no combustível, que se dilui em contato com a solução aumentando o seu volume. Os ensaios foram realizados em temperatura ambiente, em duplicata e calculados conforme a equação 17:

$$
\text { Massa de óleo sorvido }(g)=\frac{\left(m_{2}-m_{1}\right)-\left(m_{3}-m_{4}\right)}{m_{1}}
$$

Sendo:

- $\mathrm{m}_{1}=$ massa inicial da amostra $(\mathrm{g})$;

- $\mathrm{m}_{2}=$ massa final da amostra com sorção do contaminante $(\mathrm{g})$;

- $\mathrm{m}_{3}=$ massa inicial de água $(\mathrm{g})$;

- $\mathrm{m}_{4}=$ massa final de água após a sorção (g). 
3. Isotermas de sorção em emulsões óleo/água, para determinação da relação da quantidade de poluente sorvido e a quantidade presente na solução. Para realização de um estudo de isotermas adiciona-se uma massa fixa do material sorvente em frascos com um volume fixo de solução contendo o sorvato. Neste experimento, a concentração do soluto é que varia. Assim, em cada frasco é adicionada uma concentração diferente de sorvato. A agitação, o tempo de contato entre o sorvato e sorvente e a temperatura devem ser mantidas constantes. Após o tempo de contato, faz-se a determinação da concentração do sorvato de cada frasco. A partir dos resultados, plota-se um gráfico relacionando a concentração do sorvato na fase líquida e na fase sólida (NASCIMENTO et al., 2014).

Assim, amostras de $2 \mathrm{~g}$ de material (M) foram adicionadas em $300 \mathrm{~mL}$ de emulsão óleo/água de concentrações distintas, que variaram de $10.000 \mathrm{mg} \mathrm{L}^{-1}$ a $70.000 \mathrm{mg} \mathrm{L}^{-1}\left(\mathrm{C}_{\mathrm{i}}\right)$ de óleo diesel, sob agitação com rotação de 300rpm, durante 1 minuto a $25{ }^{\circ} \mathrm{C}$ de temperatura. Após este intervalo de tempo, a agitação do sistema foi interrompida e procedeu-se a separação dos biossorventes em peneira metálica. As emulsões, após o tratamento, foram adicionadas em balão de separação, deixadas em repouso por 1 minuto e quantificada a concentração final do contaminante $\left(\mathrm{C}_{e}\right)$, os ensaios foram realizados em triplicata e calculados conforme as equações de equilíbrio (1, 3 e 9) citadas na revisão de literatura. 


\section{RESULTADOS E DISCUSSÕES}

\subsection{Caracterização dos materiais biossorventes}

A determinação das densidades dos biossorventes são demonstradas na tabela 6 , as fibras de coco e de banana, obtiveram resultados semelhantes, sendo a banana menos densa. A laranja apresentou resultado sensivelmente superior as outras duas fibras, porém também dentro dos parâmetros para fibras vegetais. Estes biossorventes estudados são particularmente mais densos do que a água, o que influencia no processo de sorção que, a priori, é beneficiado com a flutuosidade da fibra (ANNUNCIADO, 2005).

Tabela 6 - Densidade dos biossorventes.

\begin{tabular}{ll}
\hline Banana & $1,430( \pm 0,001) \mathrm{g} / \mathrm{cm}^{3}$ \\
\hline Coco & $1,470( \pm 0,004) \mathrm{g} / \mathrm{cm}^{3}$ \\
\hline Laranja & $1,540( \pm 0,001) \mathrm{g} / \mathrm{cm}^{3}$ \\
\hline \multicolumn{1}{c}{ Fonte - autora da dissertação. } &
\end{tabular}

Os resultados da análise elementar do conteúdo de hidrogênio, nitrogênio, oxigênio, carbono e enxofre para as amostras dos biossorventes (tabela 7), demonstram que todos possuem quantidade relativamente semelhante de carbono, com maior concentração para as fibras da banana, assim como o hidrogênio. O coco destaca-se em concentração superior de nitrogênio e enxofre.

Cortez et al., (2009), encontrou os seguintes valores para a análise elementar da fibra de coco: C $(42,11 \%), \mathrm{H}(5,35 \%), \mathrm{N}(0,95 \%)$ e S $(0,13 \%)$. O teor de carbono observado nesta pesquisa, se mostrou sensivelmente acima do valor encontrado por Cortez, assim como o teor de nitrogênio e enxofre, pois estes valores podem variar em função de algumas características, como a variedade e grau de maturação (coco verde ou seco).

Nas pesquisas de Paniagua et al., (2015), foram encontrados para fibras da banana, as concentrações de: C (47,13\%), H (6,47\%), N (1,34\%) e S $(0,90 \%)$. Se comparado a esta pesquisa, os valores de carbono são semelhantes, porém os de 
hidrogênio, nitrogênio e enxofre se diferem, isso pode ocorrer devido a variação de produtos naturais ser bastante significativa, conforme tipo de solo, local de cultivo e variedade de frutos.

Tabela 7 - Análise elementar dos biossorventes (\% mássica).

\begin{tabular}{lccccc}
\hline & $\mathbf{H}(\%)$ & $\mathbf{N}(\%)$ & $\mathbf{O}(\%)$ & $\mathbf{C}(\%)$ & $\mathbf{S}(\%)$ \\
\hline Banana & $0,91( \pm 0,03)$ & $0,74( \pm 0,02)$ & $59,3( \pm 0,20)$ & $46,6( \pm 0,20)$ & $0,22( \pm 0,03)$ \\
\hline Coco & $0,74( \pm 0,02)$ & $1,32( \pm 0,03)$ & $54,5( \pm 0,30)$ & $45,6( \pm 0,30)$ & $0,42( \pm 0,02)$ \\
\hline Laranja & $0,62( \pm 0,02)$ & $0,88( \pm 0,02)$ & $48,4( \pm 0,20)$ & $43,2( \pm 0,10)$ & $0,32( \pm 0,01)$ \\
\hline
\end{tabular}

Fonte - autora da dissertação.

A tabela 8 apresenta os resultados de teor de umidade, hidrofobicidade, flutuabilidade e cinzas. O biossorvente que apresentou melhor hidrofobicidade foi o coco, nos ensaios verificou-se que suas fibras migraram da fase da água para a fase de hexano, portanto são hidrofóbicas. O coco obteve resultados igualmente satisfatórios para os ensaios de flutuabilidade, com quase $100 \%$ tanto no sistema estático quanto no dinâmico, Annuciado (2005), demostrou resultados semelhantes em sua pesquisa com as fibras de coco.

As fibras da banana, embora tenham apresentado baixa hidrofobicidade, demostraram boa flutuabilidade, principalmente no sistema dinâmico. Segundo Ribeiro (2000), esse fenômeno pode ocorrer devido à presença de ceras hidrorrepelentes na superfície das fibras, além de cavidades que aprisionam bolsas de ar. Estas ceras formam uma camada de proteção nas fibras que confere um caráter oleofílico e hidrofóbico nas superfícies (ANNUNCIADO, 2005). Esta repelência pela água permite que o óleo, o qual tem menor tensão superficial que a água, penetre na superfície seca do biossorvente (RIBEIRO et al., 2000).

A flutuabilidade diz respeito ao comportamento do biossorvente em condições estáticas e dinâmicas, ou seja, a verificação do comportamento do material parado e sob agitação, simulando o movimento de ondas em um meio líquido (RIBEIRO, 2000).

O teor de cinzas está relacionado com a quantidade de matéria inorgânica presente nos biossorventes. Conforme tabela 8 , as fibras de banana e laranja apresentaram elevada quantidade de cinzas, devido a contribuição importante de 
elementos como cálcio, potássio e sódio, a concentração desses minerais presentes no solo, se acumulam na planta como um todo. Ribeiro (2000), relaciona o teor de cinzas inversamente proporcional a hidrofobicidade dos biossorventes, segundo o autor quanto menor a quantidade de cinzas, maior sua hidrofobicidade (figura 23).

Tabela 8 - Teor de umidade, hidrofobicidade, flutuabilidade e cinzas (\% mássica). Umidade (\%) Hidrofobicidade

Flutuabilidade

Cinzas

(\%)

(\%)

(\%)

\begin{tabular}{lccccc}
\hline & & \multicolumn{3}{c}{ Estático } & Dinâmico \\
\hline Banana & 1,2 & 4,9 & 49,9 & 61,0 & 16,7 \\
\hline Coco & 2,2 & 36,6 & 99,4 & 99,9 & 1,6 \\
\hline Laranja & 2,0 & 7,5 & 25,3 & 33,9 & 11,5 \\
\hline
\end{tabular}

Fonte - autora da dissertação.

Figura 23 - Relação entre a porcentagem de hidrofobicidade $\mathrm{X}$ teor de cinzas dos biossorventes (\% mássica).

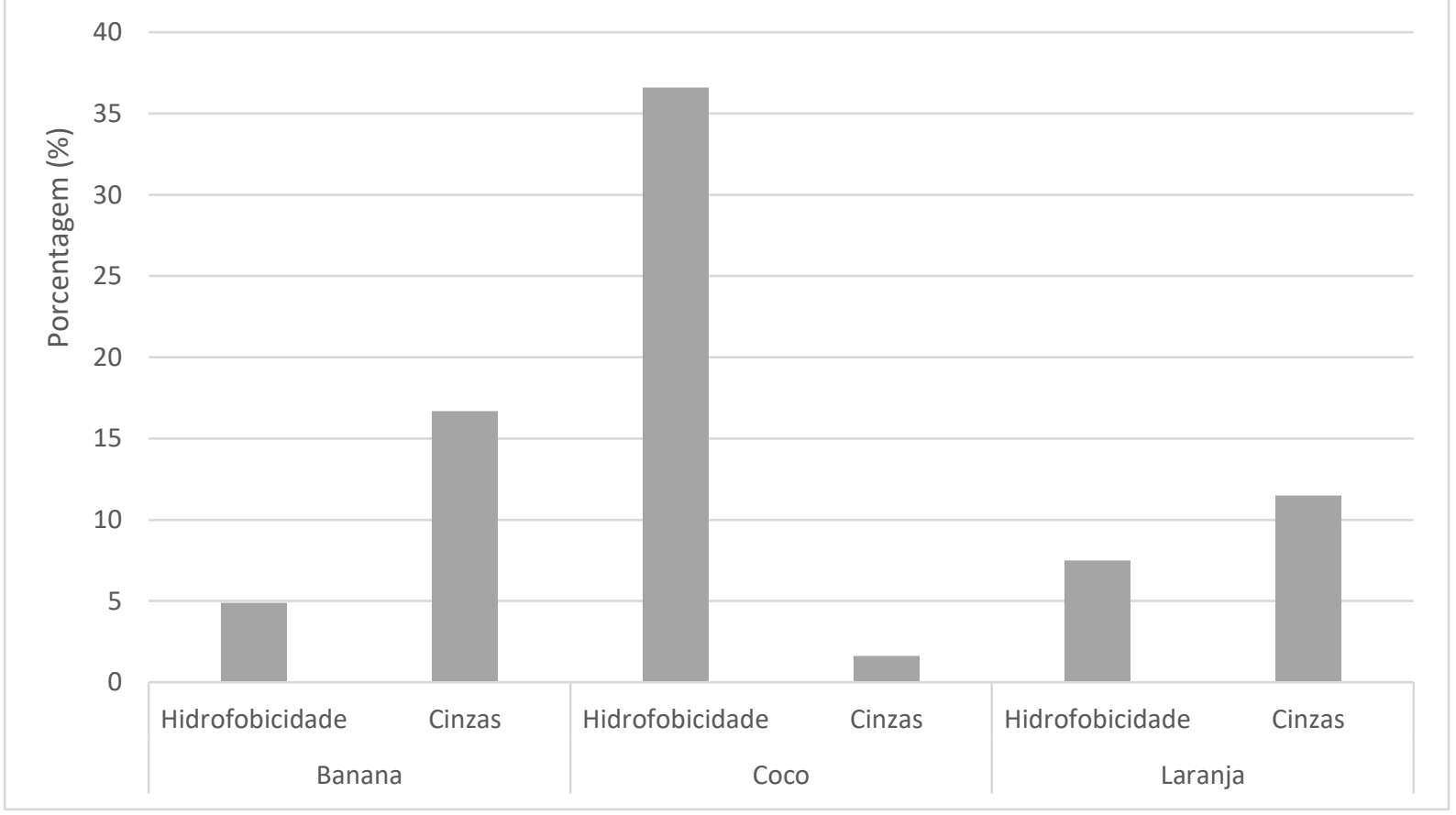

Fonte - autora da dissertação.

A análise quantitativa das cinzas dos biossorventes, foi determinada por Fluorescência de raios X, os resultados são apresentados na tabela 9 e na figura 24 . Os elementos encontrados em maior quantidade são o cálcio $(\mathrm{Ca})$, potássio $(\mathrm{K})$, sódio (Na) e o silício (Si), típicos de substâncias provindas do solo. Outros elementos como 
ferro $(\mathrm{Fe})$, magnésio $(\mathrm{Mg})$ e enxofre $(\mathrm{S})$, também estão presentes, porém em concentrações menores.

Tabela 9 - Análise quantitativa dos elementos presentes nos biossorventes (\% mássica).

\begin{tabular}{clll}
\hline Elementos & Coco (\%) & Banana (\%) & Laranja (\%) \\
\hline $\mathbf{B a}$ & 0,3510 & 0 & 0 \\
\hline $\mathbf{B r}$ & 0,1380 & 0 & 28,556 \\
\hline $\mathbf{C a}$ & 55,919 & 17,739 & 0,0750 \\
\hline $\mathbf{C u}$ & 0,1780 & 0,0700 & 0,1300 \\
\hline $\mathbf{F e}$ & 1,4420 & 0,2740 & 8,8150 \\
\hline $\mathbf{K}$ & 5,2160 & 43,437 & 0 \\
\hline $\mathbf{M g}$ & 7,5580 & 2,9310 & 0 \\
\hline $\mathbf{M n}$ & 0,1610 & 1,0340 & 60,522 \\
\hline $\mathbf{N a}$ & 0 & 27,672 & 1,1560 \\
\hline $\mathbf{P}$ & 0,9770 & 0,8470 & 0,0170 \\
\hline $\mathbf{R b}$ & 0 & 0 & 0,1990 \\
\hline $\mathbf{S}$ & 3,6820 & 0,1970 & 0 \\
\hline $\mathbf{S i}$ & 23,428 & 5,4200 & 0,3000 \\
\hline $\mathbf{S r}$ & 0,6590 & 0,2070 & 0,0750 \\
\hline $\mathbf{Z n}$ & 0,2800 & 0,1720 & 0,1570 \\
\hline $\mathbf{Z r}$ & 0 & 0 &
\end{tabular}

Fonte - autora da dissertação. 
Figura 24 - Análise quantitativa dos elementos presentes nos biossorventes (\% mássica).

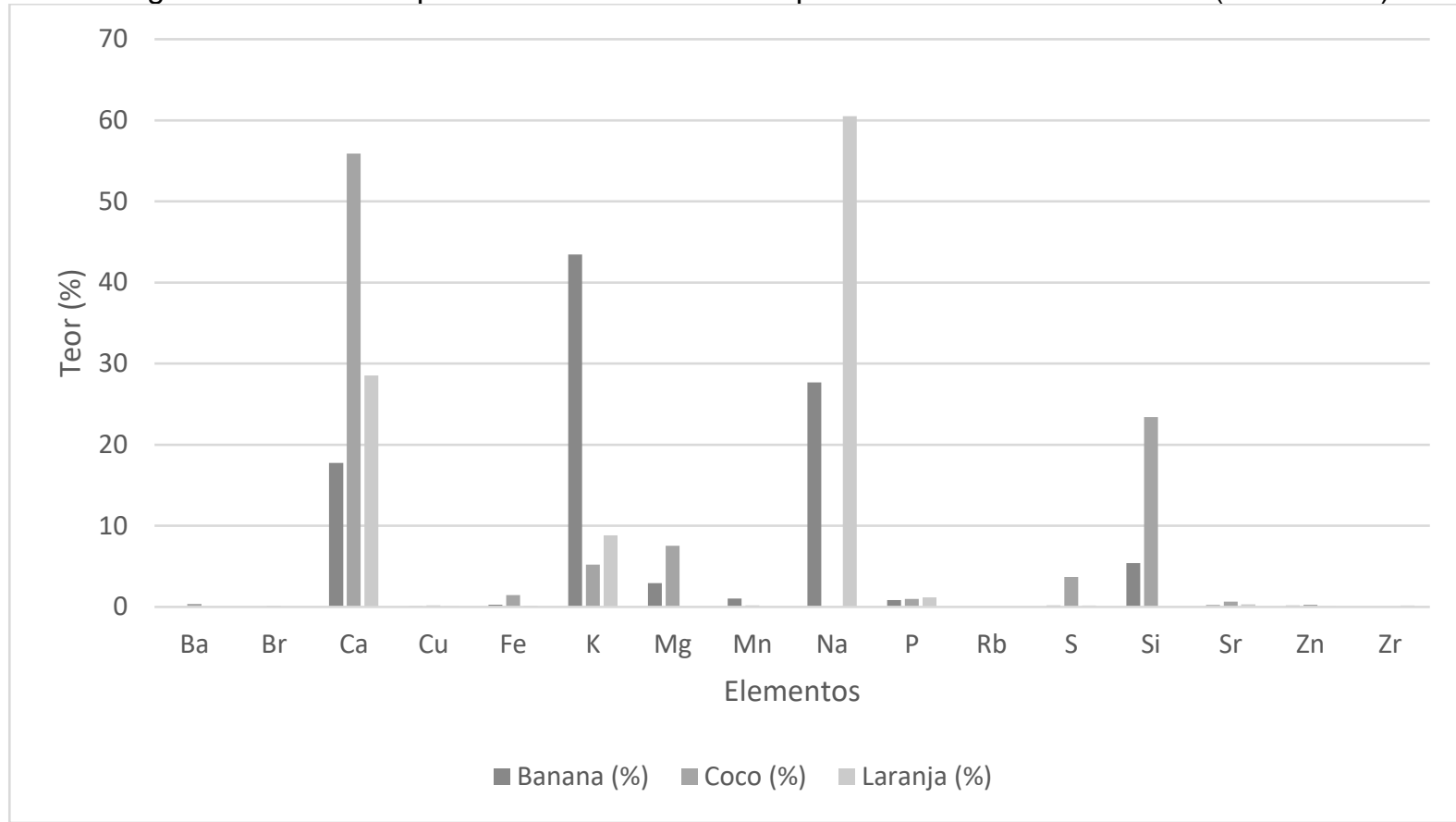

Fonte - autora da dissertação.

Os testes de retenção de água pela biomassa seca, dizem respeito à capacidade do biossorvente reter água após ser misturado sob ação mecânica, seguida de escoamento, ou seja, a retenção de água por meios forçados. A tabela 10 e a figura 25 , demonstram os resultados de capacidade de retenção de água dos biossorventes.

O coco e a banana obtiveram resultados semelhantes, absorveram cerca de 3,3 vezes a sua massa inicial em decorridos 45 minutos, a laranja obteve maior retenção de água, sendo cerca de 6,4 vezes a sua massa inicial, neste mesmo período.

Os resultados obtidos pelo método de retenção de água e pelo da flutuabilidade são diferentes, pois as questões envolvidas são distintas. Por retenção, o biossorvente foi misturado mecanicamente com a água, sendo forçado o escoamento para drenagem do excesso do líquido. Por flutuabilidade, os biossorventes foram dispostos sobre a superfície da água e o escoamento ocorreu por gravidade. 
Tabela 10 - Retenção de água pela biomassa seca (gágua/gbiossorvente).

\begin{tabular}{lccccc}
\hline Biossorventes $\mathbf{g} / \mathbf{g})$ & $\mathbf{5} \mathbf{~} \mathbf{~ i n}$ & $\mathbf{1 5} \mathbf{~} \mathbf{~ i n}$ & $\mathbf{3 0} \mathbf{~ m i n}$ & $\mathbf{4 5} \mathbf{~}$ in & $\mathbf{6 0} \mathbf{~ m i n}$ \\
\hline Banana & $2,62( \pm 0,11)$ & $2,96( \pm 0,14)$ & $3,04( \pm 0,06)$ & $3,28( \pm 0,14)$ & $3,14( \pm 0,05)$ \\
\hline Coco & $2,77( \pm 0,12)$ & $2,85( \pm 0,12)$ & $3,09( \pm 0,11)$ & $3,28( \pm 0,09)$ & $2,95( \pm 0,02)$ \\
\hline Laranja & $5,94( \pm 0,12)$ & $6,29( \pm 0,16)$ & $6,34( \pm 0,03)$ & $6,36( \pm 0,03)$ & $6,76( \pm 0,12)$
\end{tabular}

Fonte - autora da dissertação.

Figura 25 - Retenção de água pela biomassa seca (gágua/gbiossorvente).

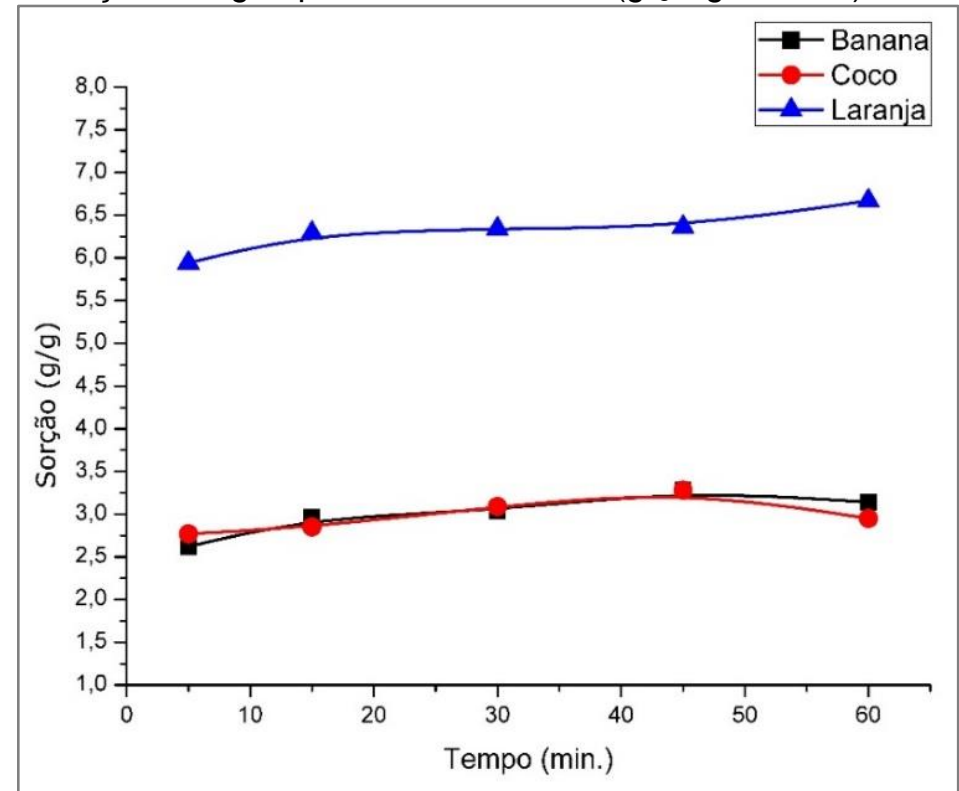

Fonte - autora da dissertação.

As fibras vegetais apresentaram degradação térmica em duas etapas principais. A primeira corresponde à despolimerização térmica da hemicelulose e a quebra de ligações glicosídicas da celulose. A segunda está relacionada com a decomposição da $\alpha$-celulose. A decomposição da lignina acontece numa ampla faixa de temperatura, entre 200 e $500^{\circ} \mathrm{C}$ (RAMBO et. al., 2015; PAULA, 2011).

As curvas de termogravimetria apresentadas na figura 26, mostram que os biossorventes possuem estabilidade térmica até aproximadamente $200^{\circ} \mathrm{C}$, quando ocorre o início da termo oxidação, correspondente ao princípio da decomposição de hemiceluloses, seguida da celulose. Vale ressaltar que a perda de massa inicial, se refere à perda de substâncias voláteis e, majoritariamente, umidade contida nas amostras. 
Em torno de $350^{\circ} \mathrm{C}$ observa-se o início de outro processo de decomposição, envolvendo ligações de lignina, prosseguindo com o aumento de temperatura até ocorrer a perda de massa quase total após a $500^{\circ} \mathrm{C}$.

Rambo et. al., (2015), demonstra em sua pesquisa as curvas termogravimétricas de diferentes biomassas lignocelulósicas, dentre elas a do coco. Sendo que todas apresentaram comportamento típico de degradação térmica para este material: liberação de umidade na faixa de 50 a $100^{\circ} \mathrm{C}$, decomposição de carboidratos (hemicelulose e celulose) no intervalo de 250 a $400^{\circ} \mathrm{C}$, acima de $400^{\circ} \mathrm{C}$ uma degradação contínua e lenta associada a lignina e ao final do processo, quando ocorre a formação de carvão e cinzas.

Figura 26 - Curvas de termogravimetria (A) coco, (B) banana e (C) laranja.

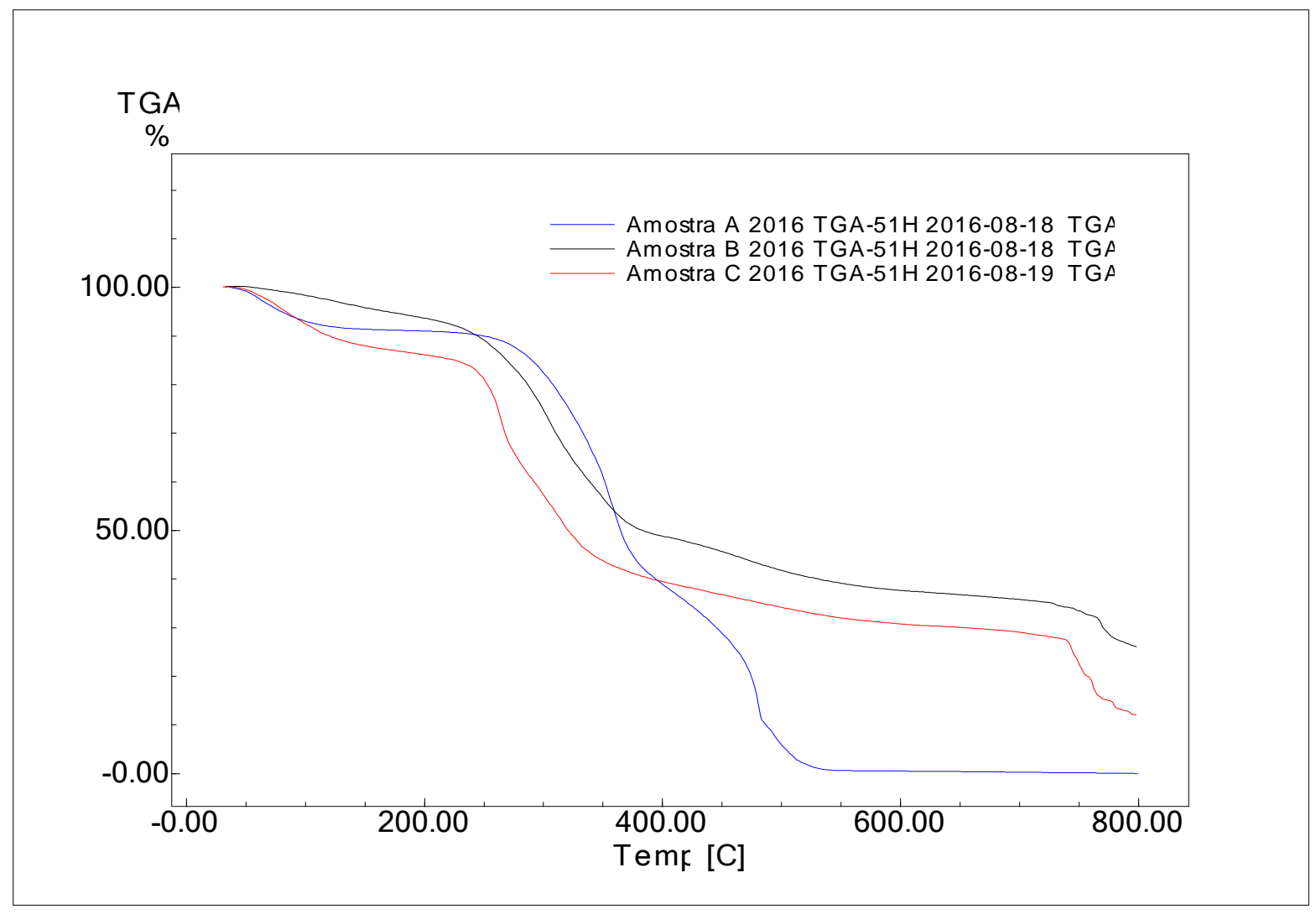

Fonte - autora da dissertação.

A classificação granulométrica das fibras de banana e laranja é apresentada na figura $27 \mathrm{~A}$, as do coco foram cortadas no comprimento entre $5 \mathrm{~cm}$ e $8 \mathrm{~cm}$, logo, não 
foram selecionadas nas peneiras. A distribuição varia entre 0,84 $\mathrm{mm} \mathrm{e}<0,25 \mathrm{~mm}$, sendo a porção mais homogênea entre $0,5 \mathrm{~mm}$ com aproximadamente $40 \%$ para a banana e 34\% para a laranja e 0,25 $\mathrm{mm}$ com 30\% para a banana e $~ 24 \%$ para a laranja.

O coco a princípio, não entraria neste ensaio granulométrico por manter o formato de fibras e não grãos. Posteriormente foi verificada a importância de também estabelecer este parâmetro no biossorvente. Assim, ele foi triturado em moinho de bolas e classificado em peneiras, mantendo o padrão da banana e da laranja, sendo executado os ensaios de sorção de contaminantes (figura 27 B).

Figura 27 - Classificação granulométrica das fibras de laranja e banana, realizada por peneiras. A - Gráfico

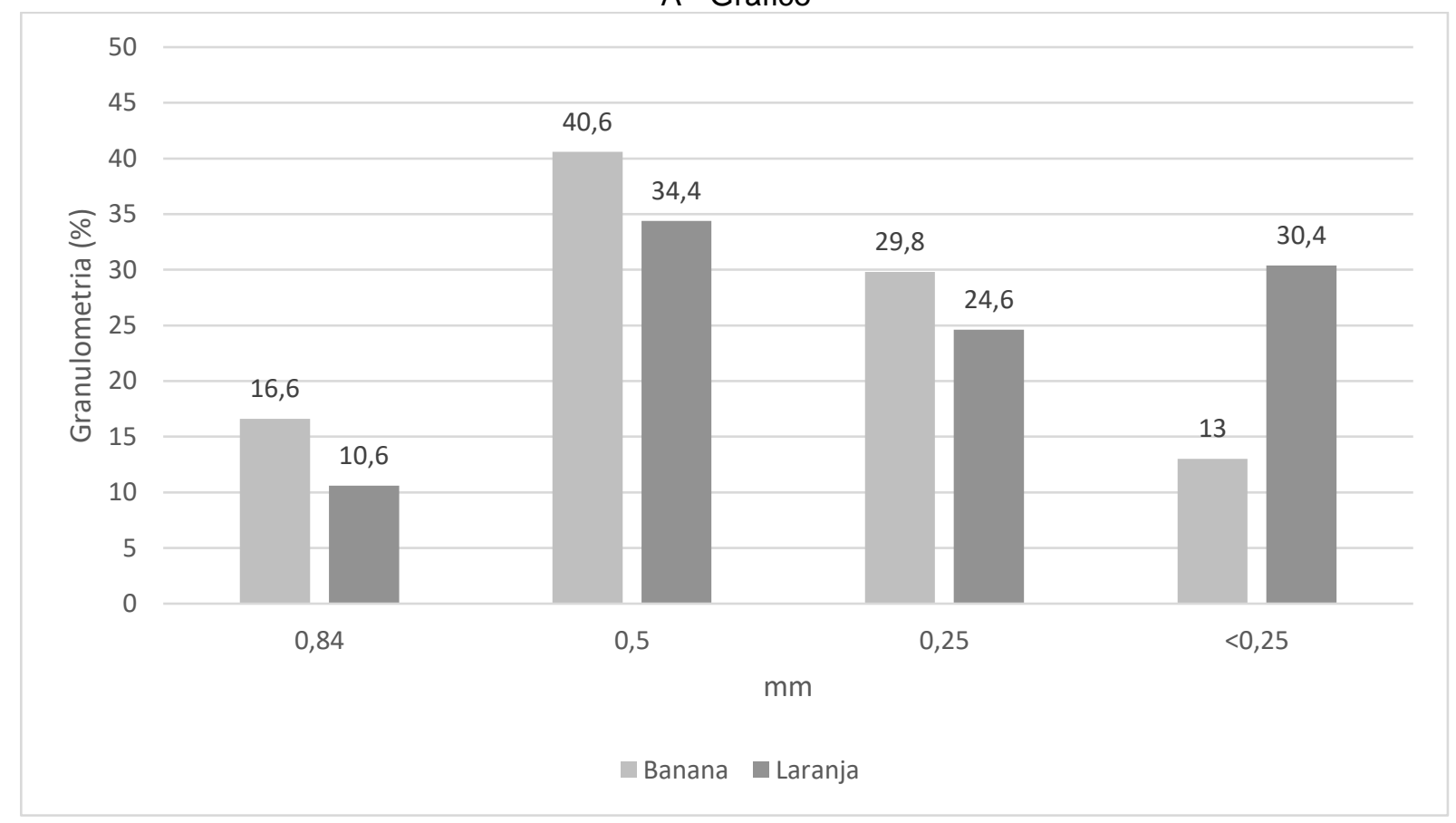




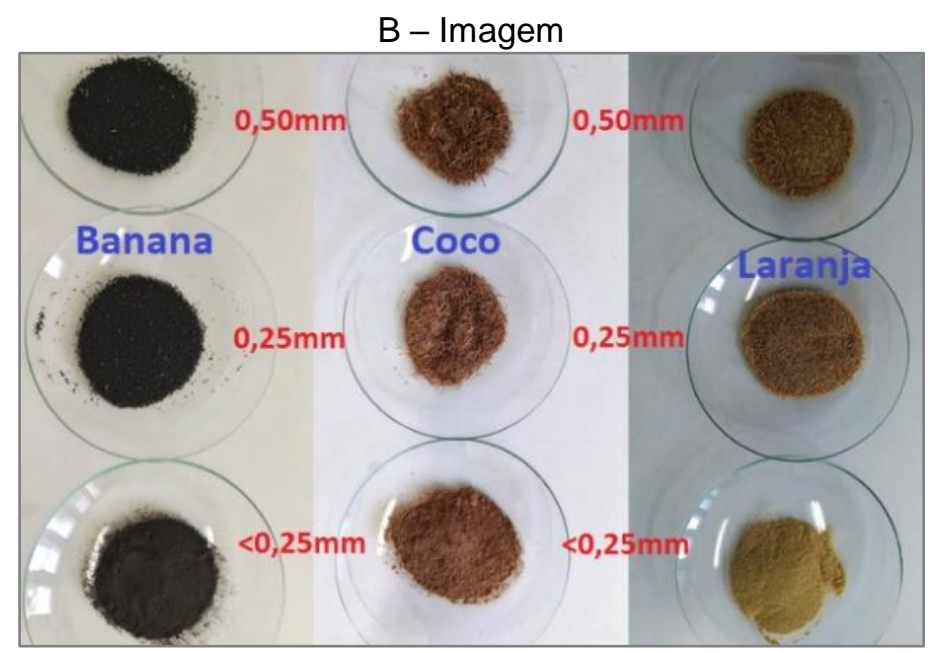

Fonte - autora da dissertação.

As imagens da Microscopia Eletrônica de Varredura obtidas nas figuras 28, 29 e 30 mostram a morfologia dos biossorventes antes e depois da modificação química. Através da topografia do material, é possível verificar a homogeneidade e a formação de poros dos biossorventes.

O tratamento alcalino de material lignocelulósico é um processo irreversível e leva a uma mudança na estrutura supramolecular e na sua morfologia, facilitando sua solubilização. Duas diferentes estruturas da cadeia de celulose (tipo I e tipo II) podem ser formadas (KROON-BATENBURG e KROON, 1997).

Este tratamento também remove componentes como lignina e hemicelulose. Assim, o aumento da capacidade de sorção em fibras lignocelulósicas submetidas a tratamento alcalino pode ser atribuída à formação de celulose do tipo II, que tem grupos hidroxilas mais disponíveis. (NASCIMENTO et al., 2014). 
Na figura 28 observa-se a superfície dos grãos das fibras da banana, as imagens de A a D mostram os biossorventes processados, após ativação química e trituração, os grãos têm formato arredondado e grande quantidade de poros. Com os aumentos de 250 (figura B) a 500 vezes (figura D), percebe-se claramente a porosidade do material. A imagem E demonstra a superfície externa da casca da banana e a $\mathrm{F}$ a interna, ambos naturais, sem qualquer tipo de processo químico.

Figura 28 - (A) Superfície natural interna da casca de banana; (B) superfície natural externa da casca de banana; (C) e (D) grãos dos biossorventes da banana tratados e processados.

A

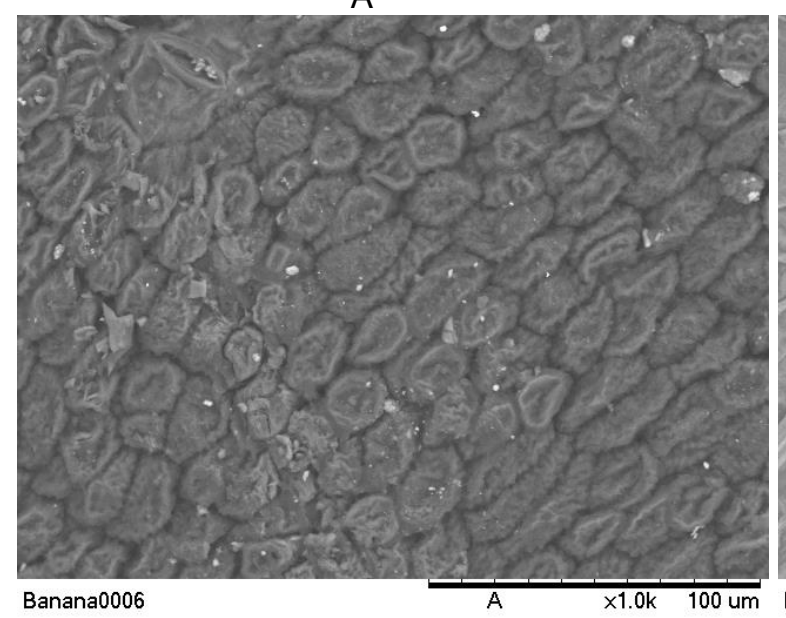

C

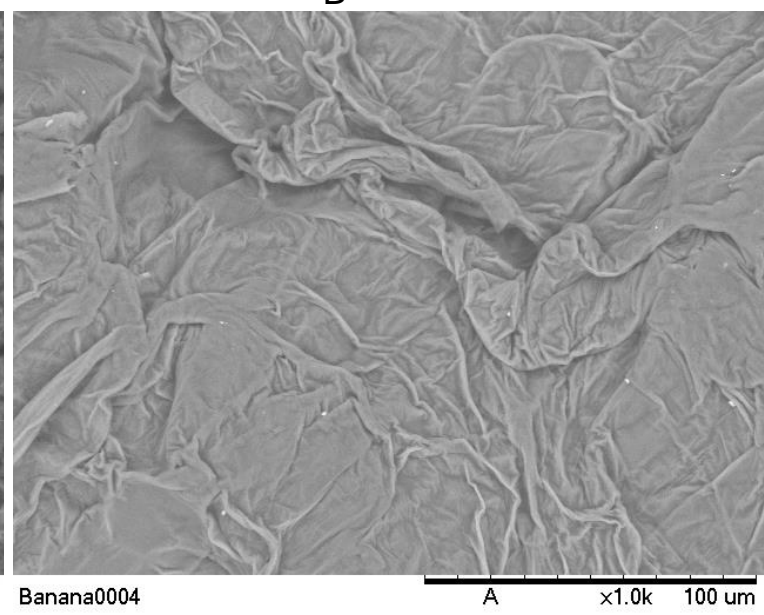

D
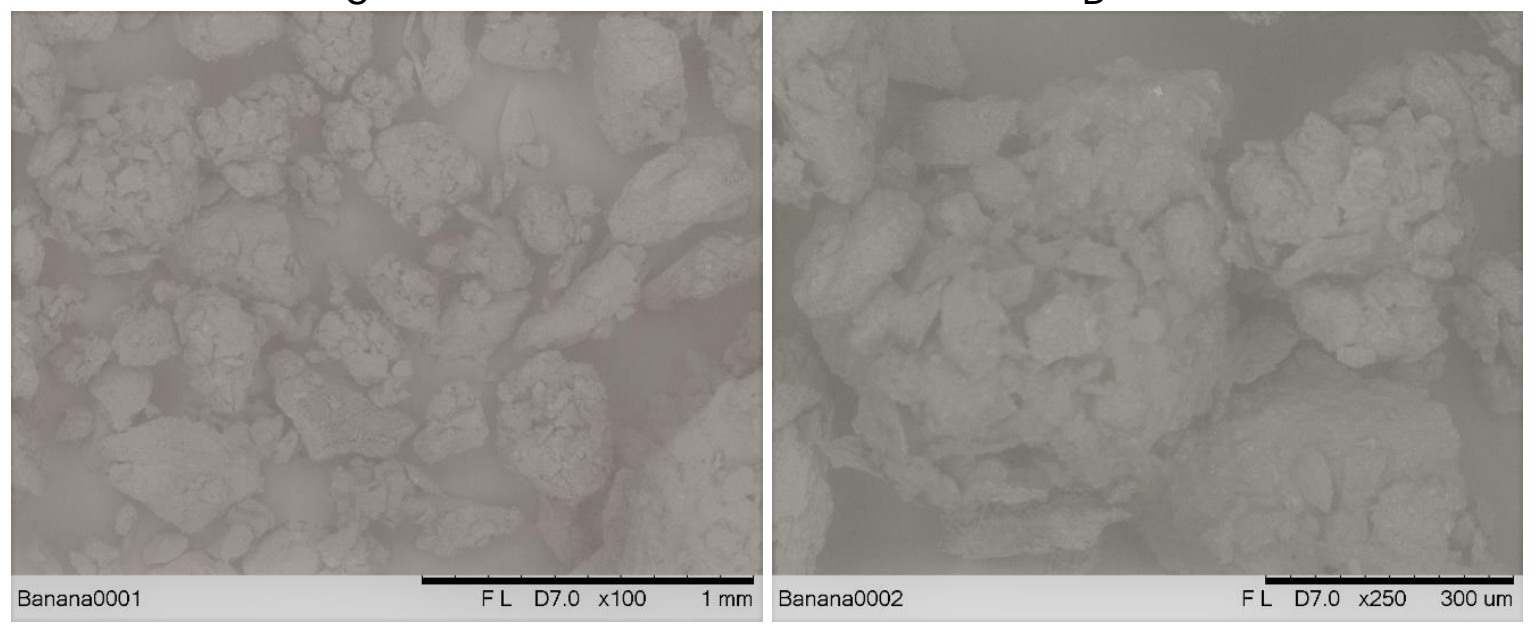

Fonte - autora da dissertação. 
Na figura 29 observa-se a superfície da fibra do coco, as ranhuras das imagens de $A$ a $D$ foram causadas pela modificação química, onde o tratamento removeu a primeira camada da fibra, causando rugosidade na superfície, comparando as imagens E e F que mostram a superfície natural da fibra, isso pode ser claramente visualizado. O aumento da rugosidade facilita o processo de sorção, por aumentar a quantidade de poros no material.

Figura 29 - (A) e (B) Superfície natural das fibras de coco; (C) e (D) superfície tratada das fibras de coco.

A
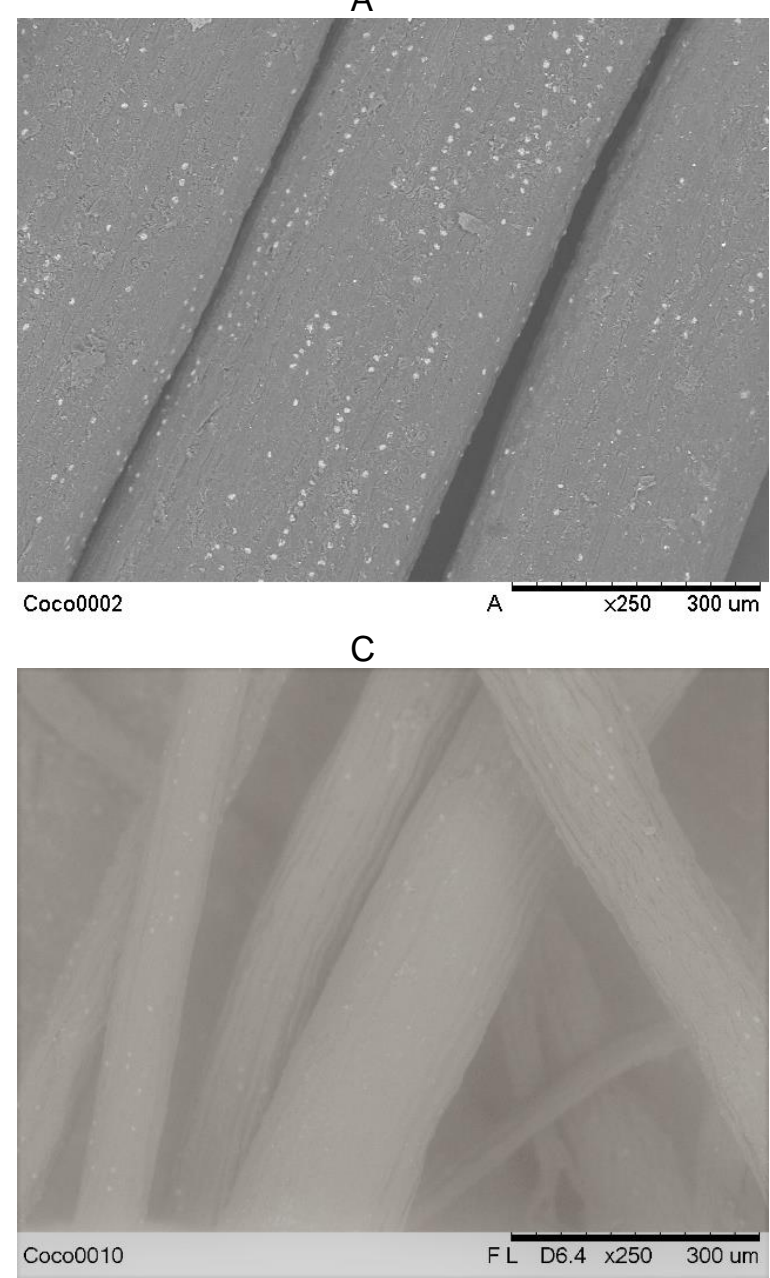

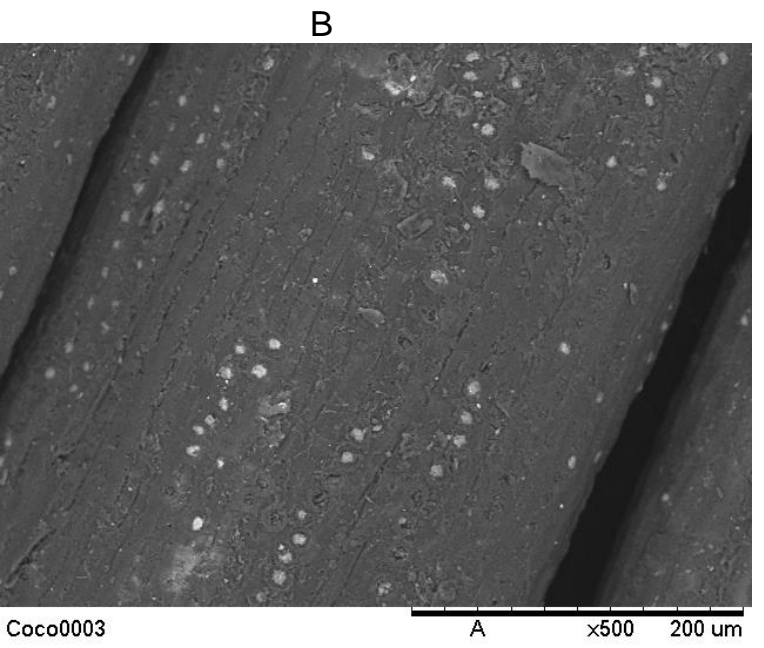

D

Fonte - autora da dissertação.

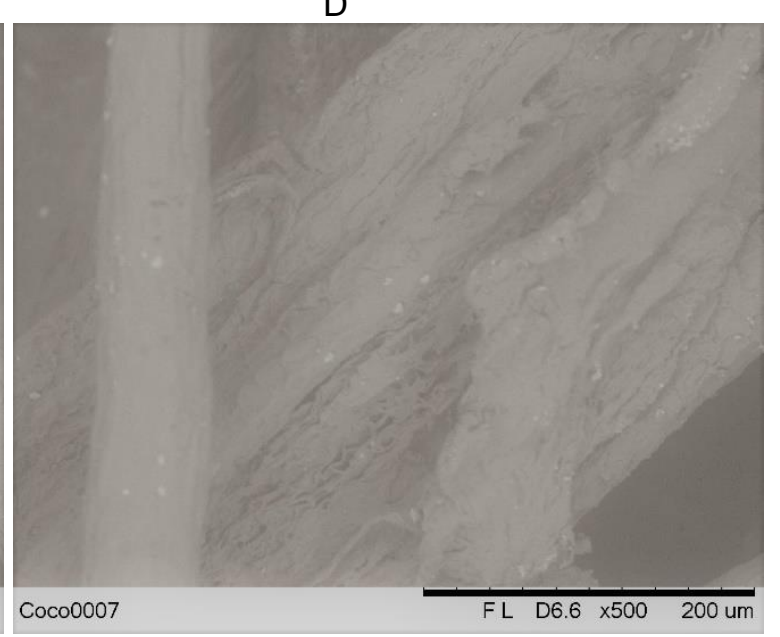


Na figura 30 observa-se a superfície dos grãos das fibras da laranja, sendo de A a D o material processado por modificação química e trituração, os grãos possuem formato menos arredondado do que a banana (figura 28), porém sua superfície é mais porosa. As figuras E e F demonstram as fibras naturais da laranja, sem tratamento químico, onde percebe-se claramente esta porosidade, sendo, dos três biossorventes o que é mais poroso.

Figura 30 - (A) Superfície natural da casca de laranja; (B) e (C) grãos dos biossorventes da laranja tratados e processados.

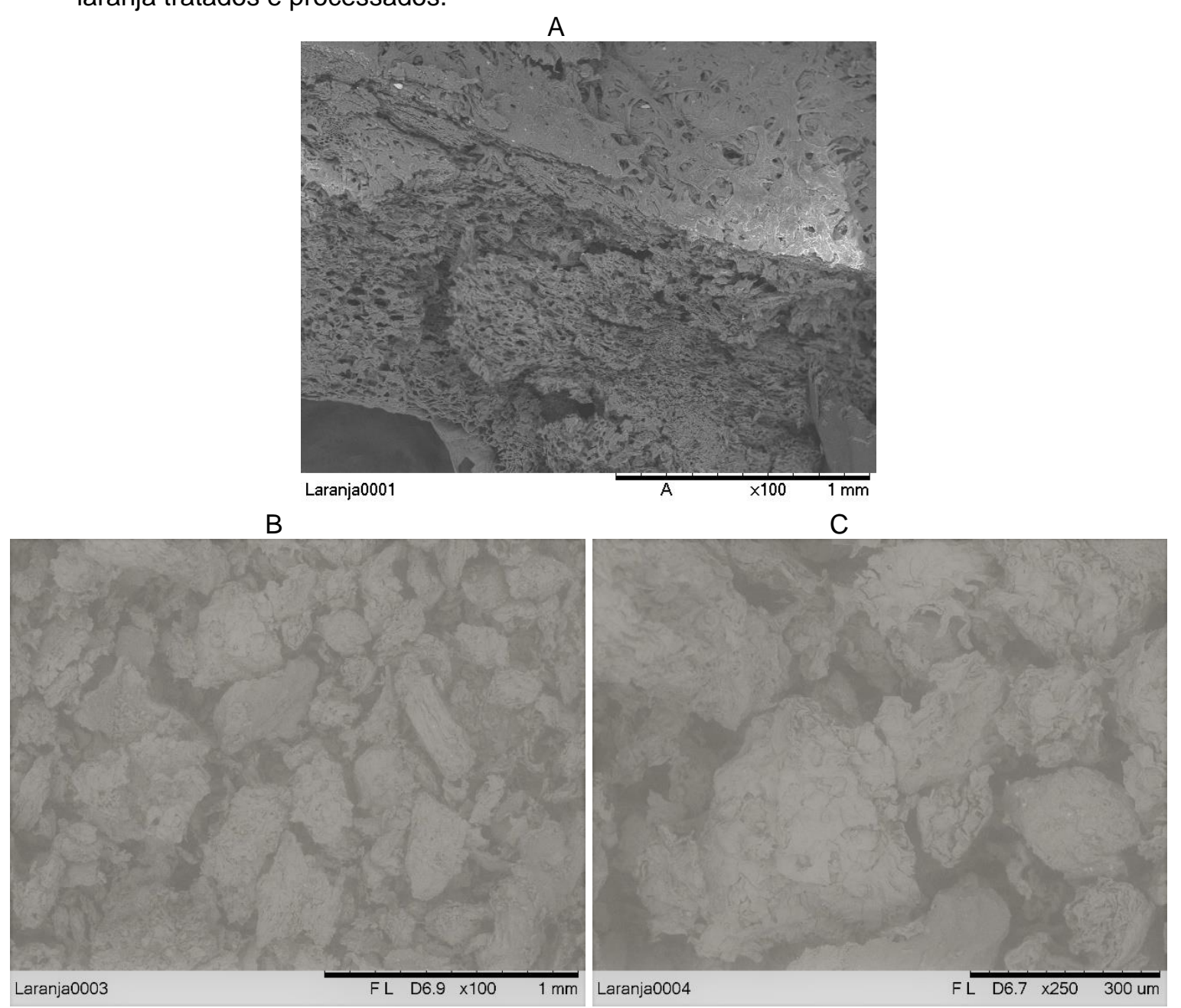

Fonte - autora da dissertação. 
Os teores de celulose, hemicelulose e lignina foram coletados da literatura e comparados entre os biossorventes estudados (tabela 11). A celulose compôs a maior porcentagem de concentração, com média de $61 \%$ para a banana, $47 \%$ para o coco, e 15,4\% para a laranja. Tanto ela, quanto a lignina possuem características oleofílicas, favorecendo a sorção de óleos frente à da água presente no meio (BORGES, 2015). A lignina foi encontrada em maior concentração no coco, com cerca de $31 \%$, para $11 \%$ da banana e $4 \%$ da laranja.

Já a hemicelulose confere estruturas hidrofílicas as fibras vegetais, e variaram entre 10 e $35 \%$ entres os biossorventes estudados, com maior concentração na banana e no coco. Para Borges (2015), as diferenças existentes entre os valores encontrados pelos diversos autores podem ser atribuídas ao tipo de fibra; ou até mesmo quando da mesma espécie, a área do vegetal analisado pode resultar diferenças. Além dos métodos para a determinação destes componentes. (KIM et al., 2015; SÁNCHEZ et al., 2014; DEEPA et al., 2011; BENELLI, 2010; OLIVEIRA, 2010; PEREIRA, 2010; KELLEY et al., 2004; ROJA E NEVES, 2002; HILL et al., 1998).

Tabela 11 - Teores de celulose, hemicelulose e lignina dos biossorventes (\% mássica).

\begin{tabular}{lccc}
\hline \multicolumn{1}{c}{ Biossorventes } & Celulose (\%) & Hemicelulose (\%) & Lignina (\%) \\
\hline Banana & $53,5^{\mathrm{A}} ; 64,0^{\mathrm{B}} ;$ & $15,9^{\mathrm{A}} ; 19,0^{\mathrm{B}} ;$ & $11,3^{\mathrm{A}} ; 5,0^{\mathrm{B}} ;$ \\
& $64,3^{\mathrm{C}}$ & $35,7^{\mathrm{C}}$ & $11,6^{\mathrm{C}}$ \\
\hline Coco & $47,6^{\mathrm{D}} ; 46,0^{\mathrm{E}} ; 47,0^{\mathrm{F}}$ & $27,4^{\mathrm{D}} ; 21,0^{\mathrm{E}} ; 15,0^{\mathrm{F}}$ & $31,5^{\mathrm{D}} ; 31,0^{\mathrm{E}, \mathrm{F}}$ \\
\hline Laranja & $25,1^{\mathrm{G}} ; 11,9^{\mathrm{H}} ;$ & $10,2^{\mathrm{G}} ; 14,5^{\mathrm{H}} ;$ & $4,3^{\mathrm{G}} ; 2,2^{\mathrm{H}} ;$ \\
& $9,2^{\prime}$ & $10,5^{\prime}$ & $0,84^{\prime}$
\end{tabular}

Fonte - A ROJA E NEVES, 2002; B DEEPA et al., 2011; ' PEREIRA, 2010; D OLIVEIRA, 2010; E KELLEY et al., 2004; ${ }^{F}$ HILL et al., 1998; ' KIM et al., 2015; ' ${ }^{H}$ SÁNCHEZ et al., 2014; ' BENELLI, 2010. 


\subsection{Ensaios de sorção dos contaminantes}

5.2.1 Sistema Seco geral e por granulometria

As figuras 31 e 32 apresentam os resultados de sorção em sistema seco, sendo que, a 31 representa a sorção por tempo determinado, e a 32 a média desses resultados.

O sistema de sorção desempenhou melhor eficiência em óleo diesel do que em gasolina para todos os biossorventes, havendo maior sorção após decorrido 60 minutos. Apenas a laranja obteve seu melhor rendimento em 45 minutos, quando atingiu o equilíbrio no sistema, conforme figura 31. A banana sorveu em média 1,03 $( \pm 0,07)$ gadsorvato/gbiossorvente de óleo diesel e $0,61( \pm 0,04)$ gadsorvato/gbiossorvente de gasolina; o coco sorveu 0,92 $( \pm 0,09) \mathrm{g} / \mathrm{g}$ de óleo diesel e $0,42( \pm 0,04) \mathrm{g} / \mathrm{g}$ de gasolina; e a laranja $1,45( \pm 0,04) \mathrm{g} / \mathrm{g}$ em óleo diesel e $1,26( \pm 0,06) \mathrm{g} / \mathrm{g}$ em gasolina (tabela 12 e figura32).

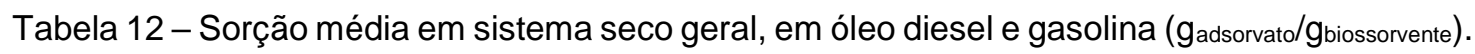

\begin{tabular}{lcc}
\hline & Óleo diesel $\mathbf{( g / g )}$ & Gasolina $\mathbf{( g / g )}$ \\
\hline Banana & $1,03( \pm 0,07)$ & $0,61( \pm 0,04)$ \\
\hline Coco & $0,92( \pm 0,09)$ & $0,42( \pm 0,04)$ \\
\hline Laranja & $1,45( \pm 0,04)$ & $1,26( \pm 0,06)$ \\
\hline
\end{tabular}

Fonte - autora da dissertação. 
Figura 31 - Sorção em óleo diesel e gasolina via sistema seco geral (gadsorvato/g giossorvente).

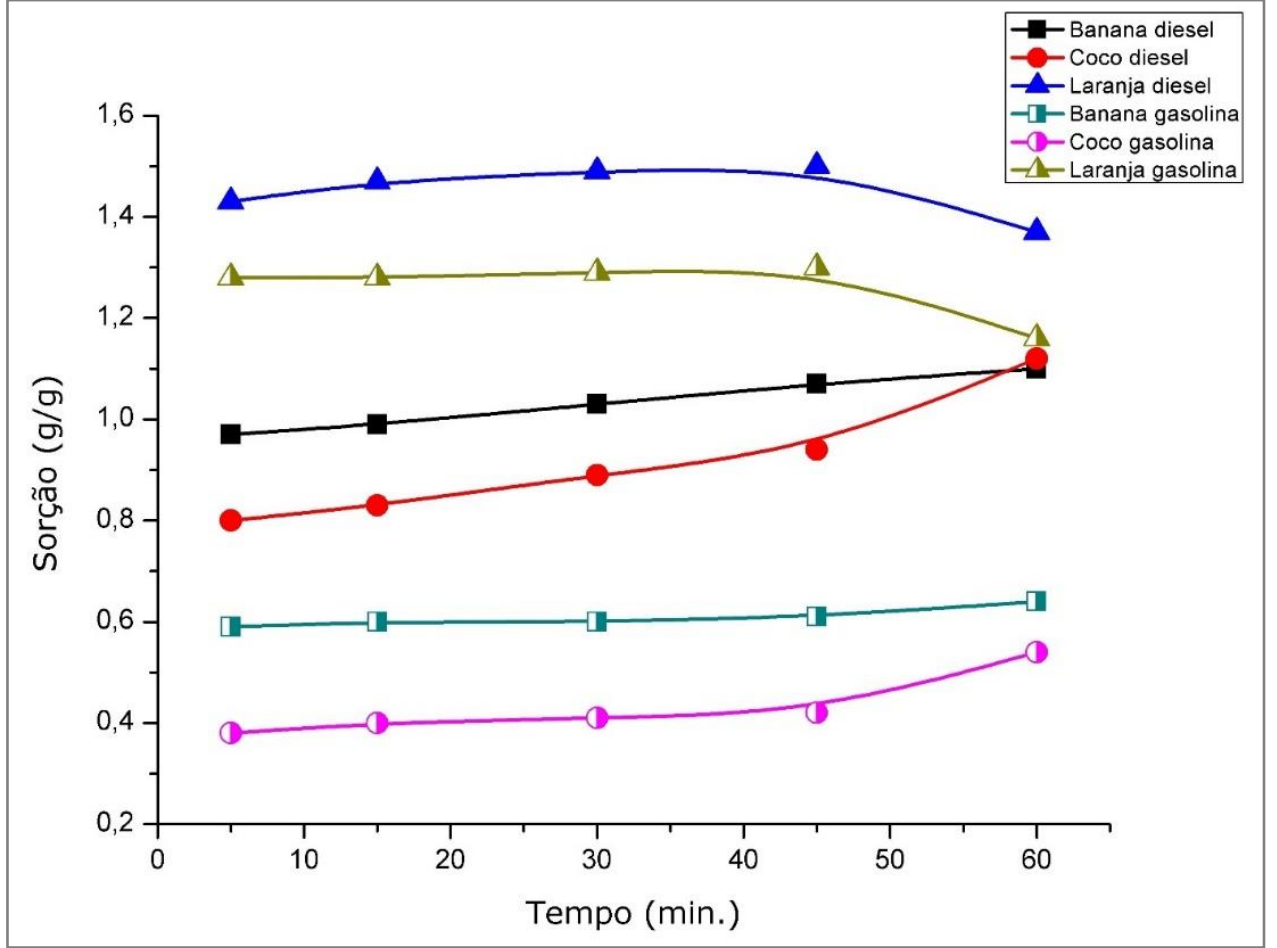

Fonte - autora da dissertação.

Figura 32 - Sorção média em óleo diesel (D) e gasolina (G) via sistema seco geral (gadsorvato/g $/$ biossorvente).

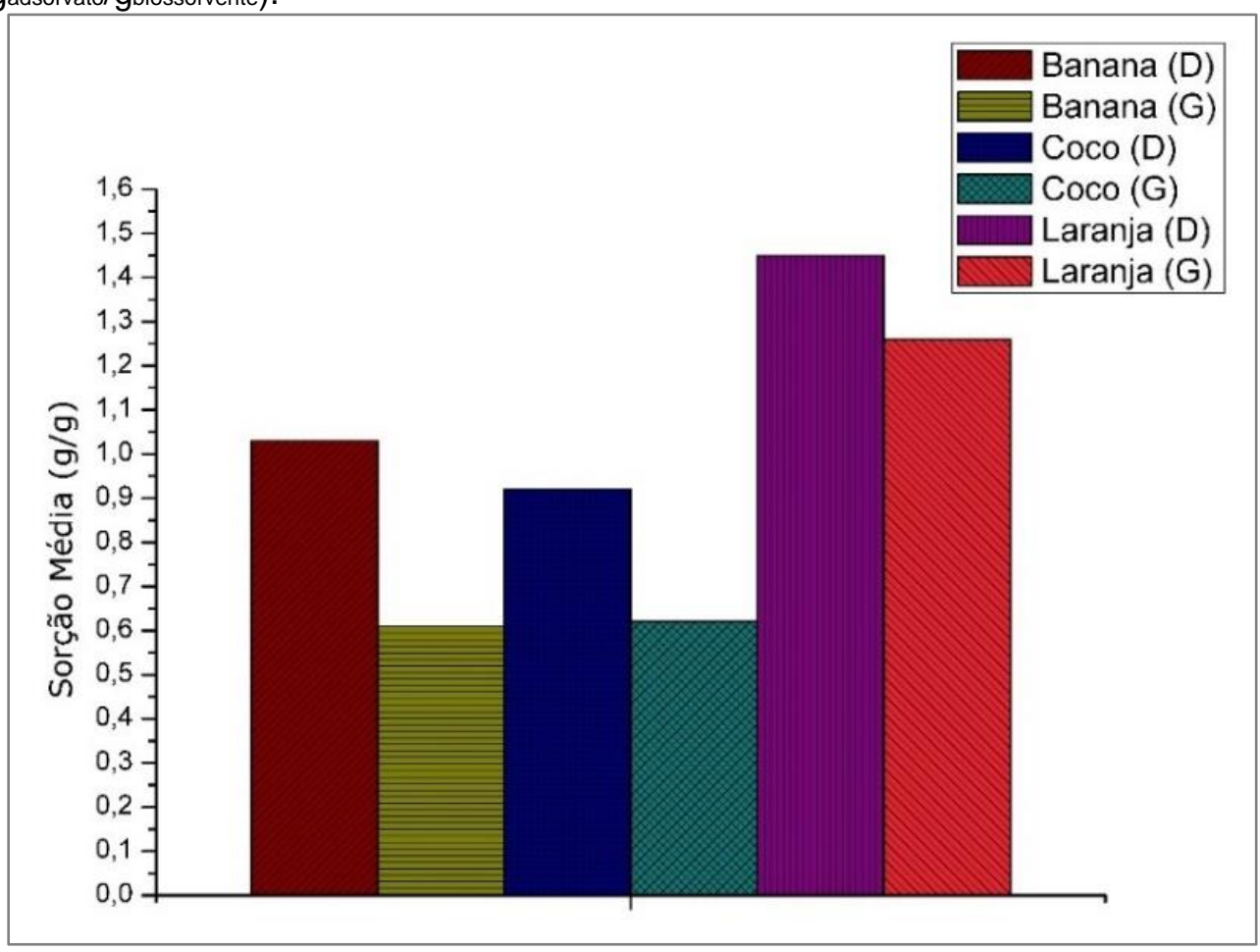

Fonte - autora da dissertação. 
Neste sentido, os três biossorventes foram eficientes, a laranja em primeiro, seguido da banana e do coco. Em média para o óleo diesel, ela sorveu em \% mássica, cerca de $40,78 \%$ a mais do que a banana e $57,61 \%$ a mais do que o coco. Para a gasolina, a laranja sorveu cerca de $106,56 \%$ a mais do que a banana e $200,00 \%$ a mais do que o coco.

Resultados semelhantes em relação as fibras de coco foram apresentados por Oliveira (2010), nesta pesquisa a média de sorção foi de $0,76( \pm 0,16) \mathrm{g} / \mathrm{g}$ em óleo diesel. Segundo o autor, a penetração do óleo no interior do biossorvente é inversamente proporcional à sua viscosidade. Assim, o óleo diesel apresentou maior sorção pelos biossorventes, devido a aderência na superfície do material e dentro dos poros durante a drenagem. Já a gasolina, com menor viscosidade em relação ao diesel, é liberada pelo biossorvente com mais facilidade, diminuindo assim sua eficiência. Portanto, é esperado menor sorção da gasolina em comparação ao óleo diesel devido suas viscosidades distintas.

Embora o coco tenha obtido os melhores resultados nos testes de hidrofobicidade e flutuabilidade, obteve a pior sorção dos contaminantes, pode-se associar este fato com sua forma física em fibras utilizada neste ensaio, segundo estudos de Annunciado (2005), os biossorventes desempenham maior sorção quanto menor a granulometria. Por sua vez a laranja obteve o pior resultado no teste de flutuabilidade, porém desempenhou ótima sorção. Como observado nas microscopias, a laranja é o material que possui maior quantidade de poros, o que contribuiu para este fator.

Para determinação da influência granulométrica na sorção dos contaminantes, foi realizado o mesmo ensaio em sistema seco para cada tamanho de grão dos biossorventes, sendo $<0,25,0,25,0,50$ e $0,84 \mathrm{~mm}$, com teste em óleo diesel e em gasolina (figuras de 33 a 35 ). 
Figura 33 - Sorção em óleo diesel (D) e gasolina $(G)$ via sistema seco, por granulometria do biossorvente banana (gadsorvato/gbiossorvente).

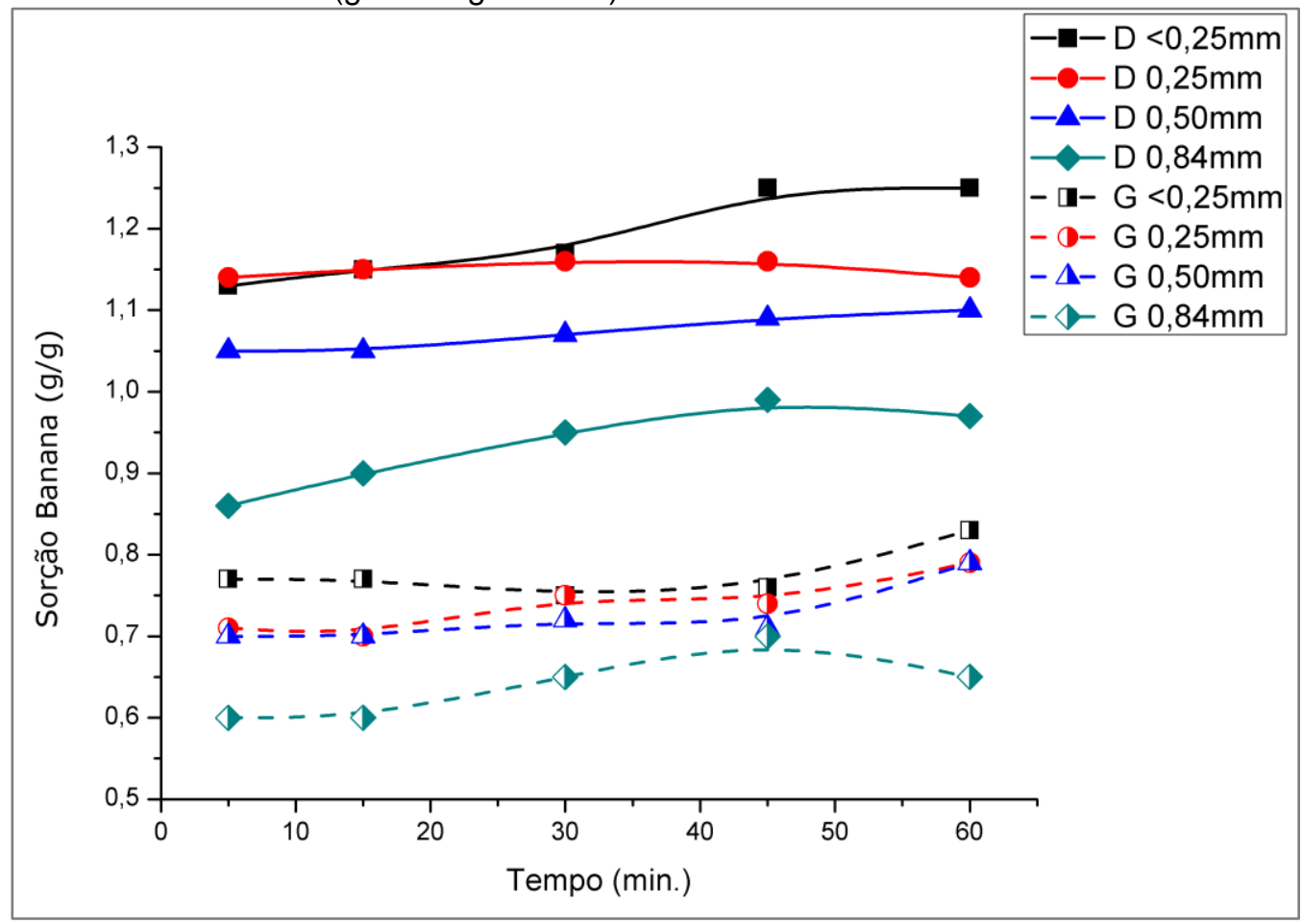

Fonte - autora da dissertação.

Figura 34 - Sorção em óleo diesel (D) e gasolina (G) via sistema seco, por granulometria do biossorvente coco (gadsorvato/g biossorvente). .

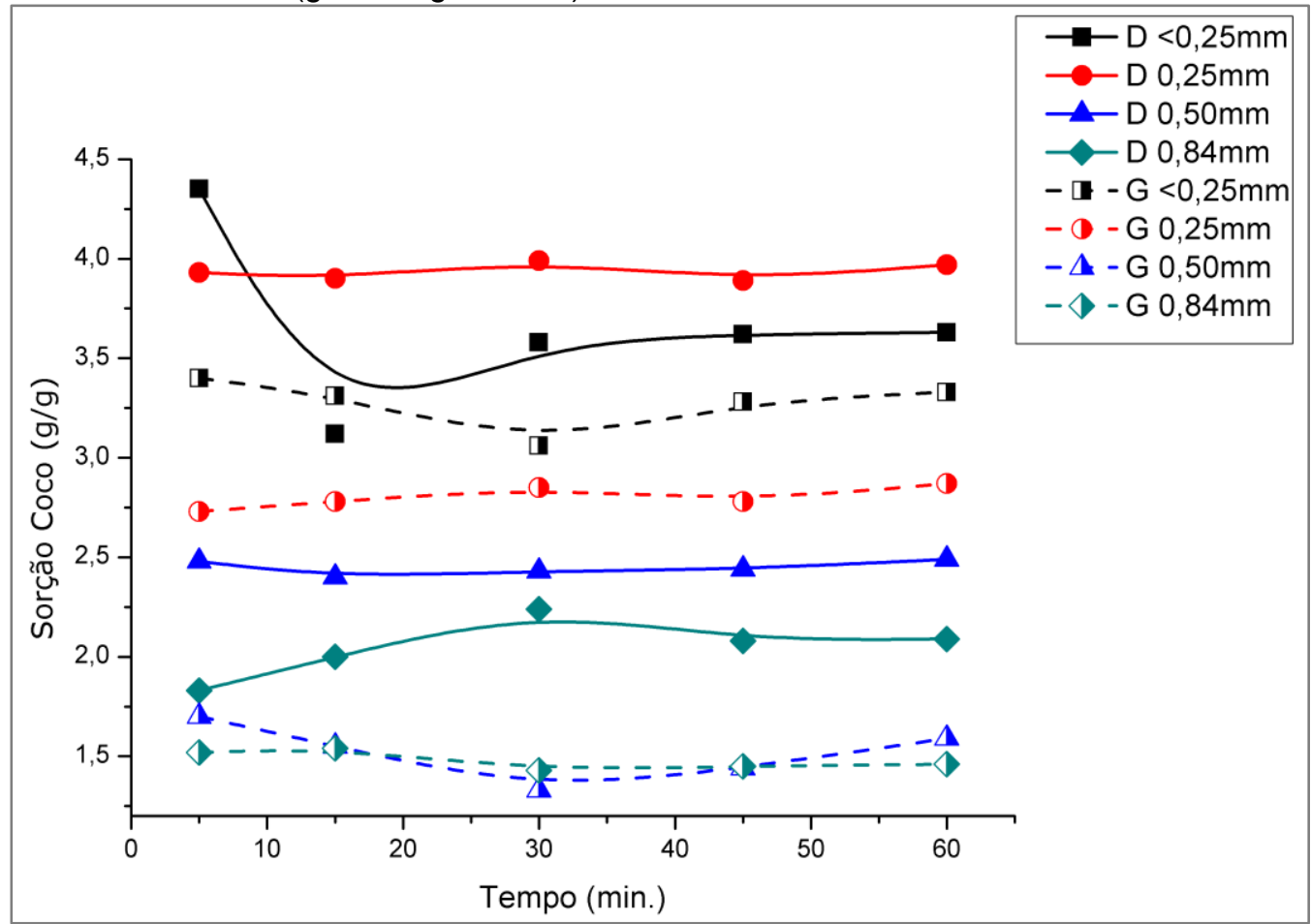

Fonte - autora da dissertação. 
Figura 35 - Sorção em óleo diesel (D) e gasolina (G) via sistema seco, por granulometria do biossorvente laranja ( $g_{\text {adsorvato }} / g_{\text {biossorvente) }}$.

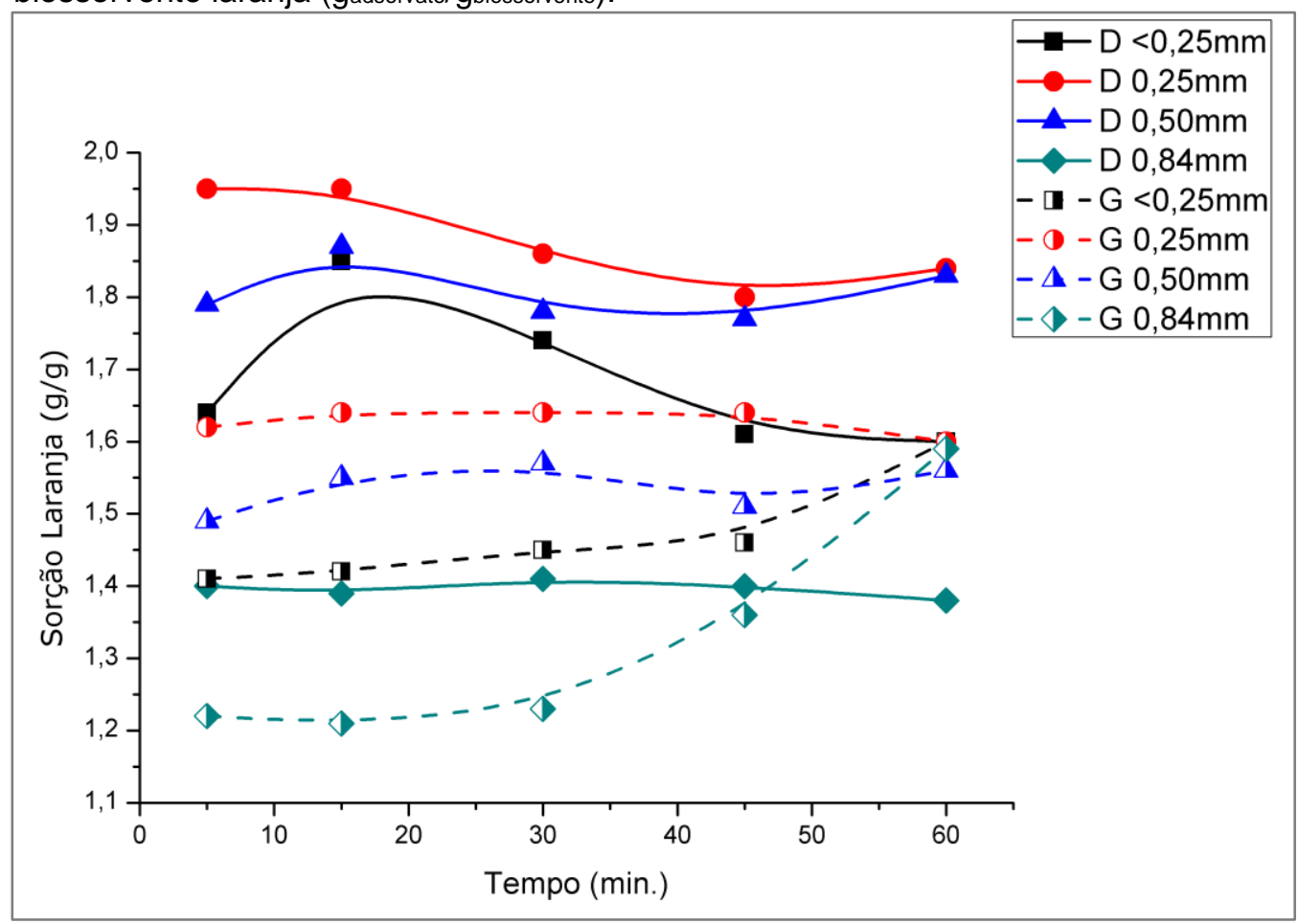

Fonte - autora da dissertação.

Os resultados demonstram que as granulometrias menores foram mais eficientes tanto em sorção de óleo diesel, quanto de gasolina. Nesse caso, o melhor tempo de sorção variou pouco entre 5 e 60 minutos, assim pode-se ter boa eficiência do material entre 5 a 15 minutos. Para a granulometria de $0,25 \mathrm{~mm}$, a banana sorveu em média $1,15( \pm 0,05) \mathrm{g} / \mathrm{g}$ de óleo diesel e $0,74( \pm 0,02) \mathrm{g} / \mathrm{g}$ de gasolina; o coco sorveu $3,94( \pm 0,06) \mathrm{g} / \mathrm{g}$ de óleo diesel e 2,80 $( \pm 0,11) \mathrm{g} / \mathrm{g}$ de gasolina; e a laranja 1,88 $( \pm 0,05)$ em óleo diesel e 1,63 $( \pm 0,03)$ em gasolina (tabela 13 e figura 36$)$.

Tabela 13 - Sorção média em sistema seco para a granulometria de 0,25 mm, em óleo diesel e gasolina ( $g_{\text {adsorvato }} / \mathrm{g}_{\text {biossorvente). }}$.

\begin{tabular}{lcc}
\hline $\mathbf{0 , 2 5} \mathbf{~} \boldsymbol{m}$ & Óleo diesel $\mathbf{( g / g )}$ & Gasolina $\mathbf{( g / g )}$ \\
\hline Banana & $1,15( \pm 0,05)$ & $0,74( \pm 0,02)$ \\
\hline Coco & $3,94( \pm 0,06)$ & $2,80( \pm 0,11)$ \\
\hline Laranja & $1,88( \pm 0,05)$ & $1,63( \pm 0,03)$ \\
\hline
\end{tabular}

Fonte - autora da dissertação. 
Figura 36 - Sorção média em óleo diesel (A) e gasolina (B) via sistema seco, por granulometria (gadsorvato/g $/$ biossorvente).

A - Óleo diesel

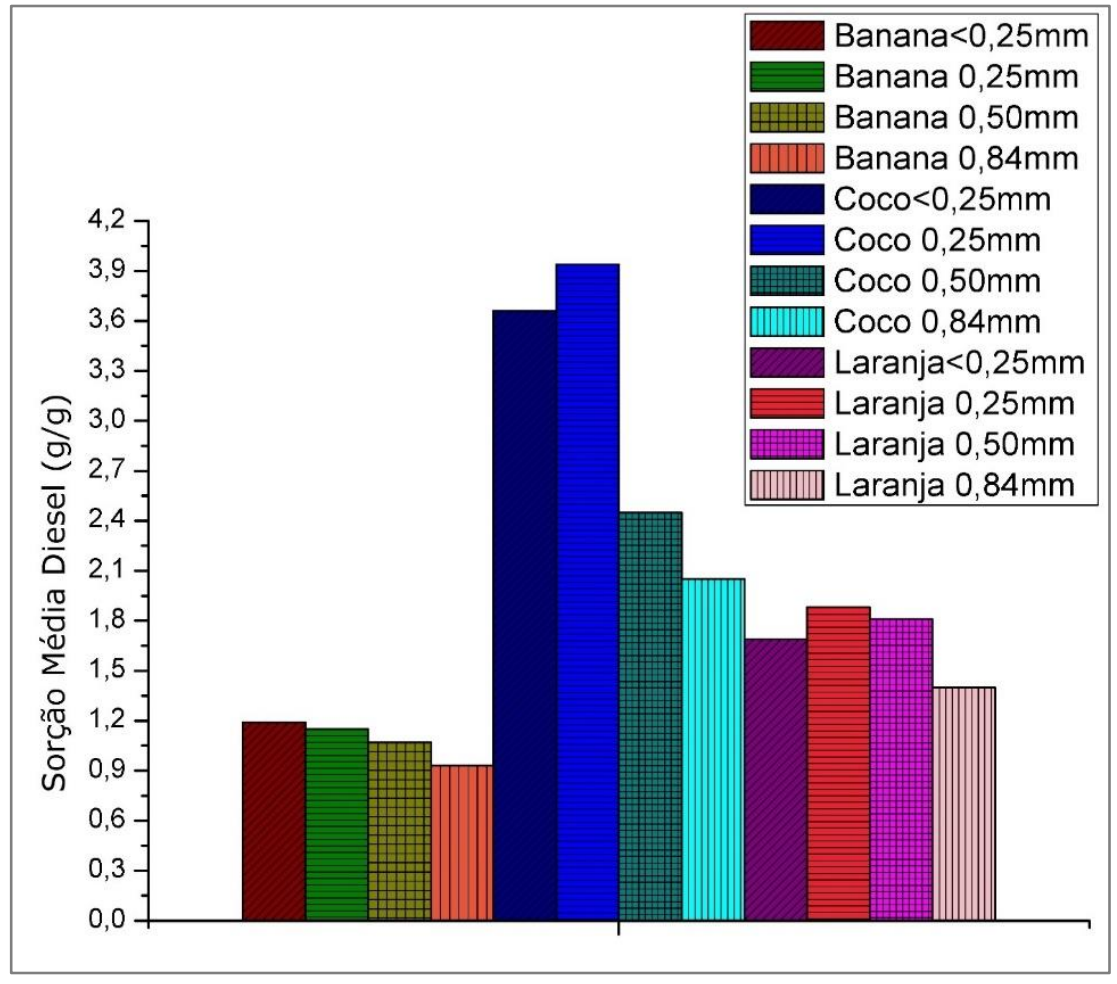

B - Gasolina

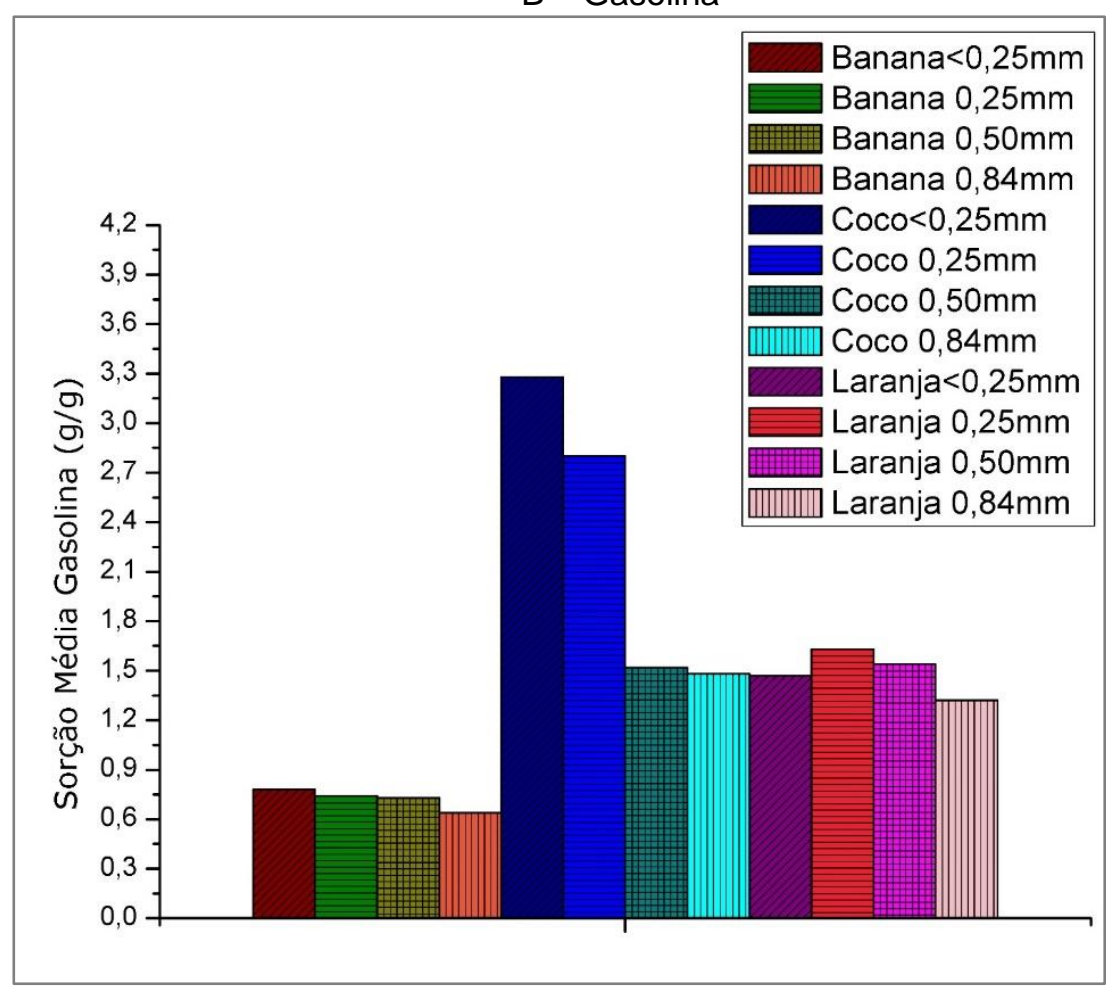

Fonte - autora da dissertação. 
Ainda comparando com a granulometria de $0,25 \mathrm{~mm}$, os resultados foram relevantes com o coco. A sorção média para o óleo diesel aumentou em mais de $300 \%$, quando comparado ao ensaio anterior, sem classificação granulométrica. Já com a laranja houve aumento de $29,66 \%$, seguido da banana com $11,65 \%$. Para a gasolina, houve igual aumento significativo com o coco, em mais de $500 \%$; seguido da laranja com $29,37 \%$ e a banana com $21,31 \%$, conforme tabela 14 .

Tabela 14 - Comparativo entre a sorção do sistema seco geral e por granulometria, em óleo diesel e gasolina (gadsorvato/g biossorvente).

\begin{tabular}{|c|c|c|c|c|c|c|}
\hline & $\begin{array}{l}\text { Geral } \\
(\mathrm{g} / \mathrm{g})\end{array}$ & Gran. & $\begin{array}{c}\text { Aumento (\% } \\
\text { mássica) }\end{array}$ & $\begin{array}{l}\text { Geral } \\
(g / g)\end{array}$ & $\begin{array}{l}\text { Gran. } \\
(g / g)\end{array}$ & $\begin{array}{c}\text { Aumento(\% } \\
\text { mássica) }\end{array}$ \\
\hline Banana & \multicolumn{3}{|c|}{ Óleo diesel } & \multicolumn{3}{|c|}{ Gasolina } \\
\hline$<0,25 \mathrm{~mm}$ & \multirow{4}{*}{$1,03( \pm 0,07)$} & $1,19( \pm 0,06)$ & 15,53 & \multirow{4}{*}{$0,61( \pm 0,04)$} & $0,78( \pm 0,04)$ & 27,87 \\
\hline $0,25 \mathrm{~mm}$ & & $1,15( \pm 0,05)$ & 11,65 & & $0,74( \pm 0,02)$ & 21,31 \\
\hline $0,50 \mathrm{~mm}$ & & $1,07( \pm 0,06)$ & 3,88 & & $0,73( \pm 0,03)$ & 19,67 \\
\hline $0,84 \mathrm{~mm}$ & & $0,93( \pm 0,04)$ & - & & $0,64( \pm 0,03)$ & 4,92 \\
\hline \multicolumn{7}{|l|}{ Coco } \\
\hline$<0,25 \mathrm{~mm}$ & \multirow{4}{*}{$0,92( \pm 0,09)$} & $3,66( \pm 0,07)$ & 297,82 & \multirow{4}{*}{$0,42( \pm 0,04)$} & $3,28( \pm 0,09)$ & 680,95 \\
\hline $0,25 \mathrm{~mm}$ & & $3,94( \pm 0,06)$ & 328,26 & & $2,80( \pm 0,11)$ & 566,67 \\
\hline $0,50 \mathrm{~mm}$ & & $2,45( \pm 0,08)$ & 166,30 & & $1,52( \pm 0,07)$ & 261,90 \\
\hline $0,84 \mathrm{~mm}$ & & $2,05( \pm 0,11)$ & 122,82 & & $1,48( \pm 0,08)$ & 252,38 \\
\hline \multicolumn{7}{|l|}{ Laranja } \\
\hline$<0,25 \mathrm{~mm}$ & \multirow{4}{*}{$1,45( \pm 0,04)$} & $1,69( \pm 0,06)$ & 16,55 & \multirow{4}{*}{$1,26( \pm 0,06)$} & $1,47( \pm 0,06)$ & 16,67 \\
\hline $0,25 \mathrm{~mm}$ & & $1,88( \pm 0,05)$ & 29,66 & & $1,63( \pm 0,03)$ & 29,37 \\
\hline $0,50 \mathrm{~mm}$ & & $1,81( \pm 0,05)$ & 24,83 & & $1,54( \pm 0,07)$ & 22,22 \\
\hline $0,84 \mathrm{~mm}$ & & $1,40( \pm 0,06)$ & - & & $1,32( \pm 0,09)$ & 4,76 \\
\hline
\end{tabular}

Fonte - autora da dissertação.

Annunciado (2005), demostrou em sua pesquisa, o efeito da classificação granulométrica de biossorventes para derivados do petróleo. Como resultado obteve considerável aumento da sorção, com a redução da granulometria em todas as fibras vegetais analisadas. Para o coco, este aumento chegou a $205 \%$, com sorção de até $5,4 \mathrm{~g} / \mathrm{g}$ de óleo contaminante. Este fator pode ser associado ao aumento da área de superfície específica, que ocorre com a redução da granulometria, potencializando assim o processo de sorção. 
Em contrapartida, nos estudos de Oliveira (2010), quando analisado a interação do biossorvente, tempo de exposição ao óleo contaminante e granulometria, observouse comportamento distinto para cada biossorvente em relação à sorção média de óleo, não estabelecendo um padrão único. Isso leva a crer que, tanto as fibras vegetais estudadas, quanto os processos de sorção, nesta pesquisa e em outras similares, têm suas particularidades distintas, desempenhando cada qual a sorção conforme suas características.

\subsubsection{Sistema Aquoso geral e por granulometria}

As figuras 37 e 38 apresentam os resultados de sorção em sistema aquoso, simulando derramamento em um corpo hídrico, tanto em sistema dinâmico, quanto em estático. Sendo que, a 37 representa a sorção por tempo determinado, e a 38 a média desses resultados.

Neste sistema, como no anterior, o óleo diesel permaneceu com maior sorção do que a gasolina; já os biossorventes desempenharam resultados distintos entre dinâmico e estático, não estabelecendo um padrão único. Porém o dinâmico em uma visão geral, apresentou sorção maior do que o estático na maioria dos casos, como observado na figura 37. 
Figura 37 - Sorção em óleo diesel e gasolina via sistema aquoso dinâmico (D) e estático (E) (gadsorvato/gbiossorvente).

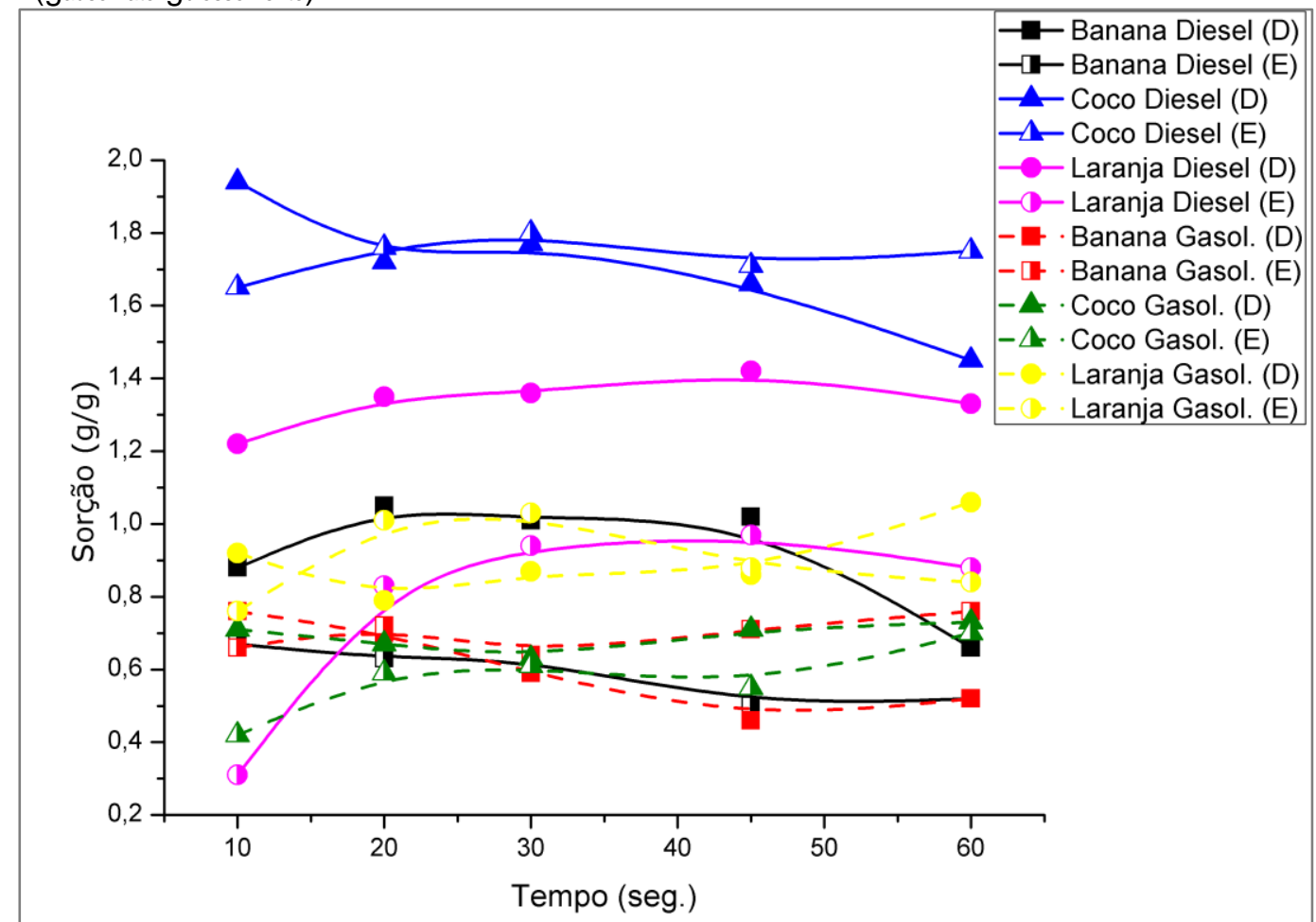

Fonte - autora da dissertação.

Para a média de resultados, a banana, coco e a laranja, sorveram em óleo diesel, sob sistema dinâmico, respectivamente $0,92( \pm 0,03) \mathrm{g} / \mathrm{g} ; 1,71( \pm 0,10) \mathrm{g} / \mathrm{g}$ e 1,34 $( \pm 0,05) \mathrm{g} / \mathrm{g}$; sob estático $0,59( \pm 0,03) \mathrm{g} / \mathrm{g} ; 1,73( \pm 0,11)$ e $0,79( \pm 0,05)$. Em gasolina foram $0,61( \pm 0,08) \mathrm{g} / \mathrm{g} ; 0,69( \pm 0,05) \mathrm{g} / \mathrm{g}$ e $0,90( \pm 0,02) \mathrm{g} / \mathrm{g}$ em sistema dinâmico; e 0,70 $( \pm 0,04) \mathrm{g} / \mathrm{g} ; 0,57( \pm 0,09) \mathrm{g} / \mathrm{g}$ e $0,90( \pm 0,07) \mathrm{g} / \mathrm{g}$ para estático, conforme tabela $15 \mathrm{e}$ figura 38.

Tabela 15 - Sorção média em sistema aquoso dinâmico e estático, em óleo diesel e gasolina (gadsorvato/gbiossorvente).

\section{Óleo diesel (g/g)}

Dinâmico
Estático

\begin{tabular}{lllll}
\hline Banana & $0,92( \pm 0,03)$ & $0,59( \pm 0,03)$ & $0,61( \pm 0,08)$ & $0,70( \pm 0,04)$ \\
\hline Coco & $1,71( \pm 0,10)$ & $1,73( \pm 0,11)$ & $0,69( \pm 0,05)$ & $0,57( \pm 0,09)$ \\
\hline Laranja & $1,34( \pm 0,05)$ & $0,79( \pm 0,05)$ & $0,90( \pm 0,02)$ & $0,90( \pm 0,07)$
\end{tabular}

Fonte - autora da dissertação.

\section{Gasolina (g/g)}

Dinâmico

Estático 
Figura 38 - Sorção média em óleo diesel (A) e gasolina (B) via sistema aquoso dinâmico (D) e estático (E) (gadsorvato/gbiossorvente).

A - Óleo diesel

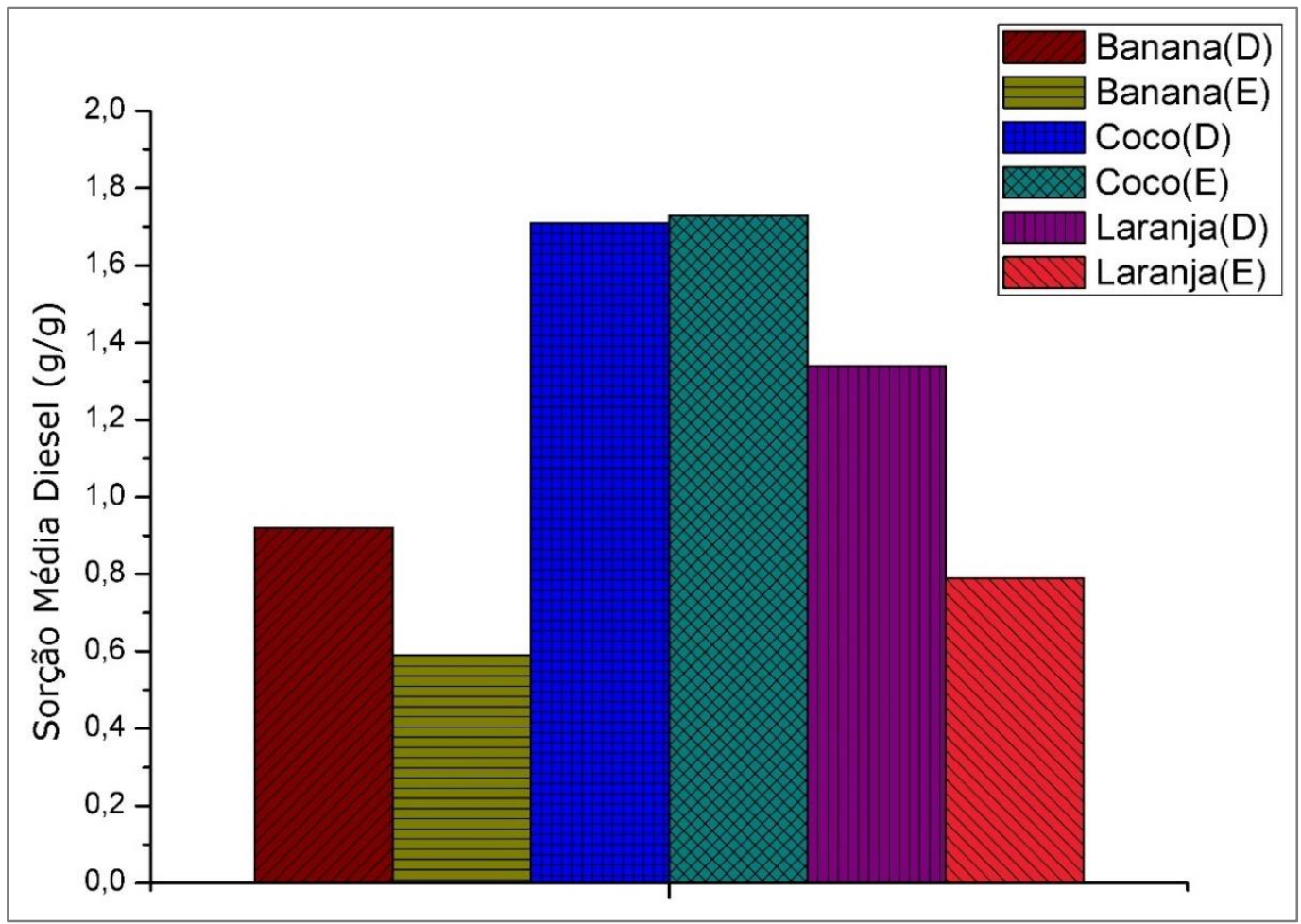

B - Gasolina

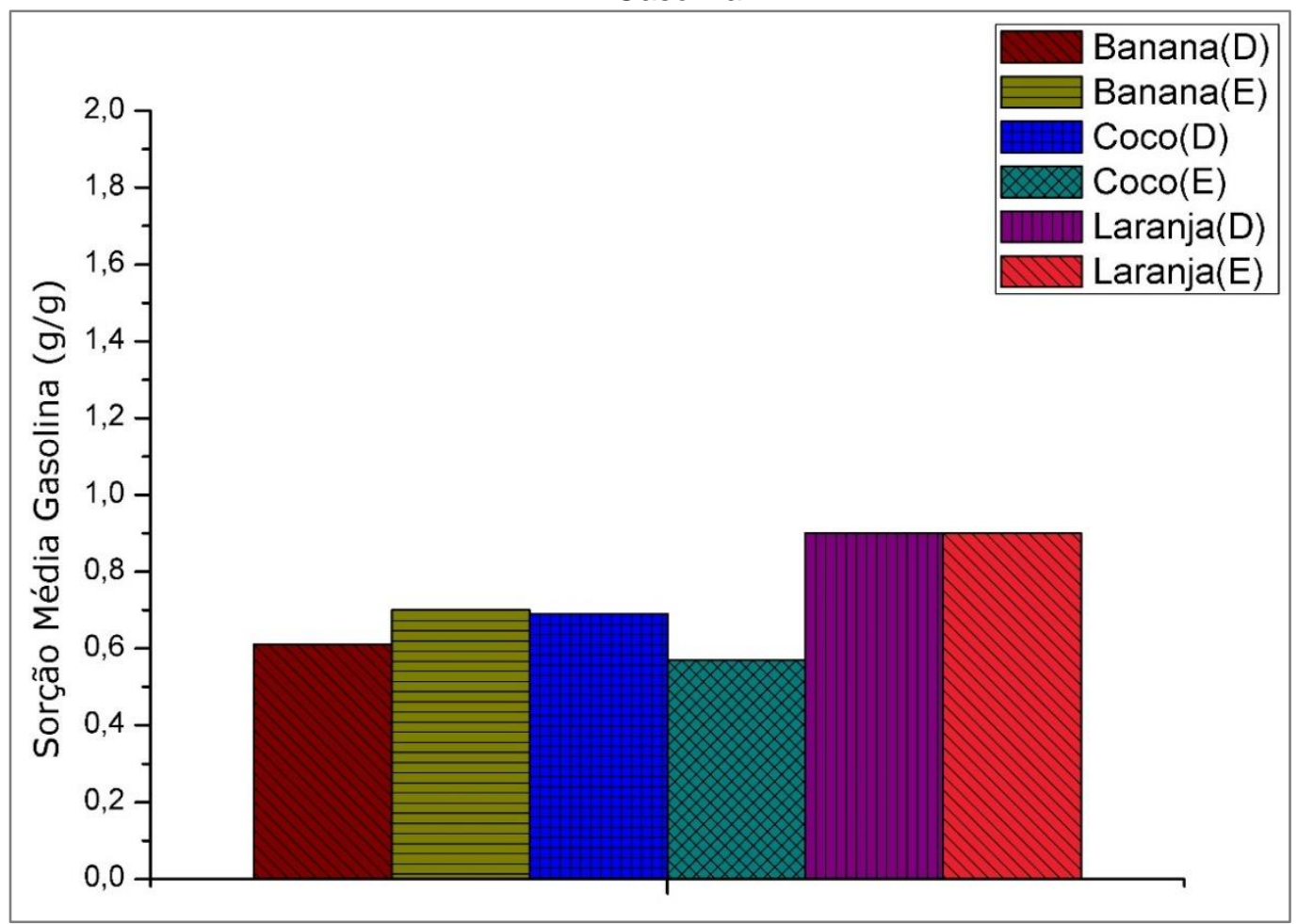

Fonte - autora da dissertação. 
Neste caso, para óleo diesel, o biossorvente que obteve melhor desempenho foi o coco, seguido da laranja e a banana. Ele sorveu em dinâmico cerca de 27,61\% a mais do que a laranja e $85,87 \%$ a mais do que a banana. Para o sistema estático o coco sorveu cerca de $119,00 \%$ a mais do que a laranja e $193,22 \%$ a mais para a banana.

Para gasolina o cenário muda um pouco, com o biossorvente da laranja com melhor desempenho. Em sistema dinâmico, ela sorveu cerca de $30,43 \%$ a mais do que o coco e $47,54 \%$ a mais do que a banana. Para estático a laranja sorveu cerca de $28,57 \%$ a mais do que o coco e $57,89 \%$ a mais do que a banana.

Neste estudo em sistema aquoso, também foi avaliado a sorção dos contaminantes sob as granulometrias que desempenharam melhor resultado apresentado anteriormente, sendo estas $<0,25 \mathrm{~mm}, 0,25 \mathrm{~mm}$ e $0,50 \mathrm{~mm}$. As figuras de 39 a 41 representam a sorção por tempo determinado e a 42 a média desses resultados.

Diferente do sistema aquoso geral, que se manteve relativamente constante em função do tempo, este, pôde-se observar aumento da sorção para os biossorventes da banana e da laranja. Já em relação ao desempenho sortivo, como no sistema seco, as granulometrias menores foram mais eficientes, mantendo melhor sorção entre $<0,25 \mathrm{~mm}$ e 0,25 mm, conforme figuras 39,40 e 41 . 
Figura 39 - Sorção em óleo diesel e gasolina via sistema aquoso dinâmico (D) e estático (E), por granulometria do biossorvente banana ( $g_{\text {adsorvato }} / g_{\text {biossorvente) }}$.

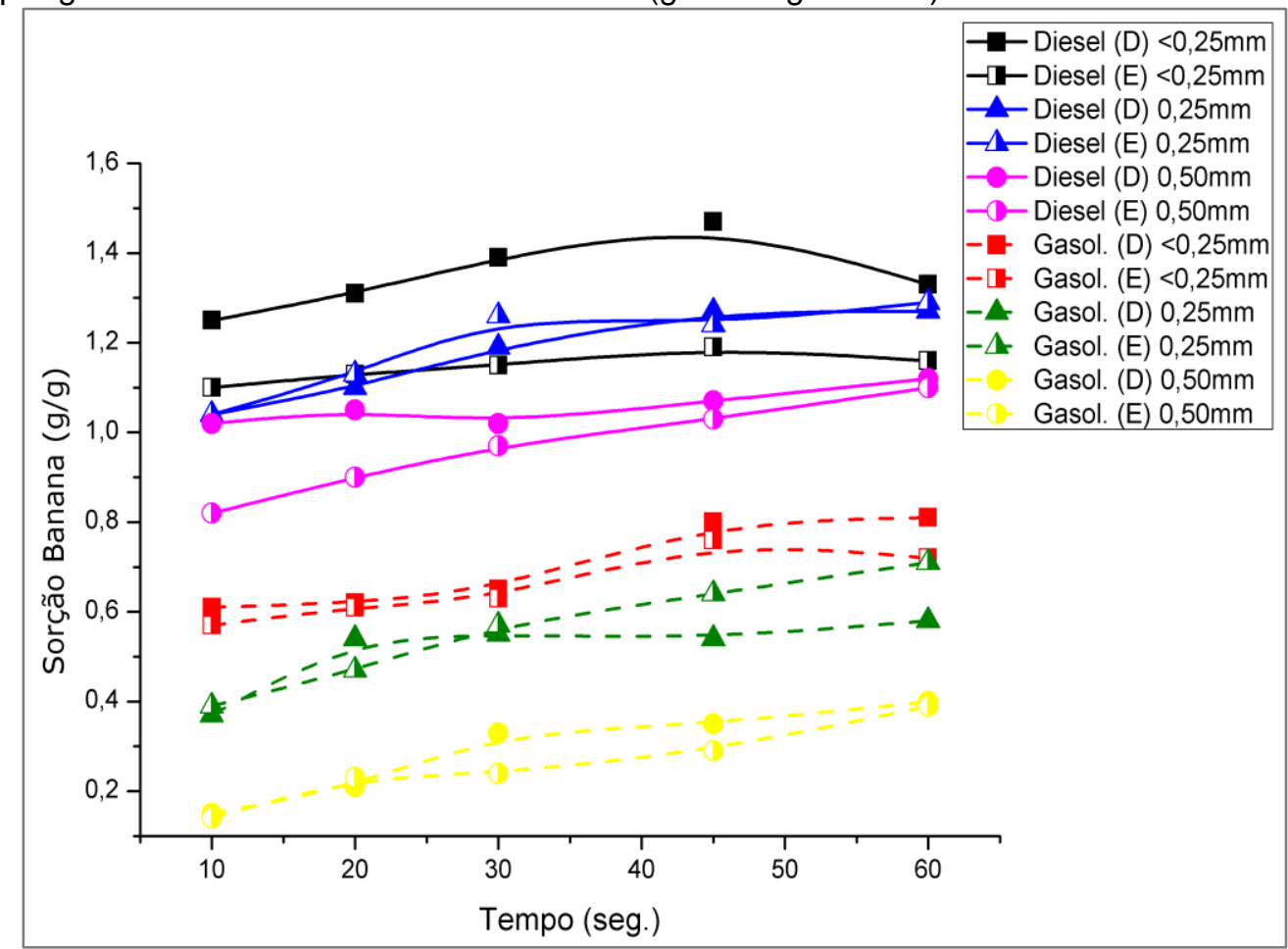

Fonte - autora da dissertação.

Figura 40 - Sorção em óleo diesel e gasolina via sistema aquoso dinâmico (D) e estático (E), por granulometria do biossorvente coco ( $g_{\text {adsorvato/gbiossorvente). }}$

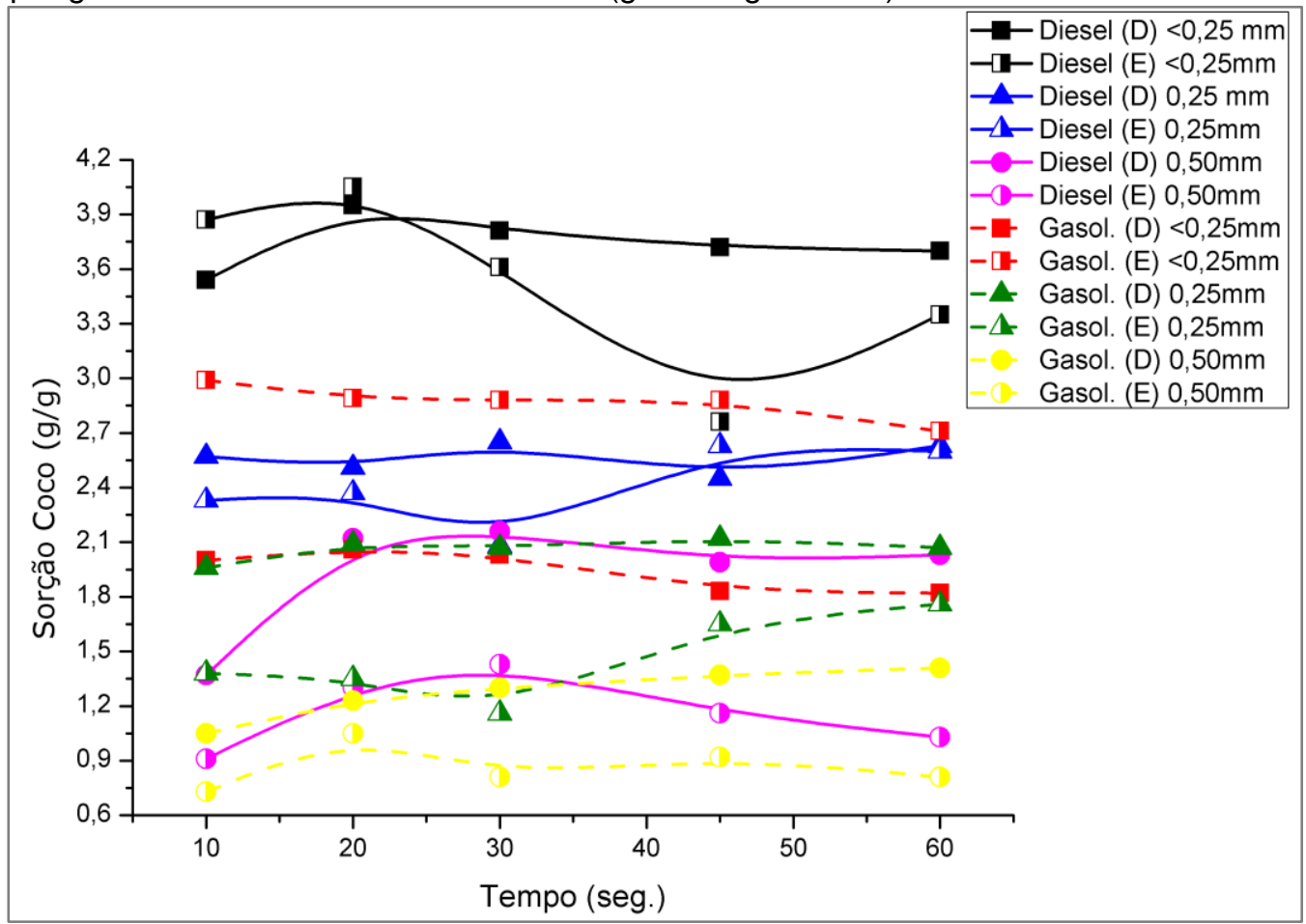

Fonte - autora da dissertação. 
Figura 41 - Sorção em óleo diesel (A) e gasolina (B) via sistema aquoso dinâmico (D) e estático (E), por granulometria do biossorvente laranja (gadsorvato/gbiossorvente).

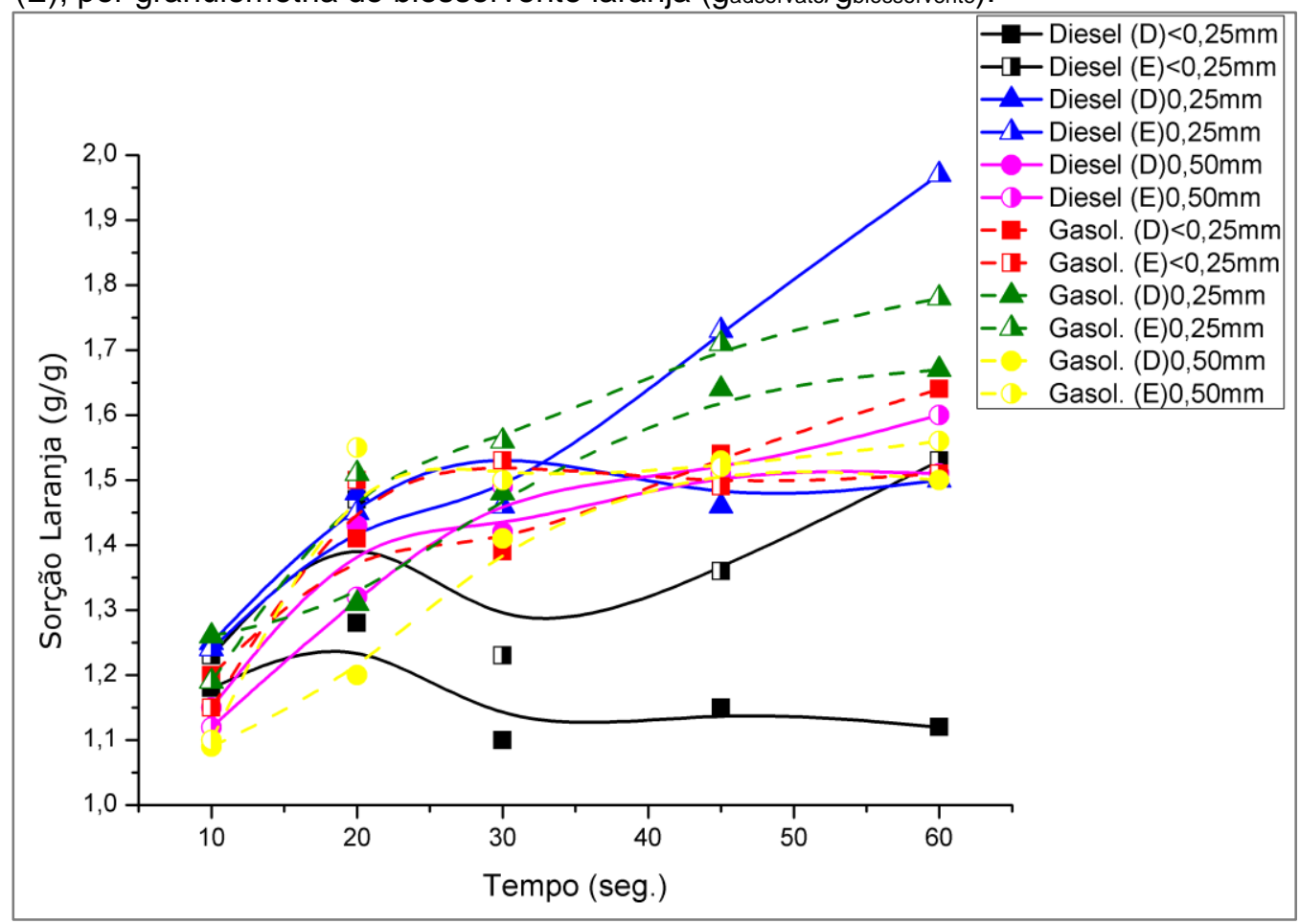

Fonte - autora da dissertação.

Para média de sorção de óleo diesel em sistema dinâmico, na granulometria de $0,25 \mathrm{~mm}$, os biossorventes da banana, coco e laranja, obtiveram respectivamente em média sorção de $1,17( \pm 0,03) \mathrm{g} / \mathrm{g} ; 2,56( \pm 0,12) \mathrm{g} / \mathrm{g}$ e $1,45( \pm 0,05) \mathrm{g} / \mathrm{g}$. Para estático $1,19( \pm 0,03) \mathrm{g} / \mathrm{g} ; 2,40( \pm 0,13) \mathrm{g} / \mathrm{g}$ e $1,57( \pm 0,03) \mathrm{g} / \mathrm{g}$. Para a gasolina em sistema dinâmico, a sorção da banana, coco e laranja, também em $0,25 \mathrm{~mm}$, ficou em 0,52 $( \pm 0,03) \mathrm{g} / \mathrm{g} ; 2,06( \pm 0,11) \mathrm{g} / \mathrm{g}$ e $1,47( \pm 0,06) \mathrm{g} / \mathrm{g}$. Para estático $0,56( \pm 0,04) \mathrm{g} / \mathrm{g} ; 1,46$ $( \pm 0,09) \mathrm{g} / \mathrm{g}$ e $1,55( \pm 0,04) \mathrm{g} / \mathrm{g}$, conforme tabela 16 e figura 42.

Tabela 16 - Sorção média em sistema aquoso para a granulometria de $0,25 \mathrm{~mm}$, dinâmico e estático, em óleo diesel e gasolina ( $g_{\text {adsorvato }} / g_{\text {biossorvente) }}$.

$0,25 \mathrm{~mm}$

Óleo diesel (g/g)

Gasolina (g/g)

Dinâmico Estático Dinâmico Estático

\begin{tabular}{lllll}
\hline Banana & $1,17( \pm 0,03)$ & $1,19( \pm 0,03)$ & $0,52( \pm 0,03)$ & $0,56( \pm 0,04)$ \\
\hline Coco & $2,56( \pm 0,12)$ & $2,40( \pm 0,13)$ & $2,06( \pm 0,11)$ & $1,46( \pm 0,09)$ \\
\hline Laranja & $1,45( \pm 0,05)$ & $1,57( \pm 0,03)$ & $1,47( \pm 0,06)$ & $1,55( \pm 0,04)$
\end{tabular}

Fonte - autora da dissertação. 
Figura 42 - Sorção média em óleo diesel (A) e gasolina (B) via sistema aquoso dinâmico (D) e estático (E), por granulometria (gadsorvato/gbiossorvente).

\section{A - Óleo diesel}

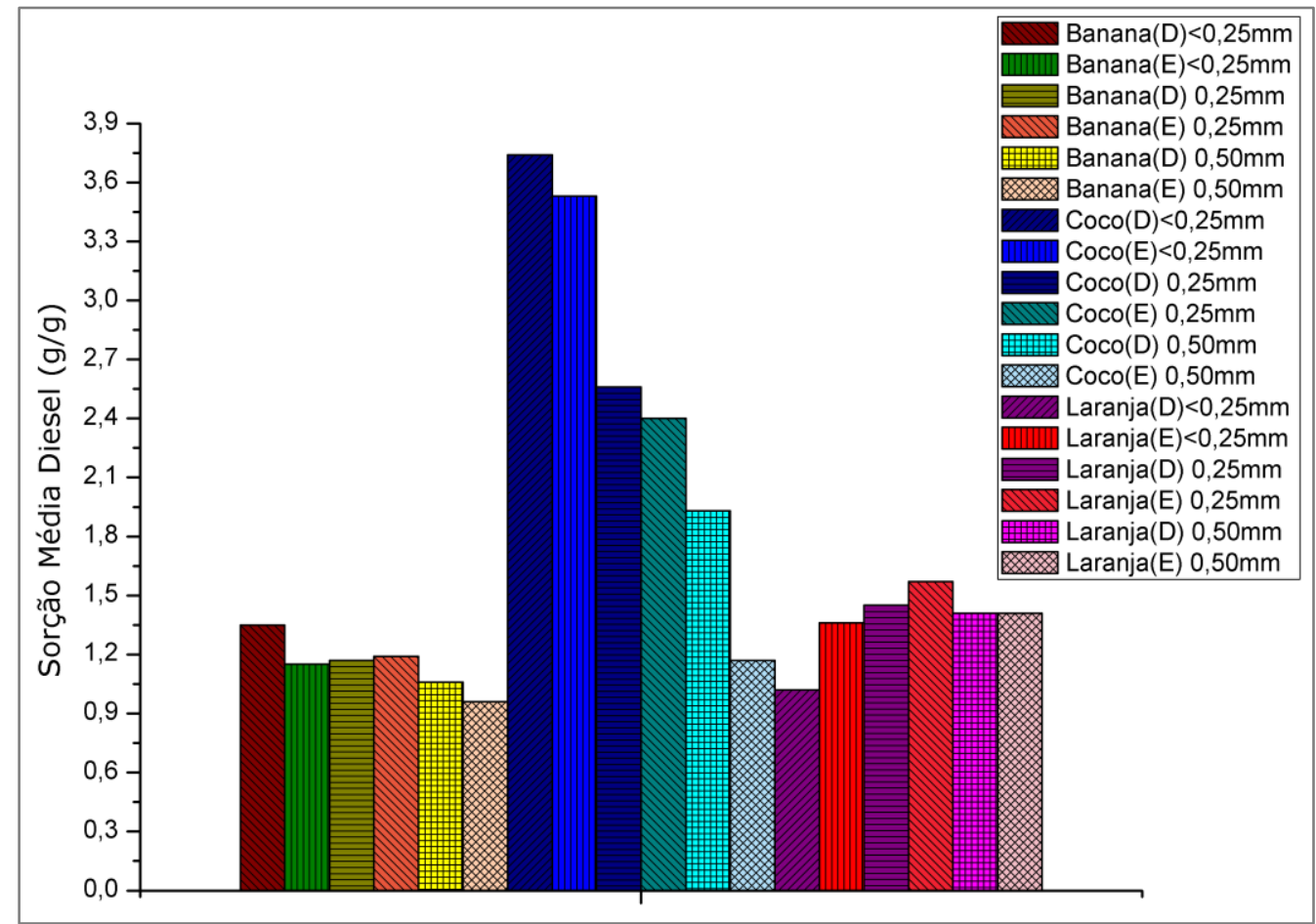

B - Gasolina

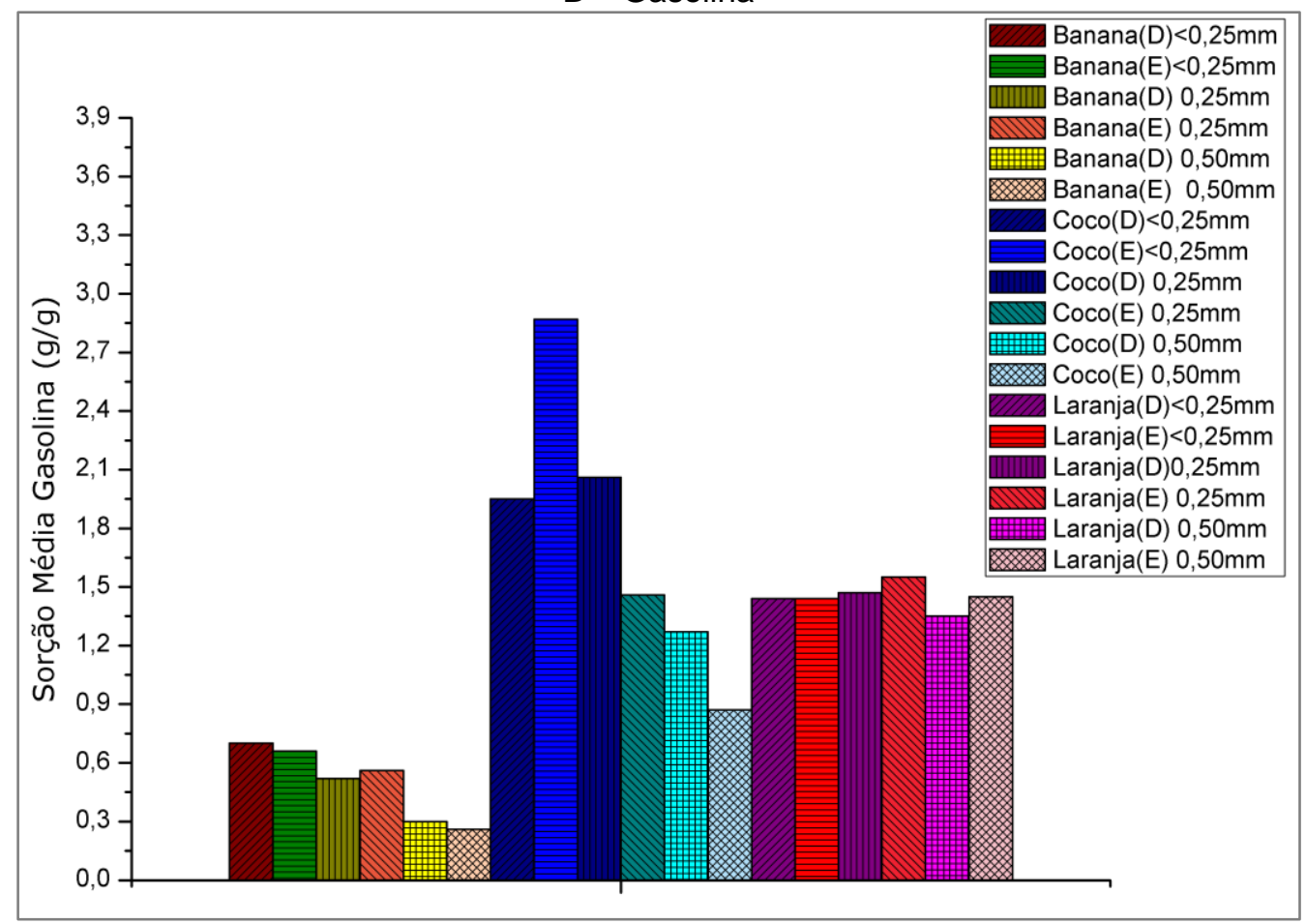

Fonte - autora da dissertação. 
Neste caso, a relação sistema dinâmico versus estático, obteve algumas variâncias. A banana se manteve relativamente semelhante; $\mathrm{O}$ coco, em sistema estático se manteve com menor sorção na maioria dos ensaios, exceto na granulometria em $0,25 \mathrm{~mm}$; para a laranja, o sistema estático ficou igual ou sensivelmente superior ao dinâmico.

Em relação a eficiência do sistema, o biossorvente do coco, assim como apresentado em sistema seco, obteve o melhor desempenho, seguido da laranja e da banana. Sua sorção média para o óleo diesel, em sistema dinâmico e 0,25 mm, aumentou em 49,71\%, quando comparado ao ensaio anterior, sem separação granulométrica. Já a laranja ficou em segundo com aumento de $8,21 \%$, seguido da banana com $27,17 \%$. Para o estático, o coco obteve igual aumento significativo, em $38,73 \%$, seguido da laranja com $98,73 \%$ e a banana com $101,70 \%$, conforme dados da tabela 17.

Tabela 17 - Comparativo entre a sorção do sistema geral e por granulometria (dinâmico e estático) em óleo diesel (gadsorvato/g biossorvente).

\begin{tabular}{|c|c|c|c|c|c|c|}
\hline & $\begin{array}{l}\text { Geral } \\
(\mathrm{g} / \mathrm{g})\end{array}$ & $\begin{array}{l}\text { Gran. } \\
(\mathrm{g} / \mathrm{g})\end{array}$ & $\begin{array}{c}\text { Aumento (\% } \\
\text { mássica) }\end{array}$ & $\begin{array}{l}\text { Geral } \\
(\mathrm{g} / \mathrm{g})\end{array}$ & $\begin{array}{l}\text { Gran. } \\
(g / g)\end{array}$ & $\begin{array}{c}\text { Aumento (\% } \\
\text { mássica) }\end{array}$ \\
\hline Banana & \multicolumn{3}{|c|}{ Sistema dinâmico } & \multicolumn{3}{|c|}{ Sistema estático } \\
\hline$<0,25 \mathrm{~mm}$ & \multirow{3}{*}{$0,92( \pm 0,03)$} & $1,35( \pm 0,04)$ & 46,74 & \multirow{3}{*}{$0,59( \pm 0,03)$} & $1,15( \pm 0,06)$ & 94,92 \\
\hline $0,25 \mathrm{~mm}$ & & $1,17( \pm 0,03)$ & 27,17 & & $1,19( \pm 0,03)$ & 101,70 \\
\hline $0,50 \mathrm{~mm}$ & & $1,06( \pm 0,04)$ & 15,22 & & $0,96( \pm 0,05)$ & 62,71 \\
\hline \multicolumn{7}{|l|}{ Coco } \\
\hline$<0,25 \mathrm{~mm}$ & \multirow{3}{*}{$1,71( \pm 0,10)$} & $3,74( \pm 0,11)$ & 118,71 & \multirow{3}{*}{$1,73( \pm 0,11)$} & $3,53( \pm 0,12)$ & 104,05 \\
\hline $0,25 \mathrm{~mm}$ & & $2,56( \pm 0,12)$ & 49,71 & & $2,40( \pm 0,13)$ & 38,73 \\
\hline $0,50 \mathrm{~mm}$ & & $1,93( \pm 0,09)$ & 12,28 & & $1,17( \pm 0,11)$ & - \\
\hline \multicolumn{7}{|l|}{ Laranja } \\
\hline$<0,25 \mathrm{~mm}$ & \multirow{3}{*}{$1,34( \pm 0,05)$} & $1,02( \pm 0,04)$ & - & \multirow{3}{*}{$0,79( \pm 0,05)$} & $1,36( \pm 0,04)$ & 72,15 \\
\hline $0,25 \mathrm{~mm}$ & & $1,45( \pm 0,05)$ & 8,21 & & $1,57( \pm 0,03)$ & 98,73 \\
\hline $0,50 \mathrm{~mm}$ & & $1,41( \pm 0,06)$ & 5,22 & & $1,41( \pm 0,05)$ & 78,48 \\
\hline
\end{tabular}

Fonte - autora da dissertação. 
Para sorção média em gasolina, em sistema dinâmico em $<0,25 \mathrm{~mm}$, o biossorvente coco aumentou em 182,61\%, quando comparado ao ensaio anterior, sem separação granulométrica. Já a laranja ficou em segundo com aumento de 60,00\%, seguido da banana, com $14,75 \%$. Para o estático, o coco obteve igual aumento significativo, em $403,51 \%$, seguido da laranja com $60,00 \%$ (tabela 18 ).

Tabela 18 - Comparativo entre a sorção do sistema aquoso geral e por granulometria (dinâmico e estático) em gasolina (gadsorvato/gbiossorvente).

\begin{tabular}{|c|c|c|c|c|c|c|}
\hline & Geral & Gran. & $\begin{array}{l}\text { Aumento (\% } \\
\text { mássica) }\end{array}$ & $\begin{array}{l}\text { Geral } \\
(g / g)\end{array}$ & $\begin{array}{l}\text { Gran. } \\
(g / g)\end{array}$ & $\begin{array}{c}\text { Aumento (\% } \\
\text { mássica) }\end{array}$ \\
\hline Banana & \multicolumn{3}{|c|}{ Sistema dinâmico } & \multicolumn{3}{|c|}{ Sistema estático } \\
\hline$<0,25 \mathrm{~mm}$ & \multirow{3}{*}{$0,61( \pm 0,08)$} & $0,70( \pm 0,04)$ & 14,75 & \multirow{3}{*}{$0,70( \pm 0,04)$} & $0,66( \pm 0,03)$ & - \\
\hline $0,25 \mathrm{~mm}$ & & $0,52( \pm 0,03)$ & - & & $0,56( \pm 0,04)$ & - \\
\hline $0,50 \mathrm{~mm}$ & & $0,30( \pm 0,03)$ & - & & $0,26( \pm 0,03)$ & - \\
\hline \multicolumn{7}{|l|}{ Coco } \\
\hline$<0,25 \mathrm{~mm}$ & \multirow{3}{*}{$0,69( \pm 0,05)$} & $1,95( \pm 0,08)$ & 182,61 & \multirow{3}{*}{$0,57( \pm 0,09)$} & $2,87( \pm 0,14)$ & 403,51 \\
\hline $0,25 \mathrm{~mm}$ & & $2,06( \pm 0,11)$ & 198,55 & & $1,46( \pm 0,09)$ & 156,14 \\
\hline $0,50 \mathrm{~mm}$ & & $1,27( \pm 0,12)$ & 84,06 & & $0,87( \pm 0,10)$ & 52,63 \\
\hline \multicolumn{7}{|l|}{ Laranja } \\
\hline$<0,25 \mathrm{~mm}$ & \multirow{3}{*}{$0,90( \pm 0,02)$} & $1,44( \pm 0,07)$ & 60,00 & \multirow{3}{*}{$0,90( \pm 0,07)$} & $1,44( \pm 0,05)$ & 60,00 \\
\hline $0,25 \mathrm{~mm}$ & & $1,47( \pm 0,06)$ & 63,33 & & $1,55( \pm 0,04)$ & 72,22 \\
\hline $0,50 \mathrm{~mm}$ & & $1,35( \pm 0,04)$ & 50,00 & & $1,45( \pm 0,06)$ & 61,11 \\
\hline
\end{tabular}

Fonte - autora da dissertação.

Na pesquisa de Costa et al., (2012), foram realizados ensaios com o pó das cascas de banana como biossorvente de óleo diesel e gasolina. Para esta metodologia, a sorção foi mensurada em porcentagem, e obteve extração de até $100 \%$ do contaminante da água.

No estudo de Borges (2015), quando analisada a sorção de fibras de bananeira, em uma solução com petróleo, o resultado atingiu sorção de $3,7 \mathrm{~g} / \mathrm{g}$ de contaminante e demonstrou viabilidade para o uso deste material. 


\subsection{Isotermas de sorção em emulsões óleo/água}

Neste subcapítulo são apresentados os resultados do sistema de sorção das isotermas de Langmuir e Freundlich, primeiramente dos biossorventes em sistema geral e posterior separados por granulometria, ambos avaliados em óleo diesel. Assim, também foi possível verificar neste estudo, a capacidade sortiva dos materiais sob diferentes tamanhos de grãos.

\subsubsection{Sistema Geral}

Através da análise de regressão é possível estimar os parâmetros dos modelos de isotermas, podendo assim inferir sobre os tipos de mecanismos envolvidos nos processos de sorção como, taxas de reação, capacidade de sorção, coeficientes de difusão etc (NASCIMENTO et al., 2014).

Nesta pesquisa, a avaliação do melhor ajuste dos modelos aos dados experimentais foi utilizado o coeficiente de correlação de Pearson $\left(R^{2}\right)$ obtido a partir dos gráficos lineares (figuras 43 a 45). Este coeficiente de correlação é o mais utilizado e expressa covariância de duas variáveis pelo produto de seus desvios padrões.

Figura 43 - Curvas linearizadas do modelo de Langmuir (A) e Freundlich (B) da sorção do óleo diesel sobre a banana em sistema geral.

A - Langmuir

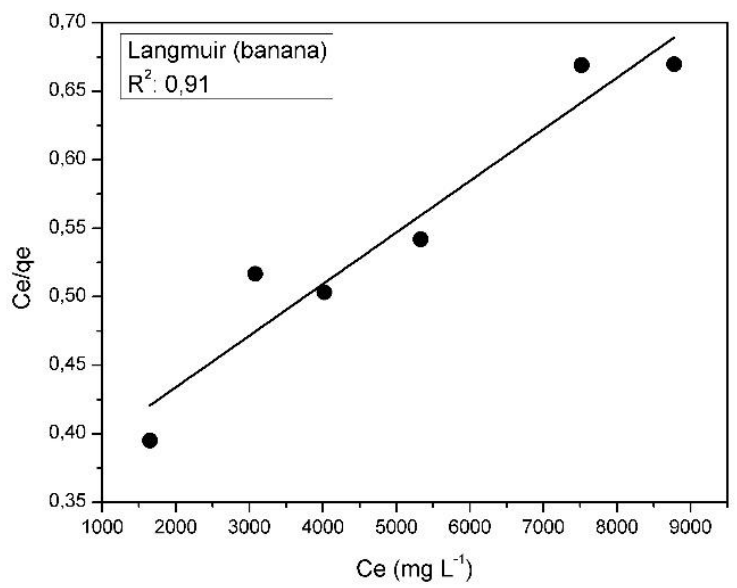

B - Freundlich

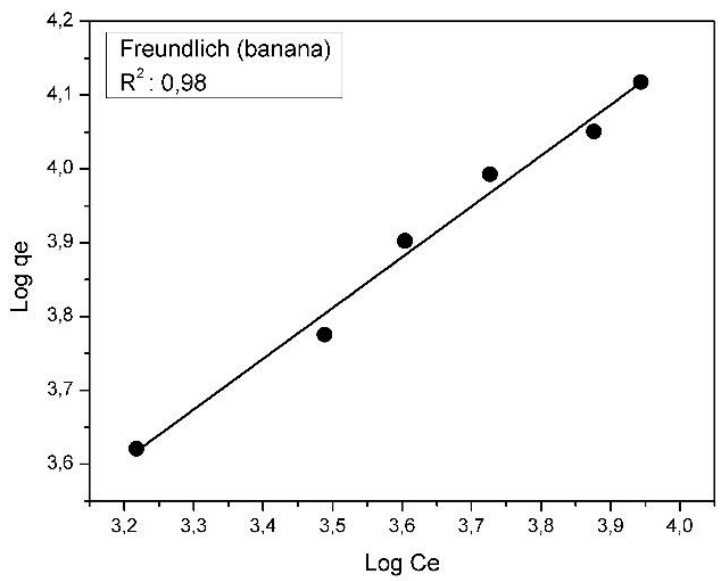

Fonte - autora da dissertação. 
Figura 44 - Curvas linearizadas do modelo de Langmuir (A) e Freundlich (B) da sorção do óleo diesel sobre o coco em sistema geral.

$$
\text { A - Langmuir }
$$

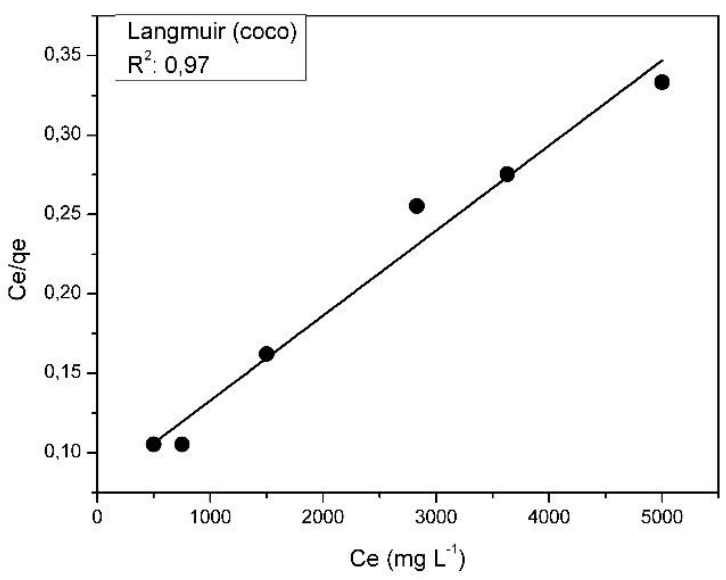

B - Freundlich

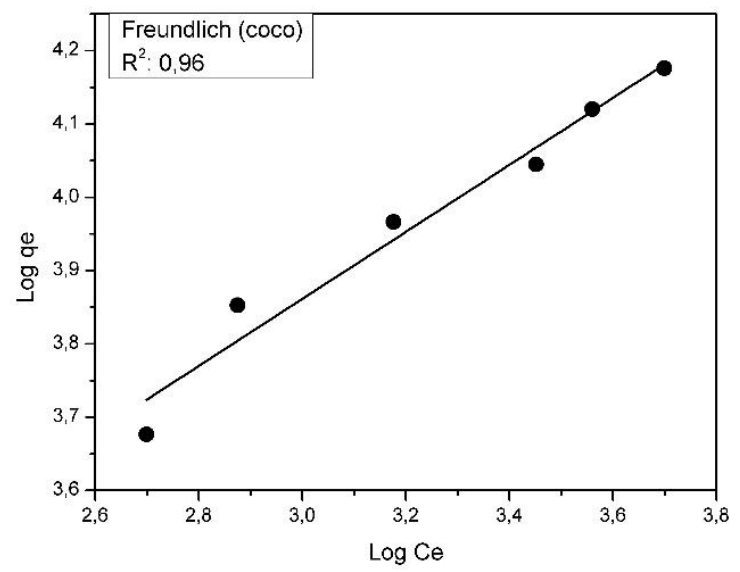

Fonte - autora da dissertação.

Figura 45 - Curvas linearizadas do modelo de Langmuir (A) e Freundlich (B) da sorção do óleo diesel sobre a laranja em sistema geral.

A - Langmuir

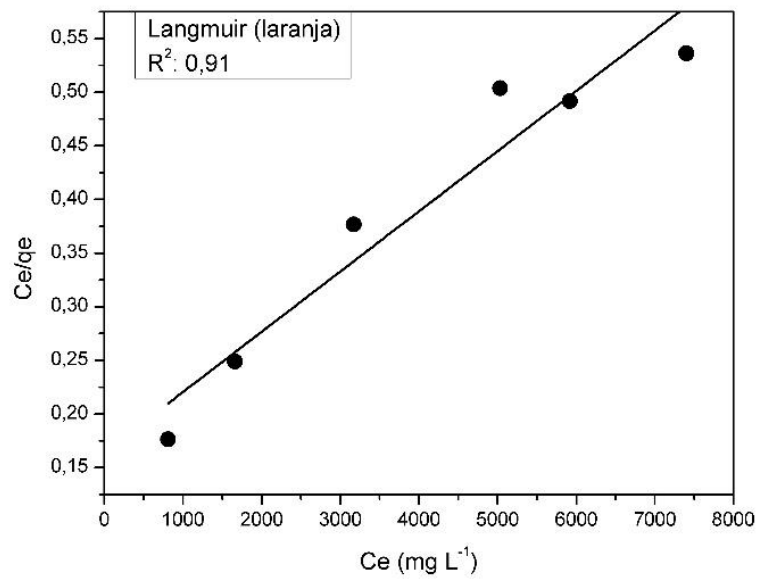

B - Freundlich

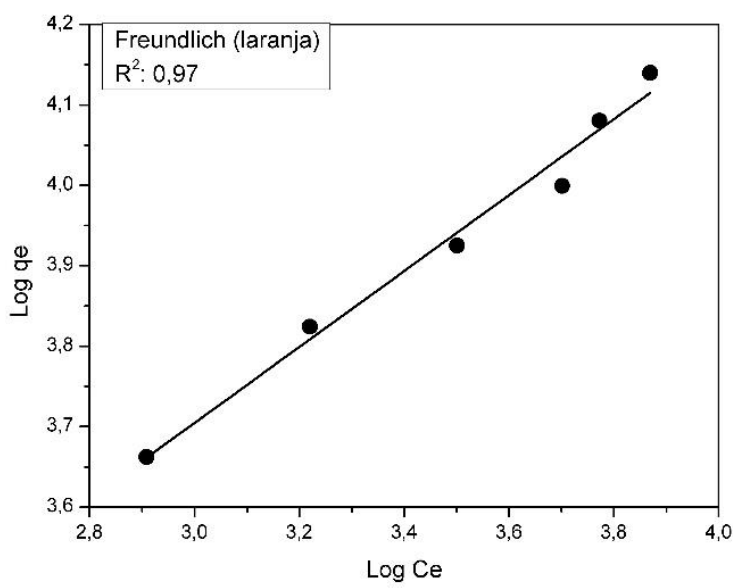

Fonte - autora da dissertação.

O valor de $R^{2}$ varia entre 0 e 1 e quanto mais próximo de 1 estiver, menor será o erro associado à modelação. Sendo que na faixa de 0,9 a 1 indica que as isotermas são adequadas para o sistema de sorção em que o valor próximo de 1 é altamente desejável (MAGDALENA, 2015; DIN e HAMMED, 2010). 
Assim, os três biossorventes analisados obtiveram coeficientes de Pearson acima de 0,9 sendo condizentes com uma boa modelagem. $O$ sistema que melhor se ajustou aos dados foi o de Freundlich, onde o $\mathrm{R}^{2}$ ficou acima de 0,95 (tabela 19).

\begin{tabular}{lccc}
\multicolumn{5}{c}{$\begin{array}{l}\text { Tabela 19 - Coeficiente de Pearson dos modelos de Langmuir e Freundlich da sorção do óleo } \\
\text { diesel sobre os biossorventes em sistema geral. }\end{array}$} & Banana & Coco & Laranja \\
\hline $\mathbf{R}^{\mathbf{2}}$ & 0,91 & 0,97 & 0,91 \\
\hline Langmuir & 0,98 & 0,96 & 0,97 \\
\hline Freundlich & &
\end{tabular}

Magdalena (2015), descreve que de um modo geral, as isotermas convexas são favoráveis e representam normalmente a sorção por sólidos microporosos. As formas mais complexas podem estar associadas com sorção multicamada e/ou com variações nos tamanhos dos poros do material sorvente.

Uma isoterma de sorção típica apresenta a relação de equilíbrio existente entre o sorvato na solução e retido no sorvente, a uma determinada temperatura. Essa relação é melhor visualizada traçando-se a curva qe versus $C_{e}$ (MAGDALENA, 2015; NASCIMENTO et al., 2014).

Pela forma da curva da isoterma, pode-se também determinar o mecanismo e indicar o tipo de sorção que ocorre entre o sorvente e o sorvato (GILES et. al., 1974). De acordo com essa classificação, os gráficos da figura 46, apresentaram curva do tipo $\mathrm{H}$ (high affinity), onde se encaixam como um caso especial de curva tipo L, o que indica alta afinidade do sorvente pelo soluto sorvido. 
Figura 46 - Isotermas de sorção óleo água sobre os biossorventes pelos modelos de Langmuir e Freundlich

A - Banana

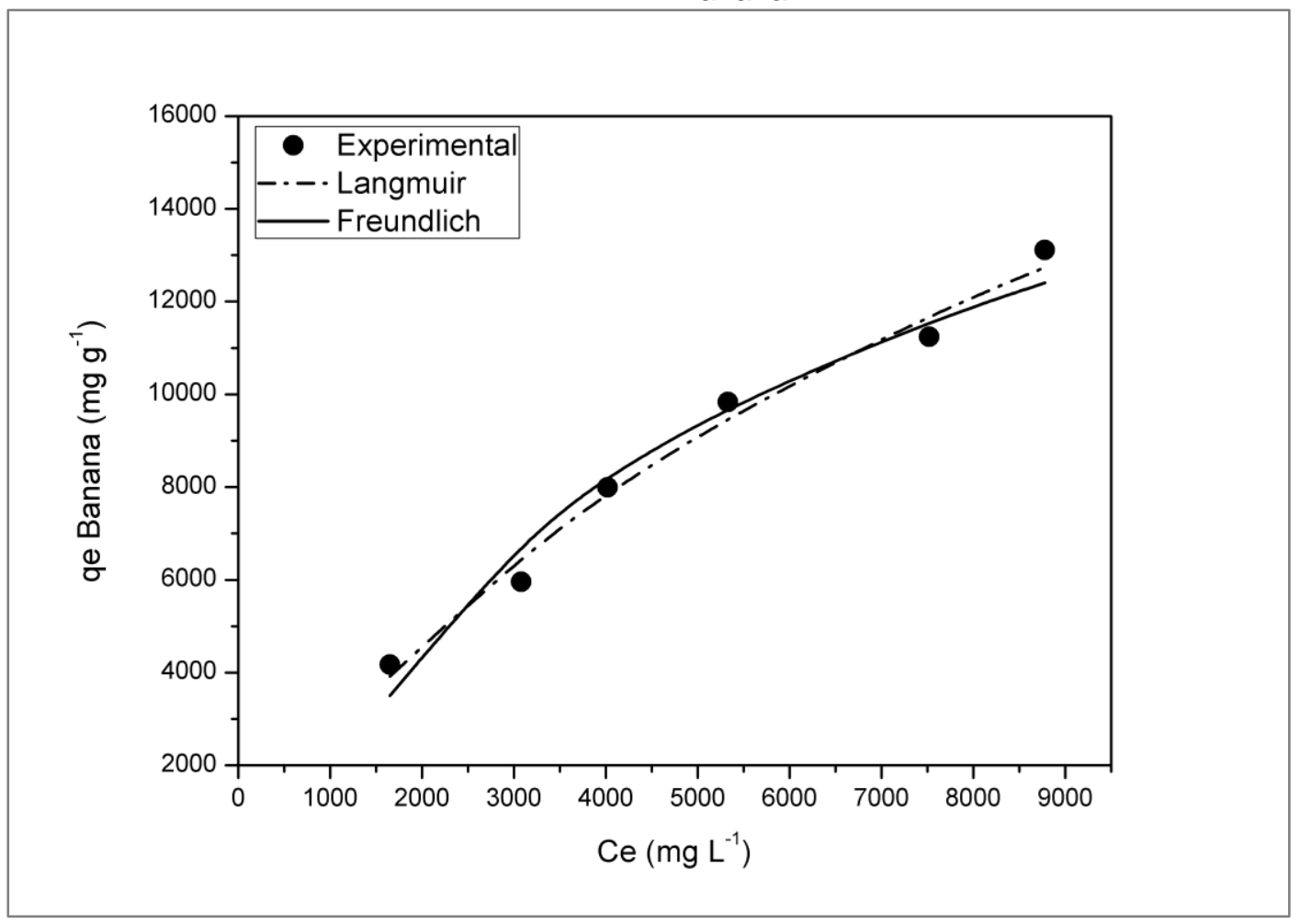

B - Coco

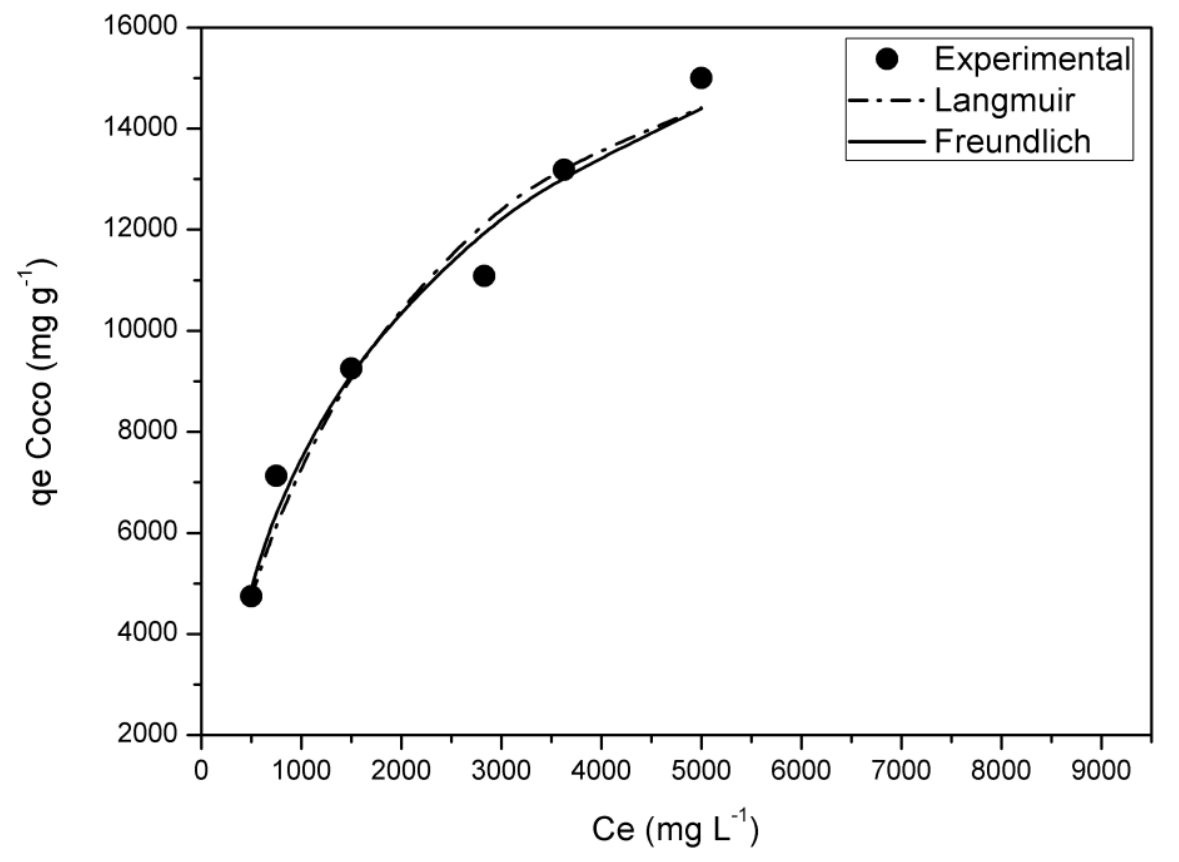


C - Laranja

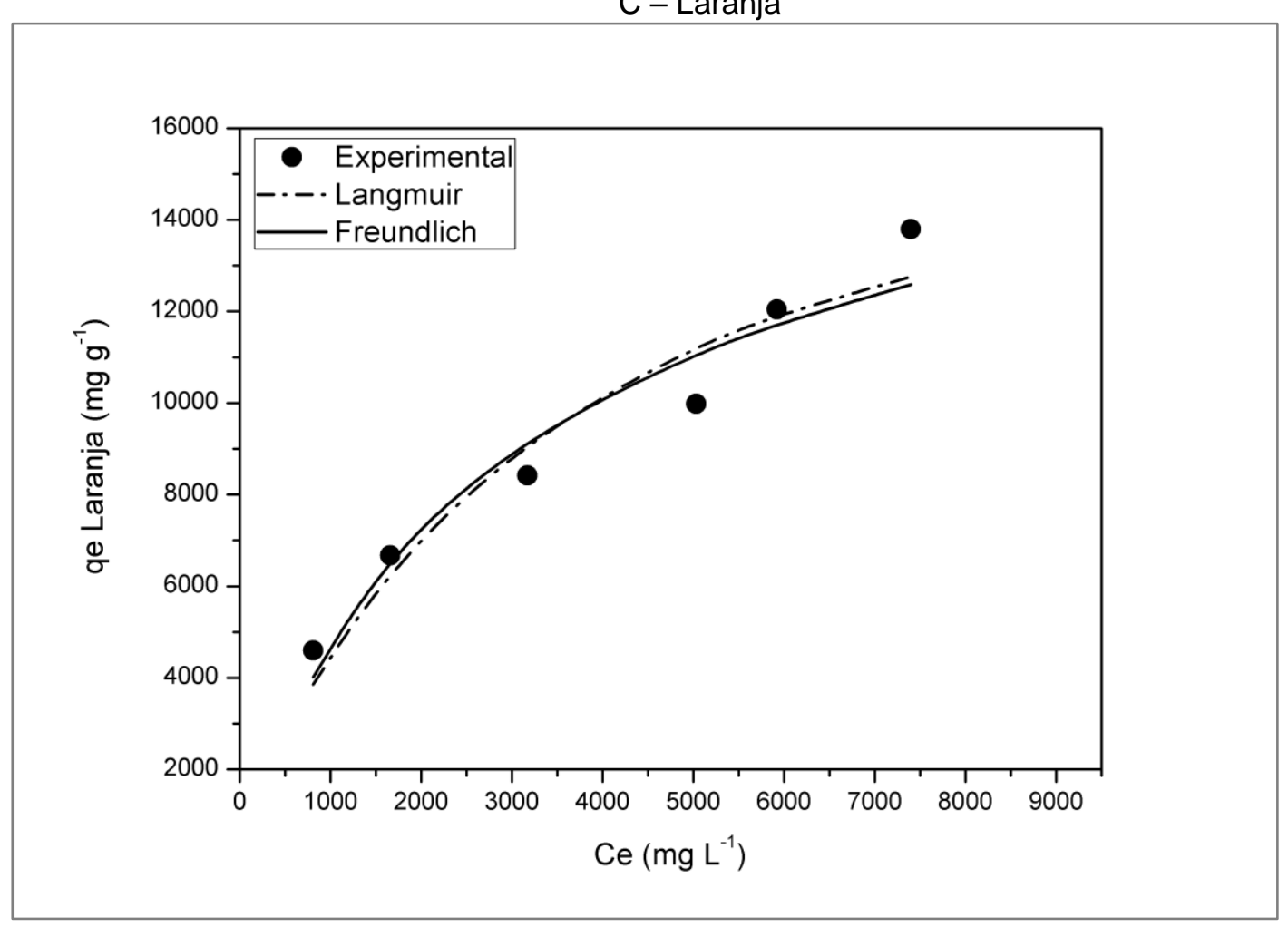

Fonte - autora da dissertação.

Os dados experimentais do modelo de Langmuir são apresentados na tabela 20, neste sistema foi analisado os resultados de $Q_{\max }$ e $K_{L}$, onde $Q_{\max }$ representa a concentração das espécies sorvidas sobre a superfície, ou seja, todos os sítios disponíveis foram preenchidos, uma cobertura completa é atingida.

Observa-se também, na tabela 20, que a capacidade máxima de sorção em sistema monoelementar usando 0 modelo linear seguiu a ordem banana>coco>laranja. Em geral, de acordo com Nascimento et al., (2014), sorventes eficientes apresentam altos valores de $Q_{\max }$ e KL. A constante $K_{L}$ está relacionada com a energia livre de sorção, que corresponde à afinidade entre a superfície do sorvente e o sorvato. 
Tabela 20 - Dados das equações de Langmuir da sorção do óleo diesel sobre os biossorventes em sistema geral.

\begin{tabular}{lccc}
\hline Langmuir & Banana & Coco & Laranja \\
\hline $\mathrm{Q}_{\max }\left(\mathrm{mg} \mathrm{g}^{-1}\right)$ & $26.547,66$ & $18.684,50$ & $17.814,74$ \\
\hline $\mathrm{K}_{\mathrm{L}}\left(\mathrm{L} \mathrm{mg}^{-1}\right)$ & $1,05 \times 10^{-4}$ & $6,74 \times 10^{-4}$ & $3,41 \times 10^{-4}$ \\
\hline $\mathrm{R}^{2}$ & 0,91 & 0,97 & 0,91
\end{tabular}

Fonte - autora da dissertação.

Os dados experimentais do modelo de Freundlich são apresentados na tabela 21 , analisando os pressupostos sugeridos pelo presente modelo e sua equação, é relevante comentar que o modelo de Freundlich não impõe qualquer exigência de que a cobertura deve se aproximar de um valor constante, correspondente à formação de uma monocamada completa, à medida que $\mathrm{C}_{e}$ aumenta.

Foi também mencionado na revisão de literatura, que a equação de Freundlich implica que a distribuição de energia para os sítios de adsorção é essencialmente do tipo exponencial, ao invés do tipo uniforme como considerada no desenvolvimento da equação de Langmuir.

De acordo com Cooney (1999), há evidências experimentais de que as distribuições de energia talvez não sejam estritamente do tipo exponencial. Assim, considera-se que alguns sítios são altamente energéticos e a ligação do soluto sorvido se dá fortemente, enquanto alguns são muito menos energéticos e, consequentemente, a ligação se dá mais fracamente.

Em geral, uma sorção favorável tende a ter um valor de $\mathrm{n}$ (constante de Freundlich) entre 1 e 10. Quanto maior o valor de $n$, mais forte a interação entre o sorvato e o sorvente (NASCIMENTO et al., 2014).

Tabela 21 - Dados das equações de Freundlich da sorção do óleo diesel sobre os biossorventes em sistema geral.

\begin{tabular}{lccc}
\hline Freundlich & Banana & Coco & Laranja \\
\hline $\mathrm{K}_{\mathrm{F}}\left(\mathrm{mg} \mathrm{g}^{-1}\right)\left(\mathrm{L} \mathrm{mg}^{-1}\right)^{\mathrm{n}}$ & 1,40 & 2,49 & 2,12 \\
\hline $\mathrm{N}$ & 1,45 & 2,19 & 2,29 \\
\hline $\mathrm{R}^{2}$ & 0,98 & 0,96 & 0,97
\end{tabular}

Fonte - autora da dissertação. 
Neste sistema em granulometria geral, a modelagem de isotermas que obteve melhor ajuste foi a de Freundlich. De acordo com o valor de $\mathrm{n}$ apresentado na tabela 21, o biossorvente que obteve melhor desempenho foi o da laranja com $n$ de 2,29, seguido do coco com 2,19 e da banana com 1,45.

\subsubsection{Sistema por granulometria}

A granulometria do sistema foi analisada em tamanhos de grãos de $<0,25 \mathrm{~mm}$, 0,25 $\mathrm{mm}$ e 0,50 $\mathrm{mm}$ respectivamente para os biossorventes banana, coco e laranja. As curvas linearizadas da banana são apresentadas nas figuras de 47 a 49.

Figura 47 - Curvas linearizadas do modelo de Langmuir (A) e Freundlich (B) da sorção do óleo diesel sobre a banana por granulometria.

A - Langmuir
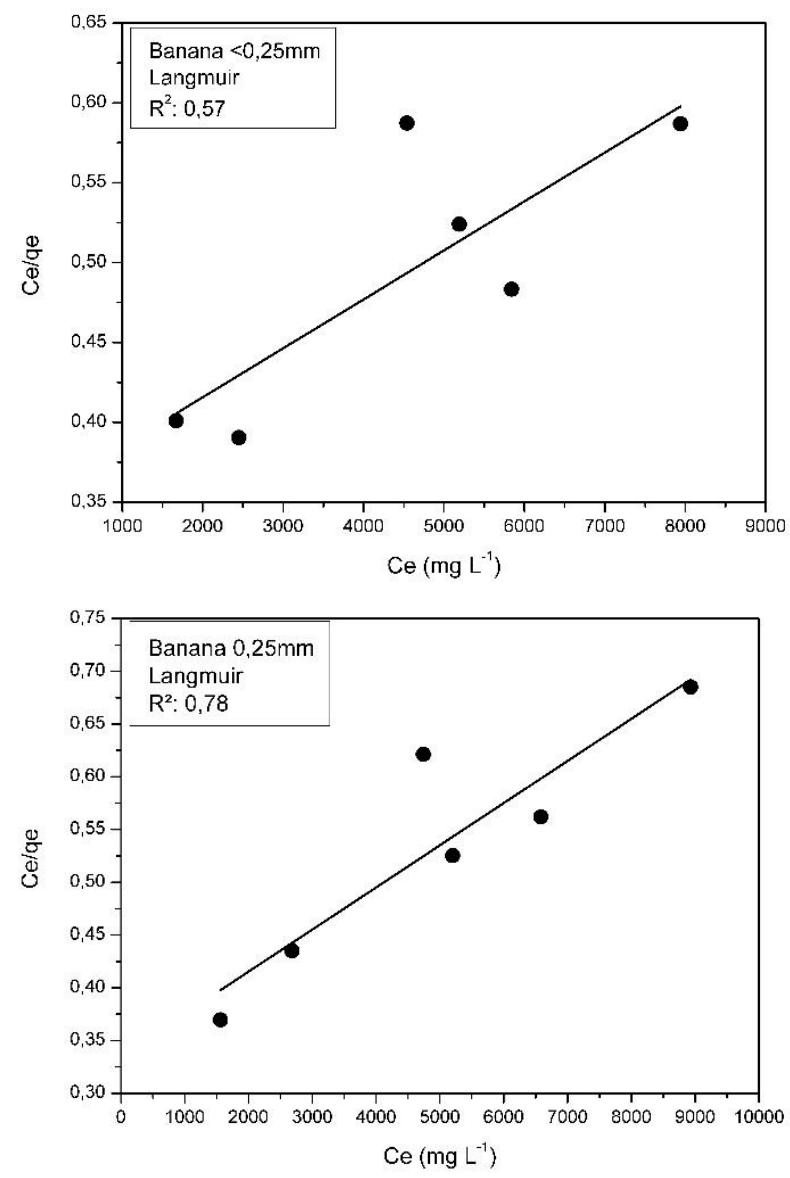

\section{B - Freundlich}
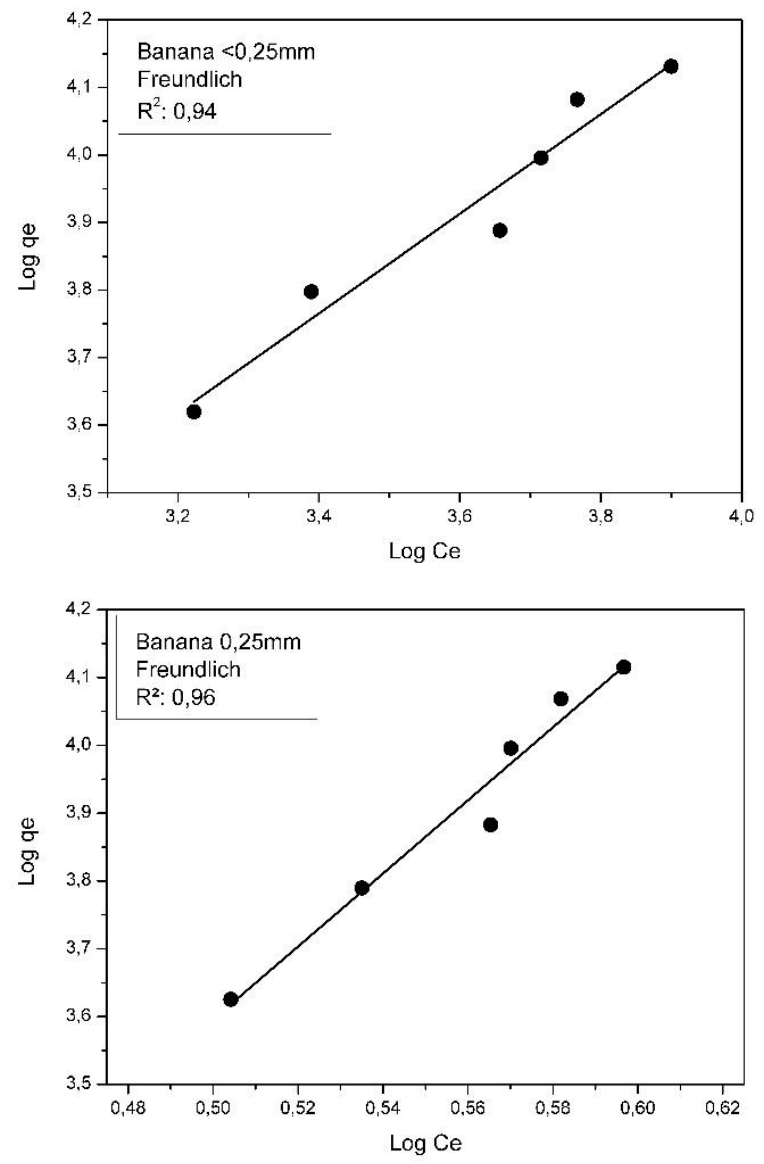

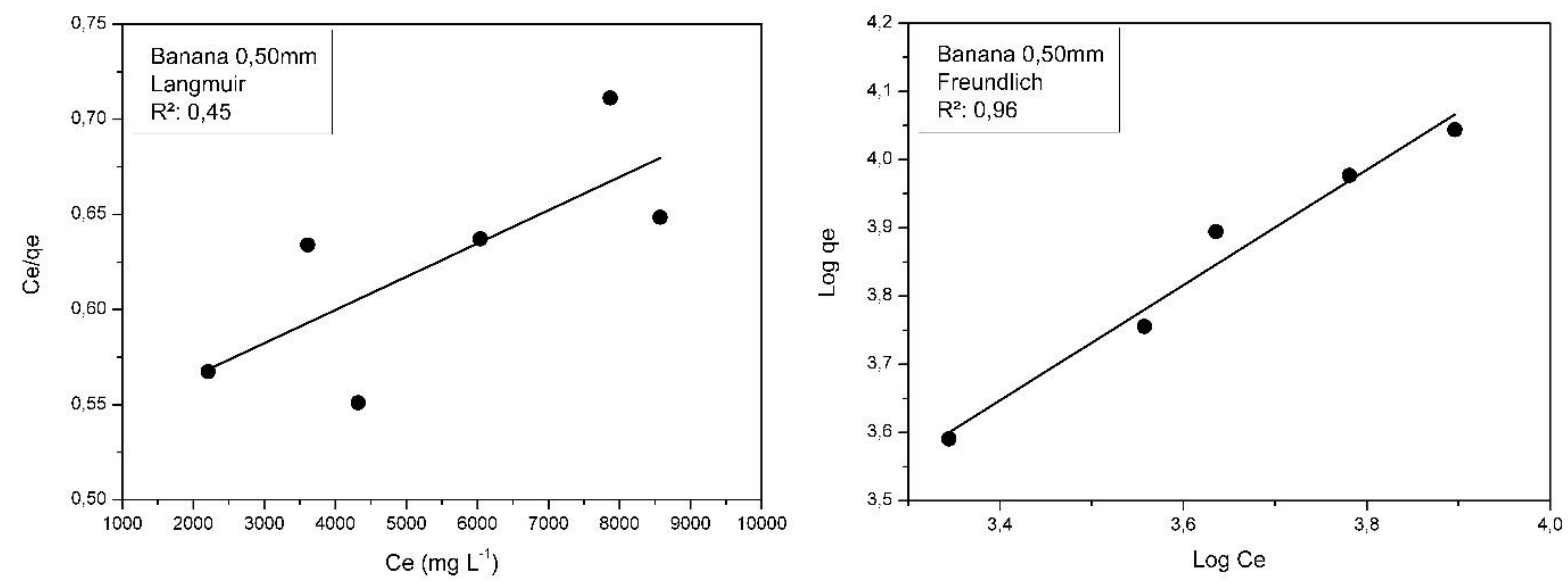

Fonte - autora da dissertação.

As curvas linearizadas do coco são apresentadas nos gráficos da figura 47.

Figura 48 - Curvas linearizadas do modelo de Langmuir (A) e Freundlich (B) da sorção do óleo diesel sobre o coco.

A - Langmuir
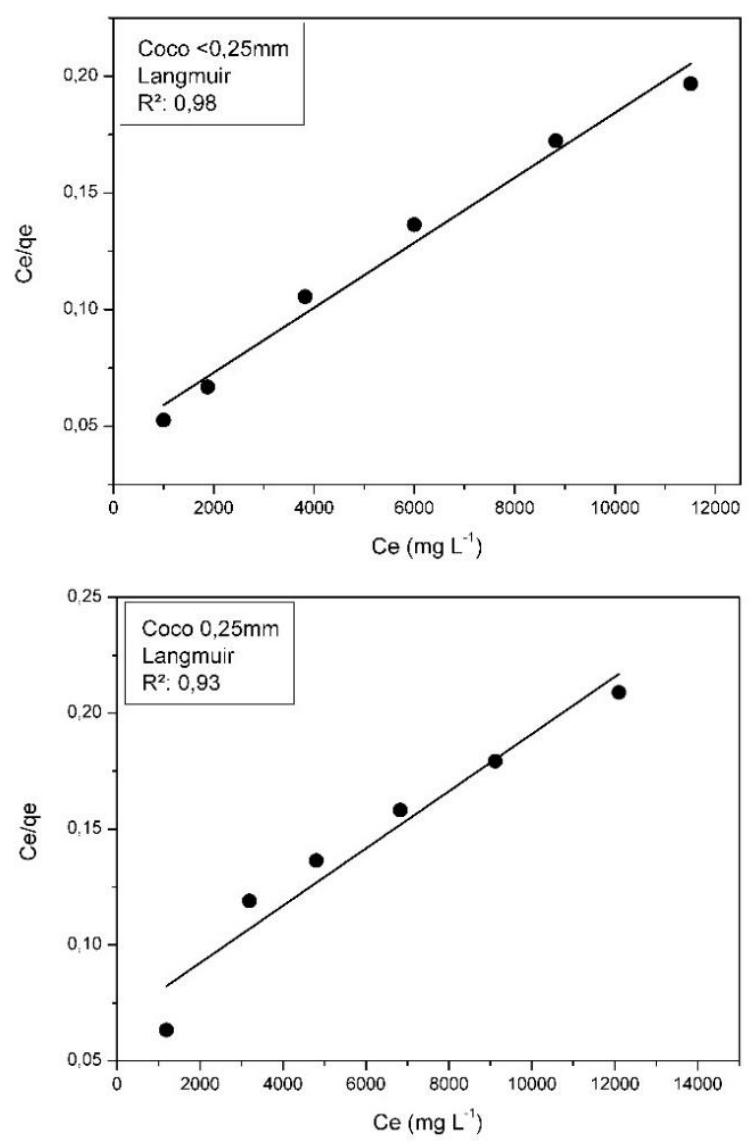

B - Freundlich
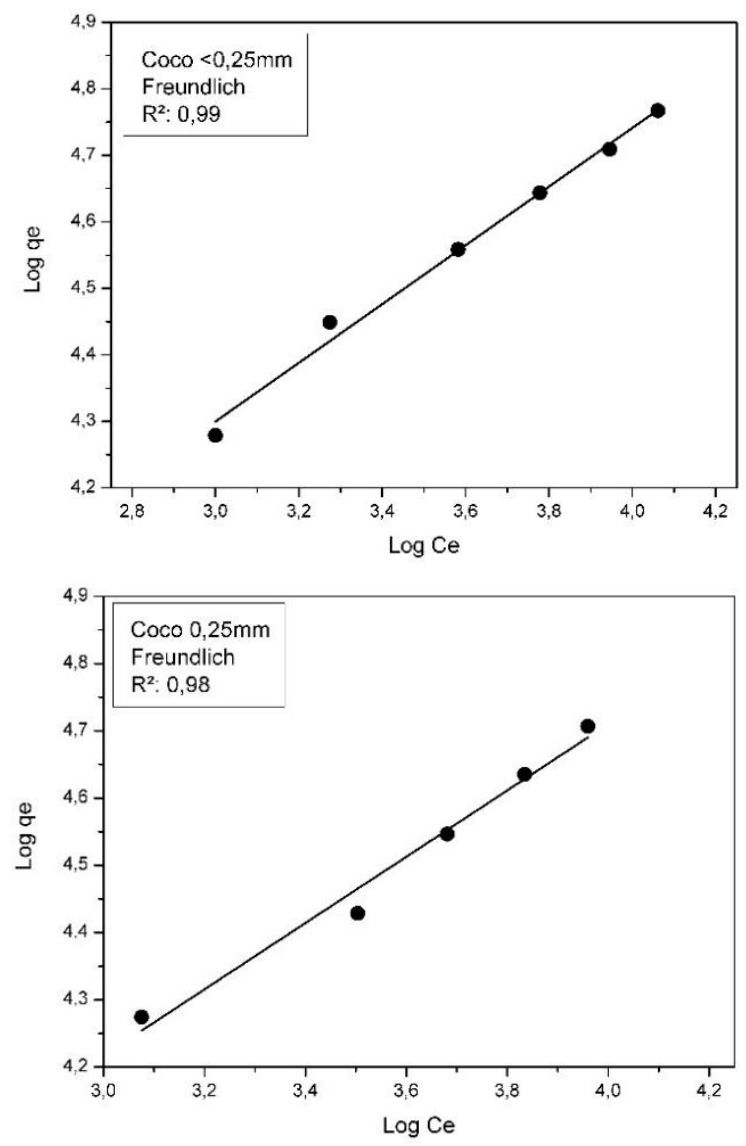

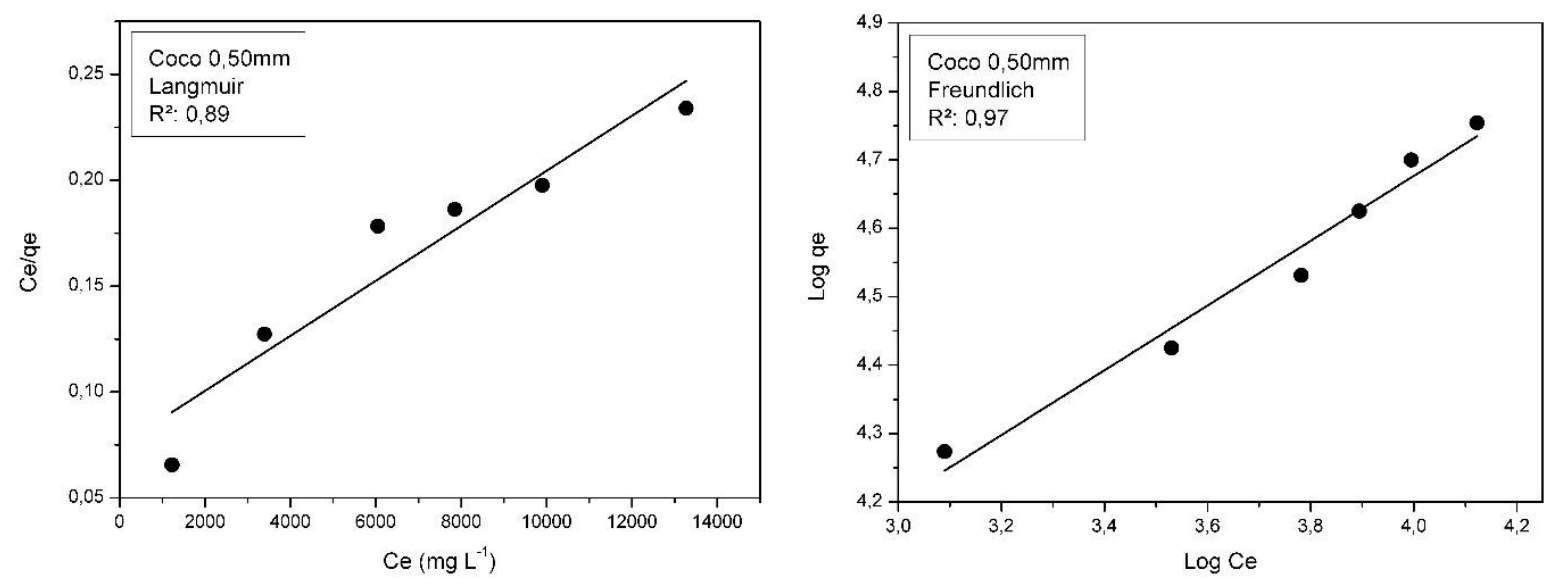

Fonte - autora da dissertação.

As curvas linearizadas da laranja são apresentadas nos gráficos da figura 48 .

Figura 49 - Curvas linearizadas do modelo de Langmuir (A) e Freundlich (B) da sorção do óleo diesel sobre a laranja.

A - Langmuir
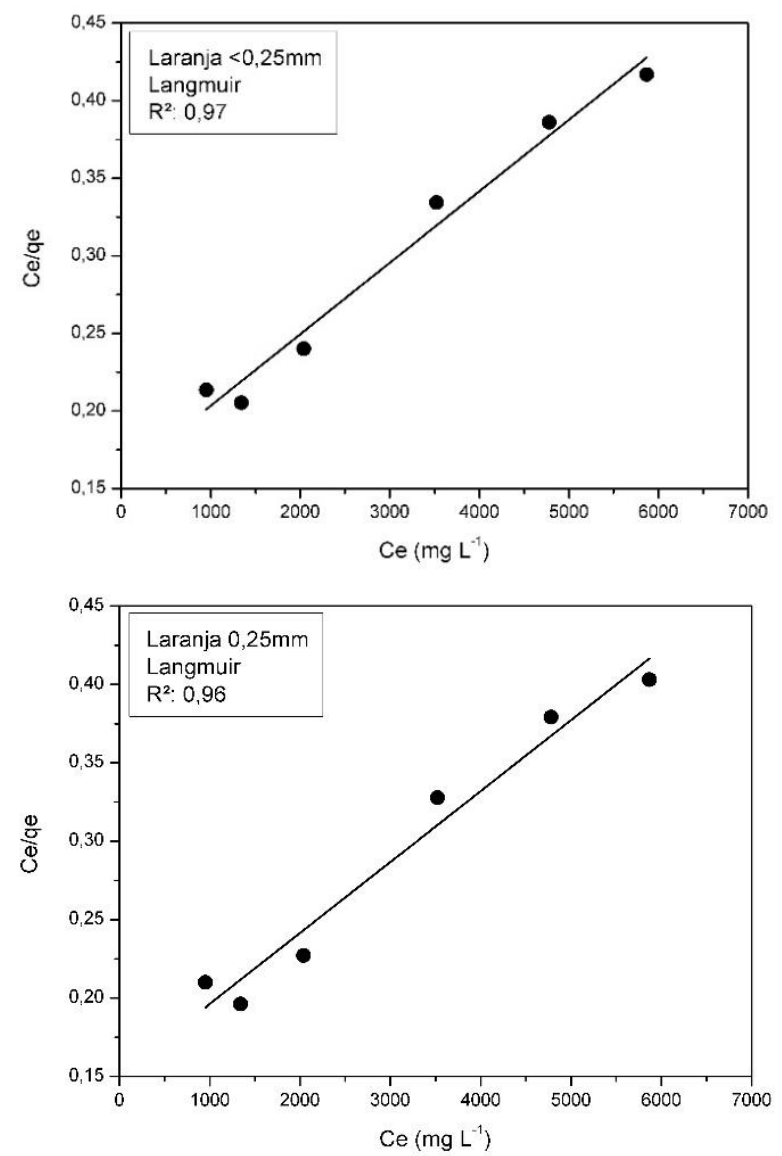

B - Freundlich
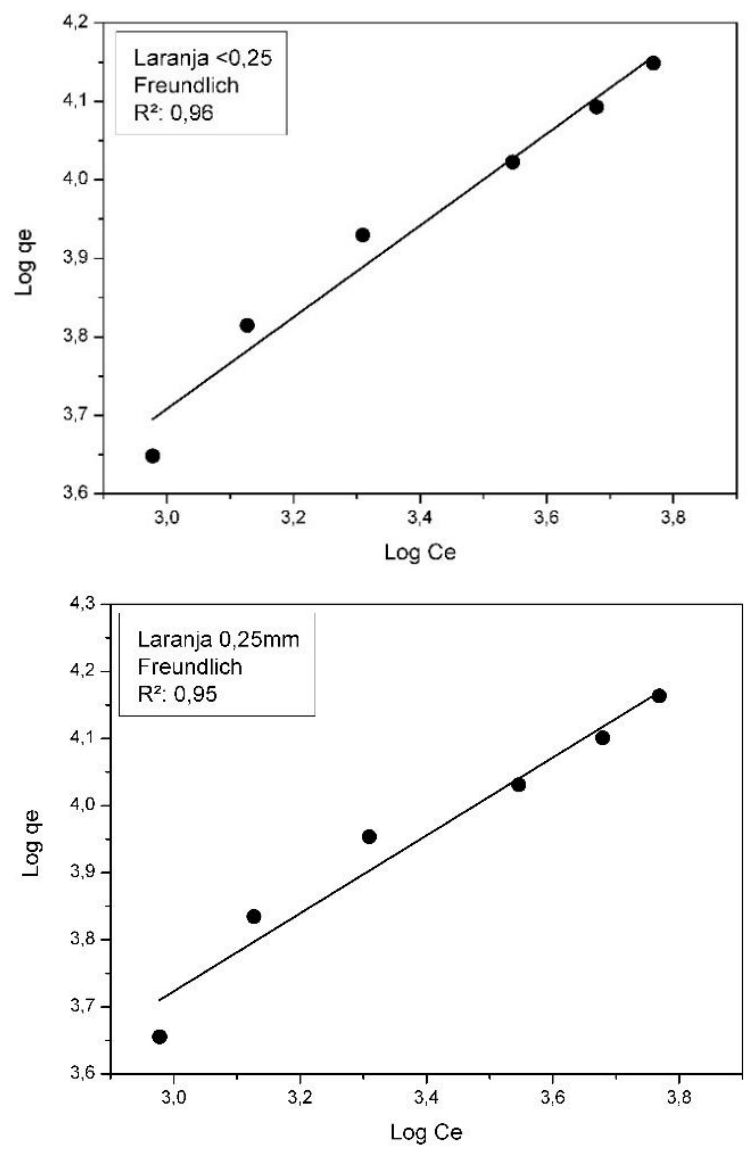

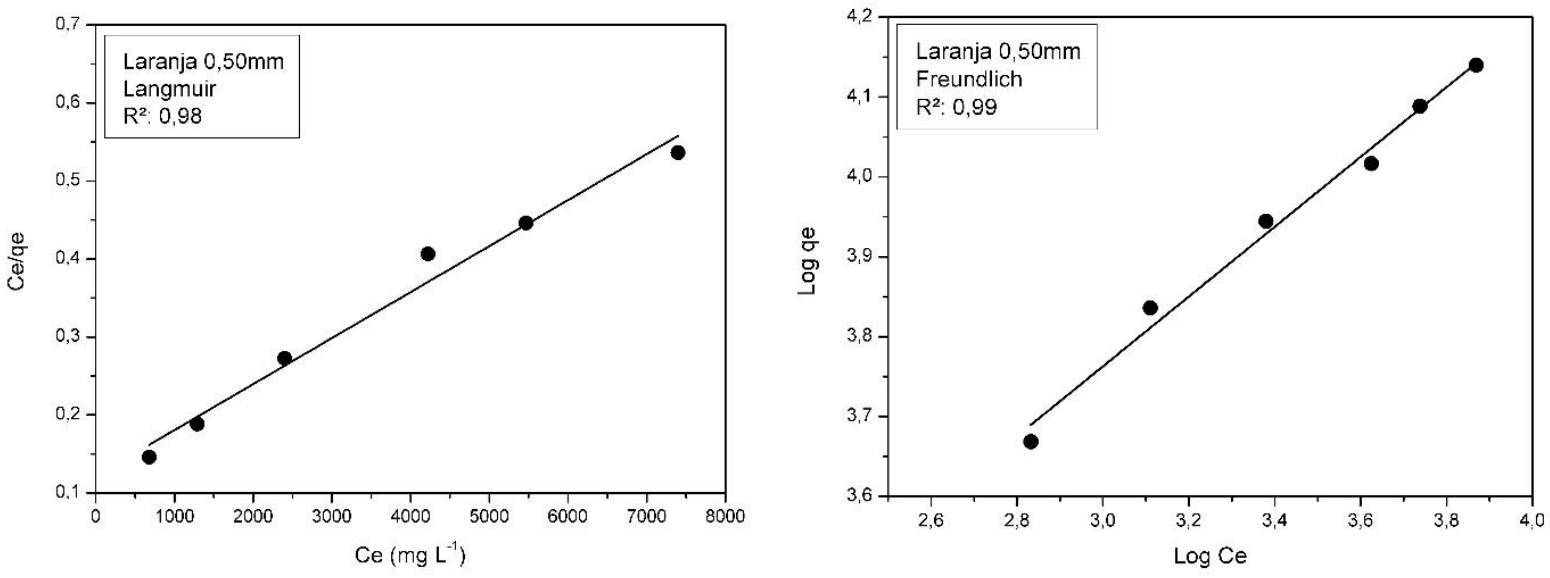

Fonte - autora da dissertação.

Para a banana, o melhor ajuste para o sistema de isotermas se deu no modelo de Freundlich, com $\mathrm{R}^{2}$ acima de 0,94, conforme tabela 22. Nesta mesma tabela é exibido os resultados das equações de Langmuir e Freundlich. Dentre as granulometrias analisadas, aquela que teve melhor eficiência foi em $0,25 \mathrm{~mm}$ com valos de $\mathrm{n}$ em Freundlich de 1,52.

Tabela 22 - Dados das equações de Langmuir e Freundlich dos biossorventes da banana por granulometria.

\begin{tabular}{|c|c|c|c|}
\hline Banana Langmuir & $<0,25 \mathrm{~mm}$ & $0,25 \mathrm{~mm}$ & $0,50 \mathrm{~mm}$ \\
\hline$Q_{\max }\left(\mathrm{mg} \mathrm{g}^{-1}\right)$ & $32.637,08$ & $25.000,00$ & $57.142,86$ \\
\hline $\mathrm{K}_{\mathrm{L}}\left(\mathrm{L} \mathrm{mg}^{-1}\right)$ & $8,65 \times 10^{-5}$ & $1,19 \times 10^{-4}$ & $3,30 \times 10^{-5}$ \\
\hline $\mathrm{R}^{2}$ & 0,57 & 0,78 & 0,45 \\
\hline \multicolumn{4}{|l|}{ Banana Freundlich } \\
\hline $\mathrm{K}_{\mathrm{F}}\left(\mathrm{mg} \mathrm{g}^{-1}\right)\left(\mathrm{L} \mathrm{mg}^{-1}\right)^{\mathrm{n}}$ & 1,26 & 1,52 & 0,77 \\
\hline $\mathrm{N}$ & 1,36 & 1,52 & 1,18 \\
\hline $\mathrm{R}^{2}$ & 0,94 & 0,96 & 0,96 \\
\hline
\end{tabular}

Fonte - autora da dissertação.

Para o coco, o melhor ajuste para o sistema de isotermas também se deu no modelo de Freundlich, com $\mathrm{R}^{2}$ acima de 0,98 , conforme tabela 23. Nesta mesma tabela é exibido os resultados das equações de Langmuir e Freundlich. Dentre as granulometrias analisadas, aquela que teve melhor eficiência foi em $<0,25 \mathrm{~mm}$ com valos de $\mathrm{n}$ em Freundlich de 2,26. 
Tabela 23 - Dados das equações de Langmuir e Freundlich dos biossorventes do coco por granulometria.

\begin{tabular}{|c|c|c|c|}
\hline Coco Langmuir & $<0,25 \mathrm{~mm}$ & $0,25 \mathrm{~mm}$ & $0,50 \mathrm{~mm}$ \\
\hline$Q_{\max }\left(\mathrm{mg} \mathrm{g}^{-1}\right)$ & $71.428,57$ & $81.009,70$ & $77.030,92$ \\
\hline $\mathrm{K}_{\mathrm{L}}\left(\mathrm{L} \mathrm{mg}^{-1}\right)$ & $3,10 \times 10^{-4}$ & $1,83 \times 10^{-4}$ & $1,74 \times 10^{-4}$ \\
\hline $\mathrm{R}^{2}$ & 0,98 & 0,93 & 0,89 \\
\hline \multicolumn{4}{|l|}{ Coco Freundlich } \\
\hline $\mathrm{K}_{\mathrm{F}}\left(\mathrm{mg} \mathrm{g}^{-1}\right)\left(\mathrm{L} \mathrm{mg}^{-1}\right)^{\mathrm{n}}$ & 0,05 & 2,74 & 2,78 \\
\hline $\mathrm{N}$ & 2,26 & 2,03 & 2,11 \\
\hline $\mathrm{R}^{2}$ & 0,99 & 0,98 & 0,97 \\
\hline
\end{tabular}

Fonte - autora da dissertação.

Para a laranja, numa visão geral, o melhor ajuste para o sistema de isotermas se deu no modelo de Freundlich, bem como os outros biossorventes analisados. $O$ valor de $R^{2}$ para a granulometria de $0,50 \mathrm{~mm}$ ficou em 0,99 conforme tabela 24 . Nesta mesma tabela é exibido os resultados das equações de Langmuir e Freundlich. Dentre as granulometrias analisadas, aquela que teve melhor eficiência foi em 0,50 mm com valos de $n$ em Freundlich de 2,45.

Tabela 24 - Dados das equações de Langmuir e Freundlich dos biossorventes da laranja por granulometria.

\begin{tabular}{lccc}
\hline Laranja Langmuir & $\mathbf{< , 2 5 m m}$ & $\mathbf{0 , 2 5} \mathbf{m m}$ & $\mathbf{0 , 5 0 m m}$ \\
\hline $\mathrm{Q}_{\max }\left(\mathrm{mg} \mathrm{g}^{-1}\right)$ & $21.691,97$ & $22.113,91$ & $16.959,15$ \\
\hline $\mathrm{K}_{\mathrm{L}}\left(\mathrm{L} \mathrm{mg}^{-1}\right)$ & $2,93 \times 10^{-4}$ & $2,99 \times 10^{-4}$ & $4,85 \times 10^{-4}$ \\
\hline $\mathrm{R}^{2}$ & 0,97 & 0,96 & 0,98
\end{tabular}

\section{Laranja Freundlich}

\begin{tabular}{llll}
\hline $\mathrm{K}_{\mathrm{F}}\left(\mathrm{mg} \mathrm{g}^{-1}\right)\left(\mathrm{L} \mathrm{mg}^{-1}\right)^{\mathrm{n}}$ & 1,96 & 1,98 & 2,45 \\
\hline $\mathrm{N}$ & 1,72 & 1,70 & 2,45 \\
\hline $\mathrm{R}^{2}$ & 0,96 & 0,95 & 0,99 \\
\hline
\end{tabular}

Fonte - autora da dissertação.

Dentre os três biossorventes analisados, prevaleceu a modelagem de Freundlich com melhores ajustes de $\mathrm{R}^{2}$. Em relação a eficiência do sistema predominaram as sequências conforme a tabela 25. 
Tabela 25 - Sequência de eficiência dos biossorventes conforme constante $\mathrm{n}$ de Freundlich. Granulometria Constante $\mathrm{n}$ de Freundlich

$<0,25 \mathrm{~mm}$ coco $>$ laranja > banana

$0,25 \mathrm{~mm}$ coco $>$ laranja > banana

$0,50 \mathrm{~mm}$ laranja > coco > banana

Fonte - Autora da dissertação.

As figuras de 50 a 52 demostram as curvas qe versus $C_{e}$ para as três granulometrias dos biossorventes analisados. Sendo a figura 49 da banana, a 50 do coco e a 51 da laranja. São demostradas curvas convexas típicas de boa afinidade entre sorvente e soluto.

Figura 50 - Isotermas de sorção óleo/água sobre os biossorventes da banana por granulometria pelos modelos de Langmuir e Freundlich.

A - $<0,25 \mathrm{~mm}$

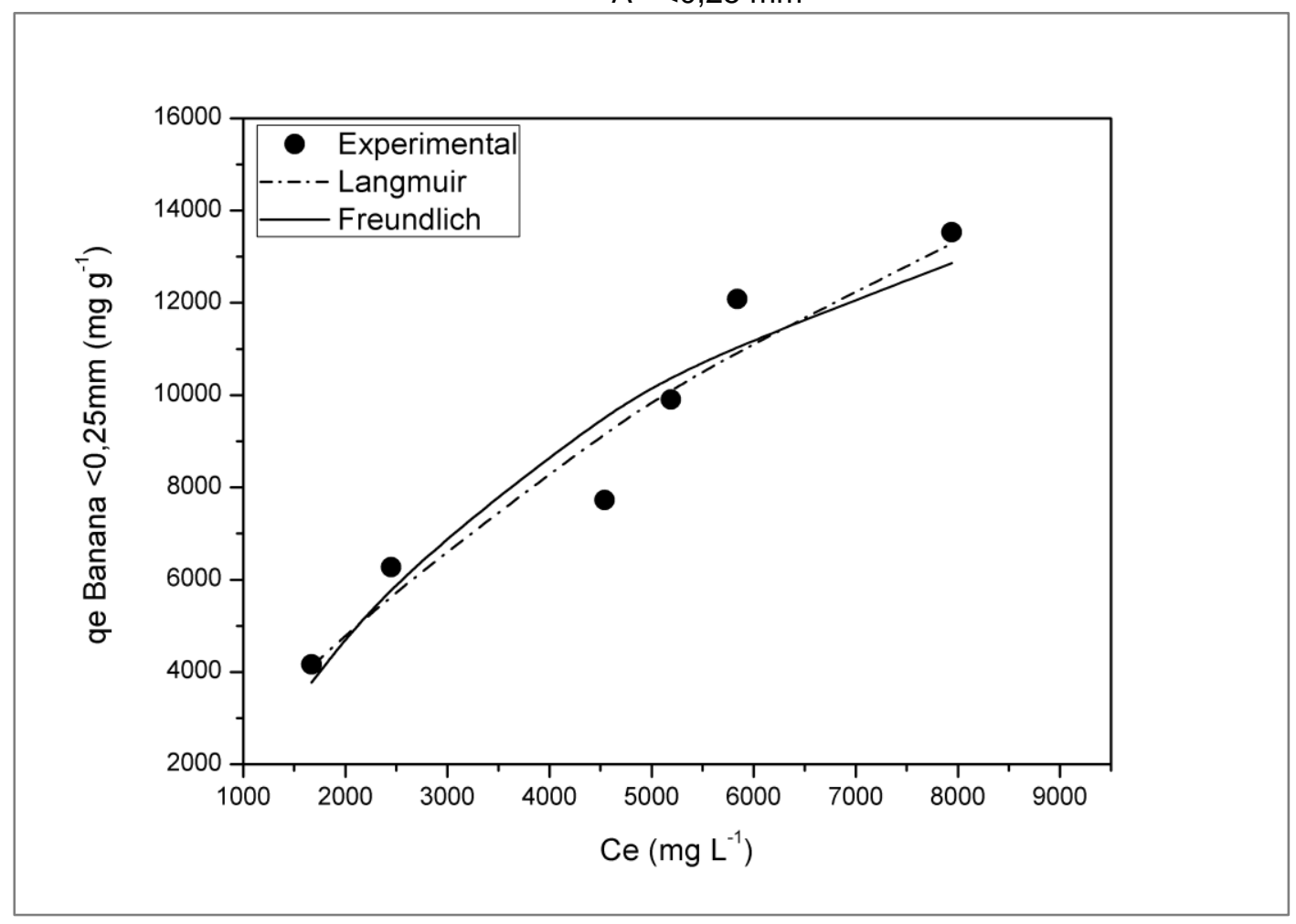



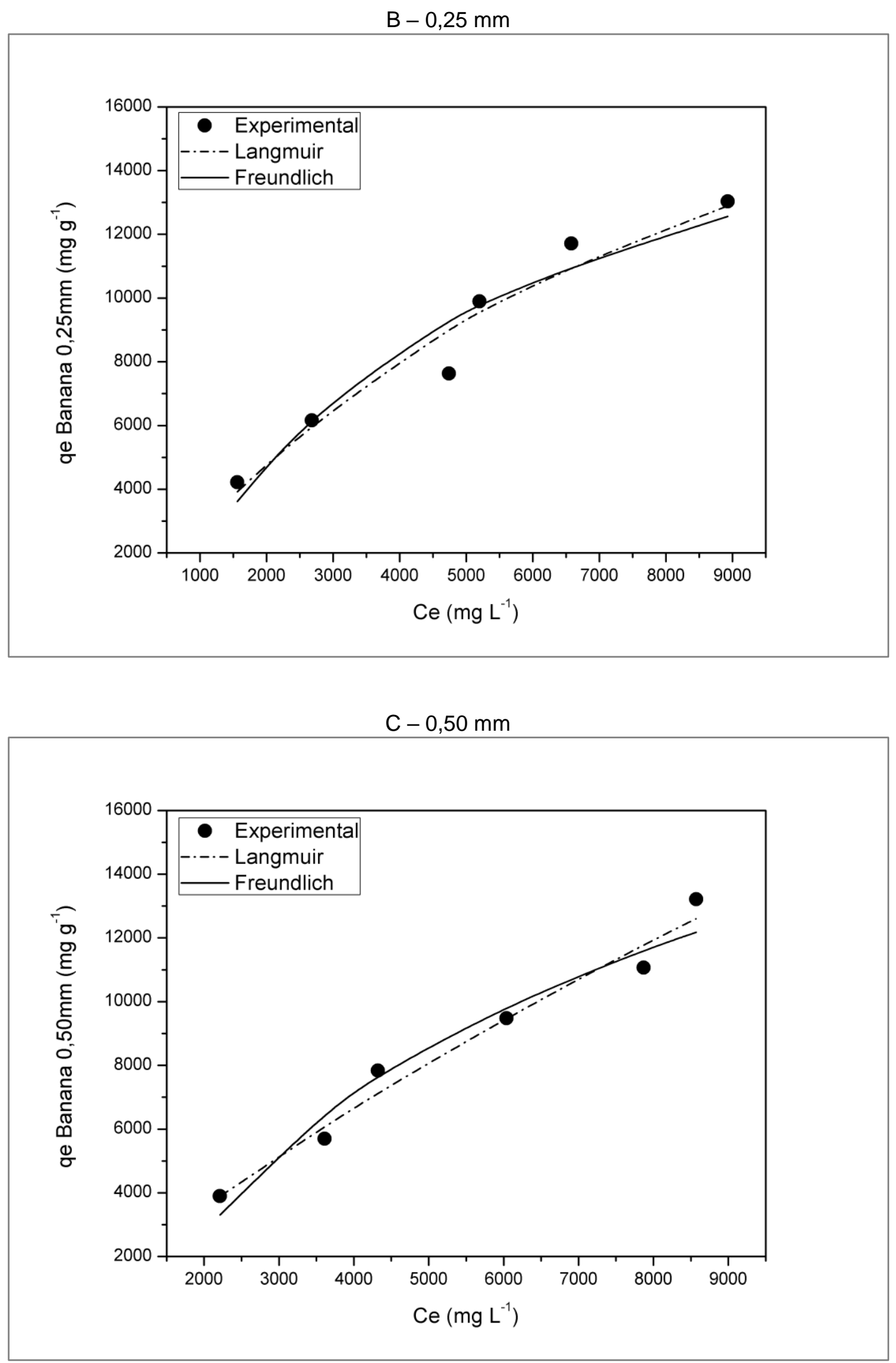

Fonte - autora da dissertação. 
Figura 51 - Isotermas de sorção óleo/água sobre os biossorventes do coco por granulometria pelos modelos de Langmuir e Freundlich.

A - <0,25 mm

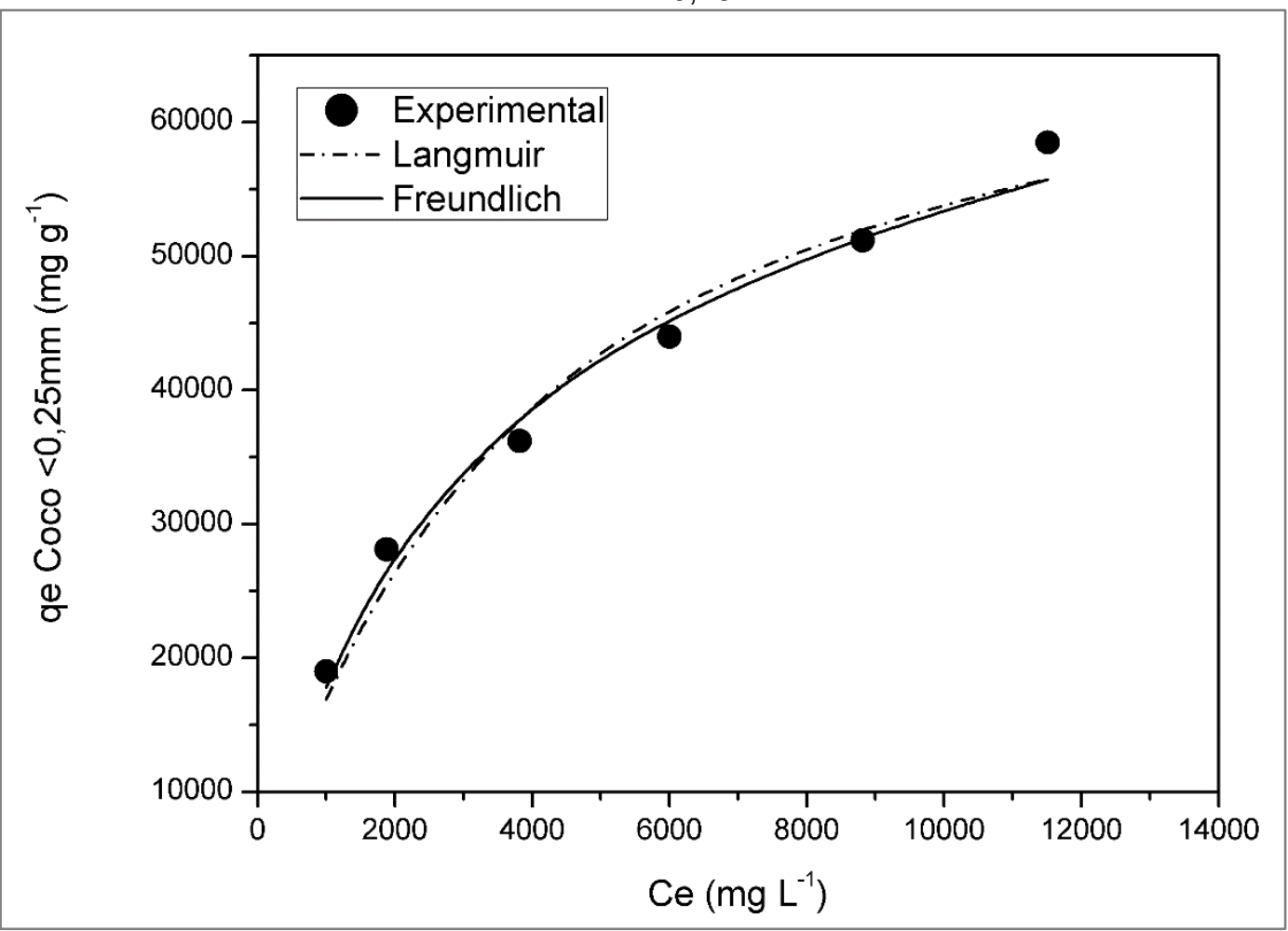

$B-0,25 \mathrm{~mm}$

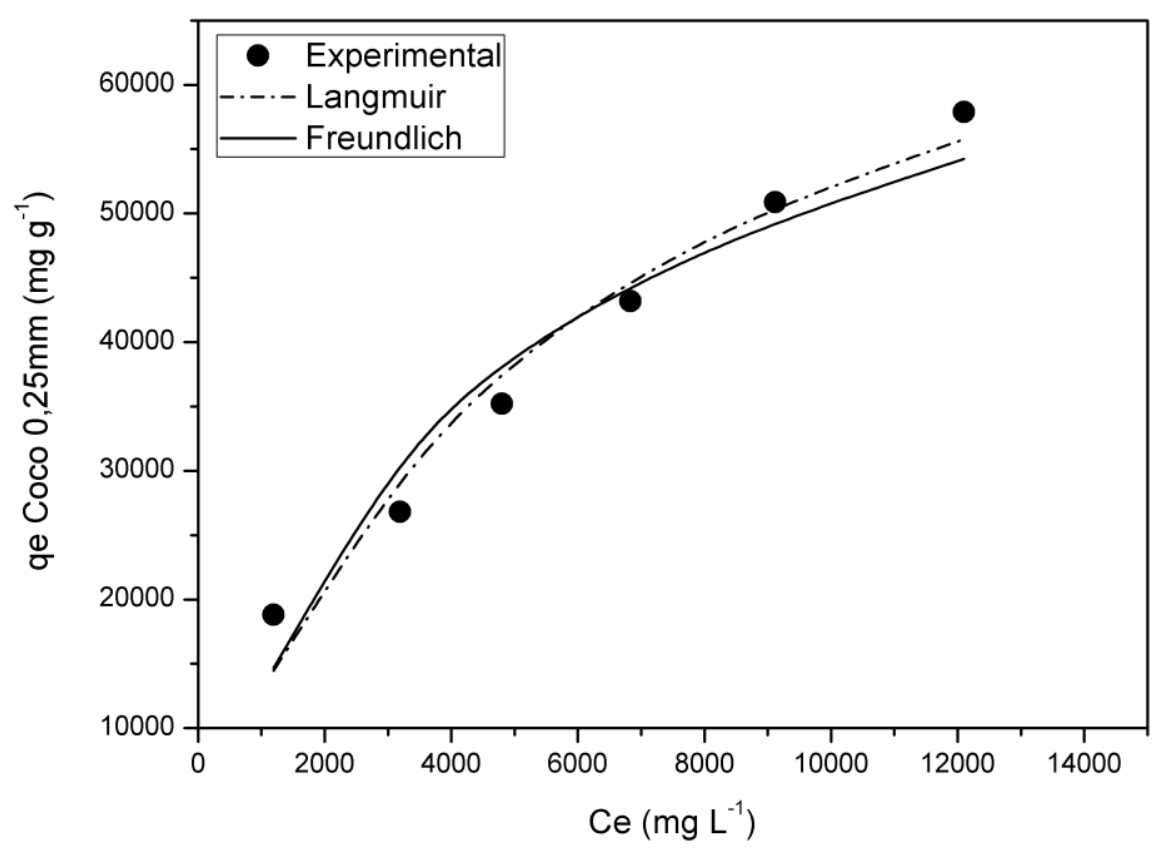




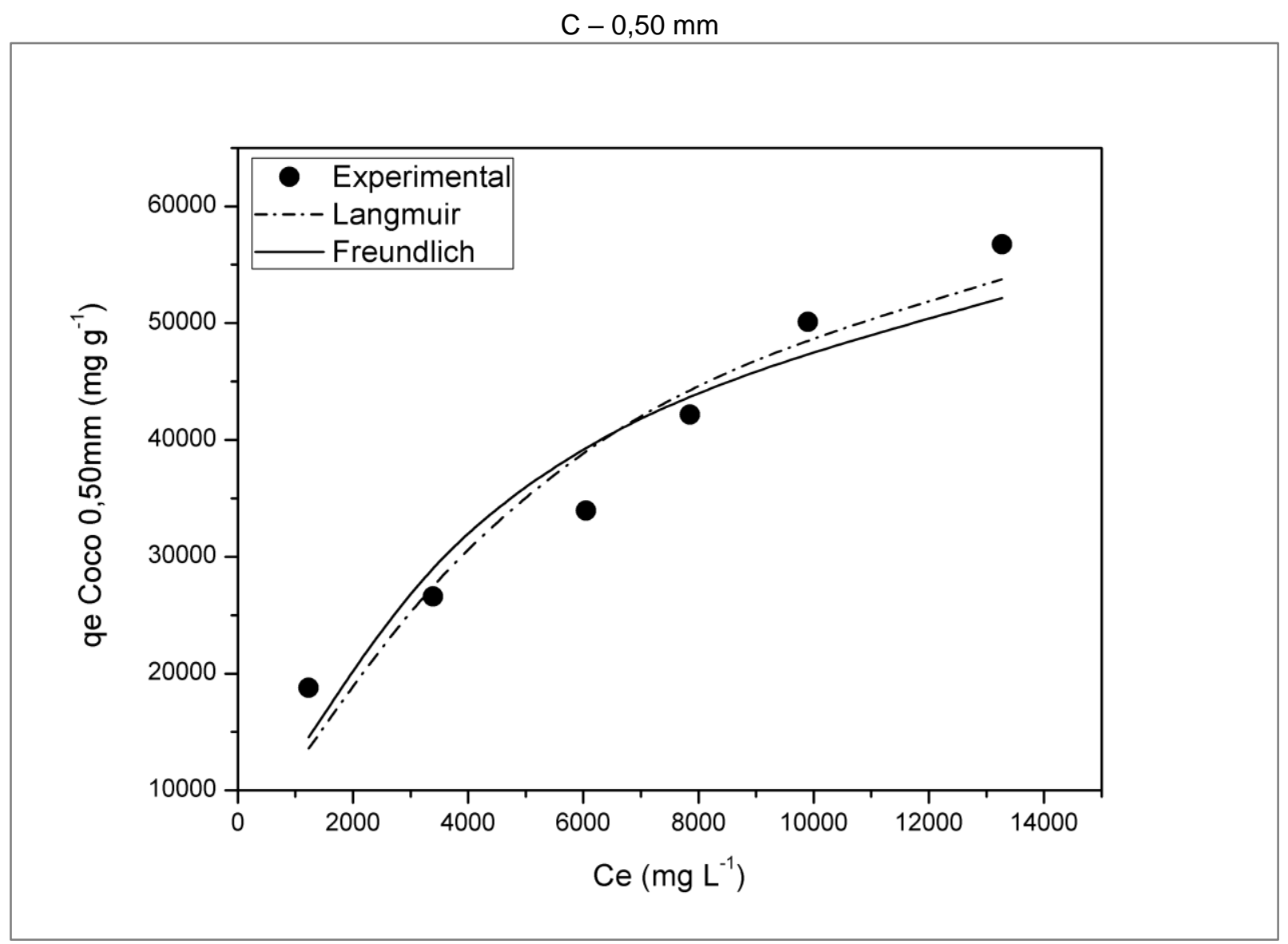

Fonte - autora da dissertação. 
Figura 52 - Isotermas de sorção óleo/água sobre os biossorventes da laranja por granulometria pelos modelos de Langmuir e Freundlich.

A $-<0,25 \mathrm{~mm}$

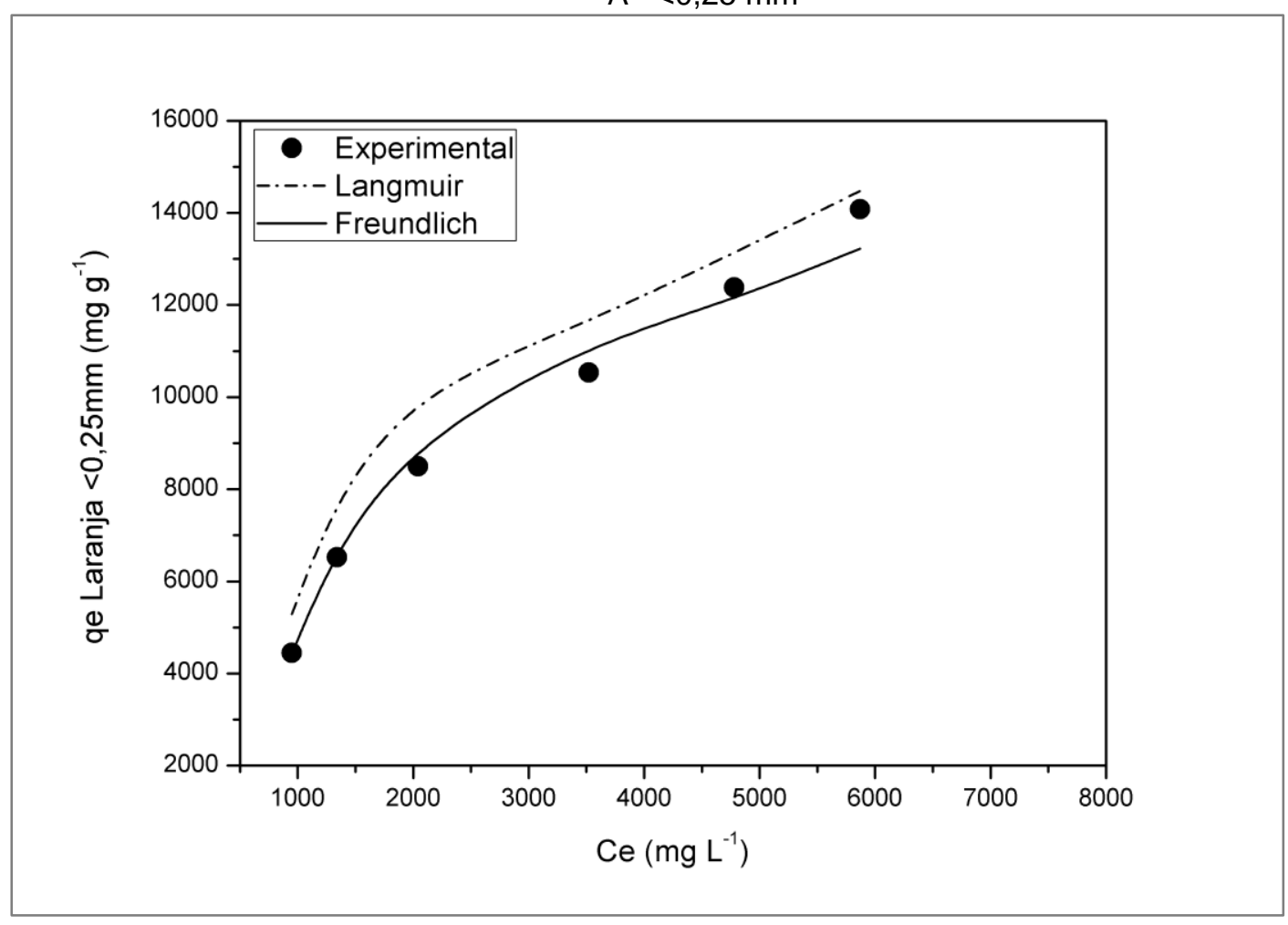

$B-0,25 \mathrm{~mm}$

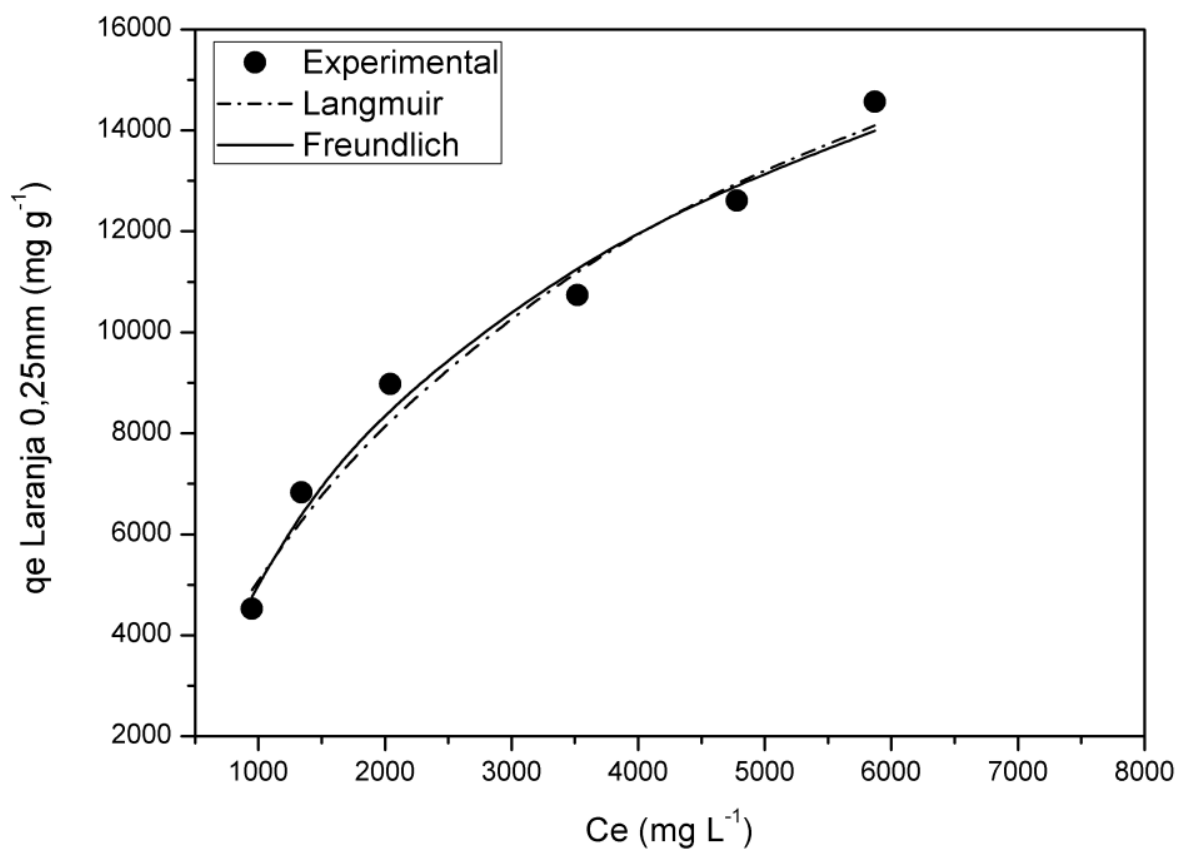




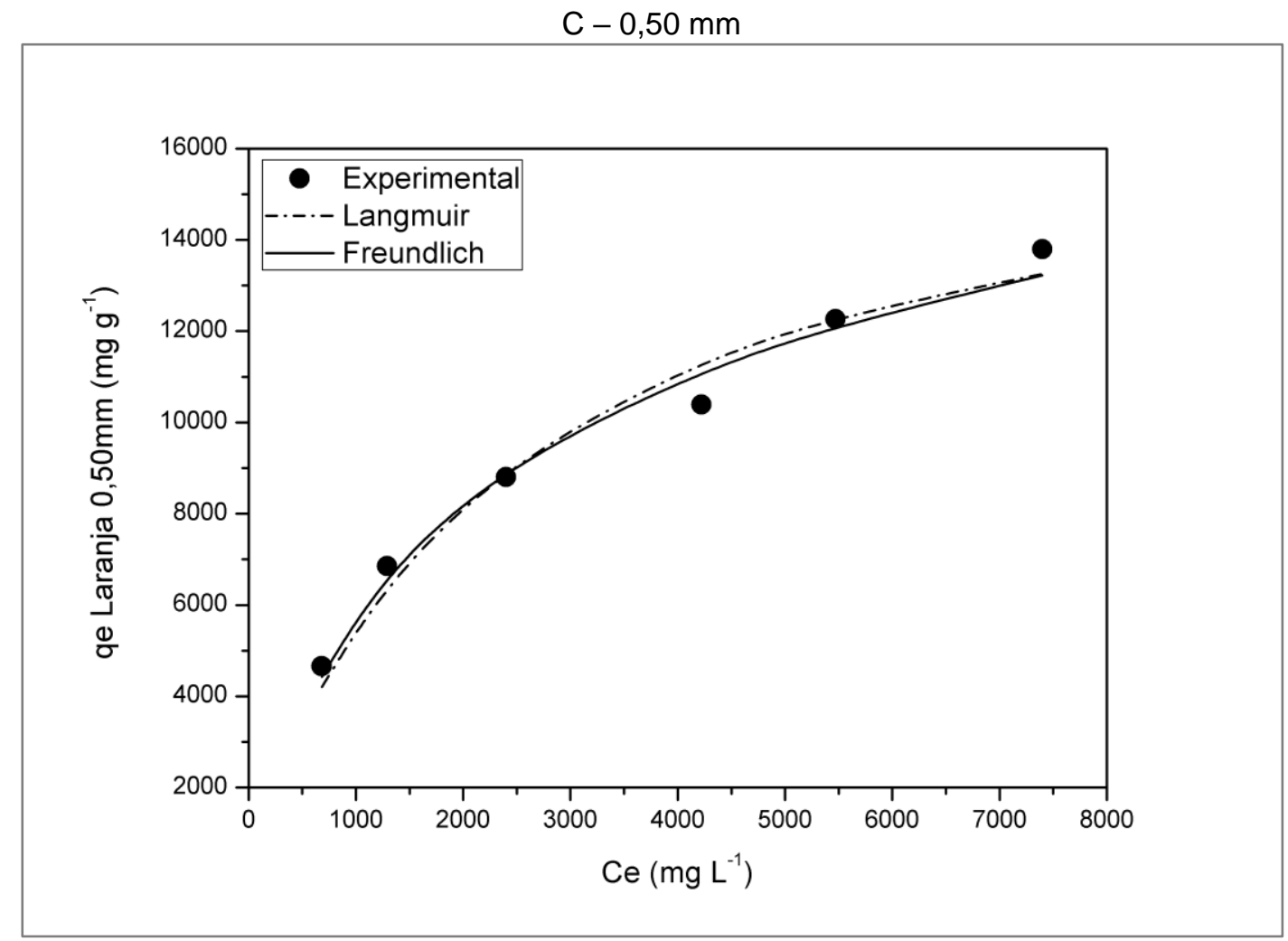

Fonte - autora da dissertação. 
Os três biossorventes foram eficientes, sendo considerados os melhores o coco na granulometria de $<0,25 \mathrm{~mm}$ e a laranja em $0,50 \mathrm{~mm}$. A tabela 26 exibe a relação da comparação entre o sistema geral e por granulometria de acordo com a constante n de Freundlich. Houve um aumento médio de 5\% na sorção.

Tabela 26 - Comparação entre o sistema geral e por granulometria de acordo com a constante $\mathrm{n}$ de Freundlich.

\begin{tabular}{|c|c|c|c|}
\hline 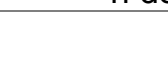 & Geral (n) & Granulometria (n) & Aumento (\%) \\
\hline \multicolumn{4}{|l|}{ Banana } \\
\hline$<0,25 \mathrm{~mm}$ & \multirow{3}{*}{1,45} & 1,36 & - \\
\hline $0,25 \mathrm{~mm}$ & & 1,52 & 4,83 \\
\hline $0,50 \mathrm{~mm}$ & & 1,18 & - \\
\hline \multicolumn{4}{|l|}{ Coco } \\
\hline$<0,25 \mathrm{~mm}$ & \multirow{3}{*}{2,19} & 2,26 & 3,20 \\
\hline $0,25 \mathrm{~mm}$ & & 2,03 & - \\
\hline $0,50 \mathrm{~mm}$ & & 1,70 & - \\
\hline \multicolumn{4}{|l|}{ Laranja } \\
\hline$<0,25 \mathrm{~mm}$ & \multirow{3}{*}{2,29} & 1,72 & - \\
\hline $0,25 \mathrm{~mm}$ & & 1,70 & - \\
\hline $0,50 \mathrm{~mm}$ & & 2,45 & 7,00 \\
\hline
\end{tabular}

Fonte - Autora da dissertação. 


\section{CONCLUSÕES}

Os ensaios de caracterização das fibras vegetais estudadas demonstraram propriedades típicas para vegetais: temperatura de termo oxidação em torno de $200^{\circ} \mathrm{C}$, concentrações de carbono em $\sim 45 \%$, densidade em $\sim 1,5 \mathrm{~g} / \mathrm{cm}^{3}$ e elementos inorgânicos presentes nas amostras como cálcio, potássio, sódio e silício.

Por meio das microscopias observou-se as características morfológicas dos materiais e o aumento da quantidade de poros, após a ativação por modificação química. O coco apresentou melhor resultado em flutuabilidade, com até 99,9\% em sistema dinâmico e hidrofobicidade com $36,6 \%$ de capacidade para repelir a água.

Nos ensaios de sorção de contaminantes em sistema seco geral, os três biossorventes analisados obtiveram resultados positivos, sendo eficientes. A laranja desempenhou melhor sorção, com até 1,45 gadsorvato/gbiossorvente em óleo diesel e 1,26 gadsorvato/gbiossorvente em gasolina, seguido da banana e do coco. Em média, para o óleo diesel, ela sorveu cerca de $40,78 \%$ a mais do que a banana e $57,61 \%$ a mais do que o coco. Para a gasolina, a laranja sorveu cerca de $106,56 \%$ a mais do que a banana e $200,00 \%$ a mais do que o coco.

Para este mesmo sistema, quando examinada a sorção por classificação granulométrica, os resultados demonstraram que as granulometrias menores foram mais eficientes tanto em óleo diesel, quanto em gasolina. O coco sorveu em média, 3,94 g/g de óleo diesel e 2,80 g/g de gasolina, passou assim, a ser o biossorvente mais eficiente, com aumento da sorção em mais de 300\% para óleo diesel e 500\% para gasolina, na granulometria de $0,25 \mathrm{~mm}$. Na sequência, a eficiência prosseguiu com a laranja e a banana, quando comparado aos biossorventes sem classificação granulométrica.

Nos ensaios de sorção dos contaminantes em sistema aquoso geral, o coco e a laranja apresentaram resultados mais efetivos. Sendo o coco com sorção de até $1,73 \mathrm{~g} / \mathrm{g}$ e a laranja $0,90 \mathrm{~g} / \mathrm{g}$ em óleos contaminantes. Neste sistema também houve aumento da sorção quando os biossorventes foram comparados por granulometria, com o coco ultrapassando 100\% em óleo diesel e 400\% em gasolina. 
As isotermas de sorção apresentaram melhor ajuste na modelagem de Freundlich, onde todos os coeficientes de correlação de Pearson ficaram acima de 0,9. Os gráficos de $q_{e}$ versus $C_{e}$ demostraram curvas convexas, favoráveis ao processo de sorção para os três biossorventes. De acordo com Giles et al., (1974), estas curvas podem ser classificadas como do tipo $\mathrm{H}$ (high affinity), onde se encaixam como um caso especial de curva tipo $L$, o que indica alta afinidade do sorvente pelo soluto sorvido.

Para avaliação do melhor desempenho sortivo, em relação as isotermas foram utilizados os coeficientes $\mathrm{n}$ de Freundlich. Os três biossorventes foram eficientes, sendo considerados os melhores o coco na granulometria de $<0,25 \mathrm{~mm}$ e a laranja em $0,50 \mathrm{~mm}$. A classificação granulométrica demostrou aumento médio de $5 \%$ na sorção pelo método das isotermas.

Portanto, os três biossorventes analisados nesta pesquisa são viáveis, sendo o coco o mais eficiente. Estes materiais, com suas características particulares podem ser viáveis em situações envolvendo um acidente de derramamento de óleo diesel ou gasolina em corpos hídricos urbanos.

Pesquisas futuras podem abordar um sistema ou protótipo para aglomerar os biossorventes, de forma que possam ser retirados com facilidade da água após a utilização. 


\section{REFERÊNCIAS BIBLIOGRÁFICAS}

AGÊNCIA NACIONAL DE ÁGUAS; Encarte especial sobre a crise hídrica, conjuntura dos recursos hídricos no Brasil 2014. Superintendência de Planejamento de Recursos Hídricos SPR, Brasília, 2015.

AGÊNCIA NACIONAL DE PETRÓLEO, GÁS NATURAL E BIOCOMBUSTÍVEIS (a). O Petróleo, 2017. Disponível em: <http://www.anp.gov.br/wwwanp/petroleo-ederivados2/petroleo>. Acesso em: 12 dez. 2017.

AGÊNCIA NACIONAL DE PETRÓLEO, GÁS NATURAL E BIOCOMBUSTÍVEIS (b). Anuário estatístico, 2017. Disponível em: < http://www.anp.gov.br/wwwanp/images/publicacoes/anuario-estatistico/2017/ Textos/Secao1.pdf>. Acesso em: 12 dez. 2017.

AGÊNCIA NACIONAL DE PETRÓLEO, GÁS NATURAL E BIOCOMBUSTÍVEIS (c). Oportunidades no setor de petróleo e gás natural no Brasil: Rodadas de licitações $2017 \quad-\quad 2019,2017 . \quad$ Disponível em: <http://www.anp.gov.br/wwwanp/images/publicacoes/Oportunidades-no-Setor-dePetroleo-e-Gas-Natural-no-Brasil_v3.pdf>. Acesso em: 12 dez. 2017.

AGÊNCIA NACIONAL DE PETRÓLEO, GÁS NATURAL E BIOCOMBUSTÍVEIS (d). Oportunidades na produção e abastecimento de combustíveis no Brasil, 2017. Disponível em: <http://www.anp.gov.br/wwwanp/images/publicacoes/ Livreto_Oportunidades_na_Produ\%C3\%A7\%C3\%A3o_e_no_Abastecimento_v2.p df>. Acesso em: 12 dez. 2017.

ANDRÉ, J. Caminhão tomba e deixa vazar 15 mil litros de gasolina, 2015. Disponível em: <https://www.tribunapr.com.br/noticias/parana/caminhao-tomba-edeixa-vazar-15-mil-litros-de-gasolina/>. Acesso em: 04 jul. 2018.

ANNUNCIADO, T. R. Estudo da chorisia speciosa e outras fibras vegetais como sorventes para o setor de petróleo. Dissertação de Mestrado, Universidade Federal do Paraná, 2005.

AQUINO, A. R.; PALETTA, F. C.; SILVA, A. C. M.; GALVÃO, A. S.; BORDON, I. C. A.; RIBEIRO, L. S. S.; STECHER, L.; OLIVEIRA, M. J. A.; SILVA, M. V.; SANTOS, R. M.; MATTIOLO, S. R.; SCAGLIUSI, S. R.; GARCIA, V. S. G. Sustentabilidade Ambiental. 1. ed. Rio de Janeiro: Rede Sirius; OUERJ, 2015.

ARÊDES, M. N.; GENRICH, A. V. S.; MAGALHÃES JR, A. P. Degradação dos recursos hídricos em bacias hidrográficas - alto-médio vale do córrego do Parado / São João do Oriente, MG. Geonomos, n.13, p. 47-49, 2013.

A TRIBUNA. Após acidente, quase 12 mil litros de óleo são derramados em rio, 2017. Disponível em: <http://www.atribuna.com.br/noticias/noticiasdetalhe/sao-vicente/acidente-de-trem-causa-derramamento-de-oleo-diesel-emsao-vicente/> Acesso em: 09 mar. 2018. 
BARBOSA, A. L. S.; CUNHA, C. D.; LEITE, S. G. F. Avaliação de material sorvente alternativo para sorção contínua de óleos e graxas e arsênio. In: SIMPÓSIO NACIONAL DE BIOPROCESSOS CAXIAS DO SUL, 6., 2011, Rio Grande do Sul. Anais... Rio Grande do Sul: SINAFER, 2011. p. 1-6.

BELISÁRIO, M.; ZANAROTTO, R.; RAYMUNDO, A. S.; RIBEIRO, J. N.; FLORES, A. V.; RIBEIRO, N. A casca de banana como bioadsorvente na remoção de corantes tóxicos presentes em efluentes industriais. Analytica, n. 48, p. 95-101, 2010.

BENELLI, P.; Agregação de valor ao bagaço de laranja (citrus sinensis I. Osbeck) mediante obtenção de extratos bioativos através de diferentes técnicas de extração. Dissertação de Mestrado, Universidade Federal de Santa Catarina, 2010.

BENEVIDES, L. C. Pirólise do bagaço de laranja: análise cinética dos estágios de secagem e devolatização. Dissertação de Mestrado, Universidade Federal do Espírito Santo, 2015.

BIERMANN, O.; HADICKE, E.; KOLTZENBURG, S; MULLER-PLATHE, F. Hydrophilicity and lipophilicity of cellulose crystal surfaces. Angew Chemie Int. v. 40, n. 20, p. 3822-3825, 2001.

BONETTO, L. R. Estudo da adsorção do corante azul de metileno por um resíduo sólido da indústria de suco de maçã. Dissertação de Mestrado, Universidade de Caxias do Sul, 2016.

BONIOLO, M. R. Biossorção de urânio nas cascas de banana. Dissertação de Mestrado, Instituto de Pesquisas Energéticas e Nucleares, 2008.

BORGES, T. S. Utilização da fibra da bananeira como adsorvente em derramamento de petróleo. Dissertação de Mestrado, Universidade Federal da Bahia, 2015.

CARVALHO, C. et. al., Anuário Brasileiro da Fruticultura. Gazeta Santa Cruz, v. 88, p. 1-89, 2017.

CARVALHO, W.; CANILHA L.; FERRAZ, A.; MILAGRES, A. M. S. Uma visão sobre a estrutura, composição e biodegradação da madeira. Química Nova, v. 32, n. 8, p. 2191-2195, 2009.

CETESB a, (COMPANHIA AMBIENTAL DO ESTADO DE SÃO PAULO). Breve história do petróleo no brasil e em São Paulo e principais acidentes, 2012. Disponível em: <http://cetesb.sp.gov.br/emergencias-quimicas/tipos-deacidentes/vazamentos-de-oleo/panorama-geral/>. Acesso em: 05 jul. 2018.

CETESB b, (COMPANHIA AMBIENTAL DO ESTADO DE SÃO PAULO). Legislação e Convenções, 2018. Disponível em: < http://cetesb.sp.gov.br/emergencias-quimicas/tipos-de-acidentes/vazamentos-deoleo/legislacao-e-convencoes/>. Acesso em: 05 jul. 2018. 
CLAESSON, P. M.; KJELLIN, M.; ROJAS, O. J.; STUBENRAUCH, C. Short-range interactions between non-ionic surfactant layers. Physical Chemistry Chemical Physics. v. 8, n. 47, p. 5501-5514, 2006.

CONFEDERAÇÃO NACIONAL DO TRANSPORTE. Os impactos da má qualidade do óleo diesel brasileiro, 2012. Disponível em: < http://cms.cnt.org.br/Imagens\%20CNT/Site\%202015/Pesquisas\%20PDF/Os\%20i mpactos\%20da\%20m\%C3\%A1\%20qualidade\%20do\%20\%C3\%B3leo\%20diesel\% 20brasileiro.pdf>. Acesso em: 19 dez. 2017.

COONEY, D. O. Adsorption Design for Wastewater Treatment. Florida: CRC Press, 1999.

CORSEUIL, H. X.; MARINS, M. D. M. Contaminação de águas subterrâneas por derramamento de gasolina: o problema é grave? Revista Engenharia Sanitária e Ambiental, v.2, n.2, p.50-54, 1997.

CORSEUIL, H. X.; MARINS, M. D. M. Efeitos causados pela mistura de gasolina e álcool em contaminações de águas subterrâneas. Bol. téc. PETROBRAS, v. 41, n. 3/4, p. 133-138, 1998.

CORTEZ, L. A. B.; PEREZ, J. M. M.; ROCHA, J. D.; JORDAN, R. A.; MESA, H. R. $M$. Processamento da casca e fibra do coco verde por carbonização para agregação de valor. BioEng, v. 3, p. 21-30, 2009.

COSTA, F. O.; SILVA, A. M.; CARVALHO, E. S.; SILVA, V. L. M. M.; LIMA, L. M. R. Uso da casca da banana como bioadsorvente em leito diferencial na adsorção de compostos orgânicos. Encontro Nacional de Educação Ciência e Tecnologia, Universidade Estadual da Paraíba, 2012.

CRUZ, M. A. R. F. Utilização da casca da banana como biossorvente. Dissertação de mestrado, Universidade Estadual de Londrina, 2009.

DEEPA, B.; ABRAHAM, E.; CHERIAN, B. M.; BISMARCK, A.; BLAKER, J. J.; POTHAN, L. A.; LEAO, A. L.; DE SOUZA, S. F.; KOTTAISAMY, M. Structure, morphology and thermal characteristics of banana nano fibers obtained by steam explosion. Bioresource Technology, v. 102, n. 2, p. 1988-1997, 2011.

DIN, A.T.M.; HAMEED, B.H. Adsorption of methyl violet dye on acid modified activated carbon: isotherms and thermodynamics. Journal of Applied Sciences in Environmental Sanitation, v. 5, n. 2, p. 161-170, 2010.

FARINAS, C. S. A parede celular vegetal e as enzimas envolvidas na sua degradação. Embrapa Instrumentação, v. 54, p. 1-16, 2011.

FERREIRA, R. V. P. Aplicação de biossorventes no tratamento de rejeitos radioativos líquidos. Tese de Doutorado, Instituto de Pesquisas Energéticas e Nucleares, 2014. 
FONSECA, H. C. O. Estudo da remoção de $\mathrm{Sr}^{2+}$ de soluções aquosas utilizando fibras de coco bruta e ativada com peróxido de hidrogênio em meio básico. Dissertação de Mestrado, Instituto de Pesquisas Energéticas e Nucleares, 2015.

G1a. Ônibus bate em carro e cai em represa na Grande SP, 2018. Disponível em: $\quad<$ https://g1.globo.com/sp/sao-paulo/noticia/onibus-bate-em-carro-e-cai-emrepresa-na-grande-sp.ghtml>. Acesso em: 09 mar. 2018.

G1b. CETESB investiga mancha de óleo no rio Tietê, 2018. Disponível em: <http://g1.globo.com/sao-paulo/sptv-1edicao/videos/t/edicoes/v/cetesb-investigamancha-de-oleo-no-rio-tiete/6453436/>. Acesso em: 29 jan. 2018.

GADD, G. M. Biosorption: critical review of scientific rationale, environmental importance and significance for pollution treatment. Wiley Interscience, v. 84, p. 13-28, 2008.

GEADA, O. M. R. N. D. Remoção de corantes têxteis utilizando resíduos agrícolas da produção de milho. Dissertação de Mestrado, Faculdade de Engenharia da Universidade do Porto, 2006.

GILES, C. H.; SMITH, D.; HUITSON, A. A general treatment and classification of the solute adsorption isotherm. Journal of Colloid and Interface Science, v. 47, n. 3, p. 755-765, 1974.

GURGEL, L. V. A. Mercerização e modificação química da celulose e bagaço da cana-de-açúcar com anidrido succínico e trietilenotetramina: Preparação de novos materiais quelantes para adsorção de $\mathrm{Pb}(\mathrm{II}), \mathrm{Cd}(\mathrm{II}), \mathrm{Cr}$ (VI) e Cu (II). Dissertação de Mestrado, Universidade Federal de Ouro Preto, 2007.

HILL, C.A.S.; KHALIL, H.P.S.A.; HALE, M.D. A study of the potential of acetylation to improve the properties of plant fibres. Industrial Crops and Products v.8, p.5363, 1998.

HUBBE, M. A; ROJAS, O. J; FINGAS, M; GUPTA, B.S. Cellulosic substrates for removal of pollutants from aqueous systems: A review.3. Spilled oil and emulsified organic liquids. Bioresources.com, v. 8, n. 2, p. 3038-3097, 2013.

INSTITUTO BRASILEIRO DE GEOGRAFIA E ESTATÍSTICA. Levantamento sistemático da produção agrícola. IBGE, v. 30, n. 9, p. 1-83, set/2017.

JESUS, N. N. M. Remoção de césio e amerício utilizando fibra do coco para aplicação no tratamento radioativo. Dissertação de Mestrado, Instituto de Pesquisas Energéticas e Nucleares, 2013.

KADLA, J. F.; GILBERT, R. D. Cellulose structure: A review. Cellulose Chemistry Technology. v. 34, n. 3-4, p. 197-216, 2000. 
KELLEY, S.S., ROWELL, R.M., DAVIS, M., JURICH, C.K.; IBACH, R. Rapid analysis of the chemical composition of agricultural fibers using near infrared spectroscopy and pyrolysis molecular beam mass spectrometry. Biomass \& Bioenergy, v.27, n.1, p.77-88. 2004.

KIM, Y. M.; LEE, H. W.; KIM, S.; WATANABE, C.; PARK, Y.K; Non-Isothermal Pyrolysis of Citrus Unshiu Peel. Bioenergy Research, n. 8, p. 431-439, 2015.

KROON-BATENBURG, L. M. J.; KROON, J. The crystal and molecular structures of cellulose I and II. Glycoconjugate Journal, v.14, v.5, p. 677-690, 1997.

LEE, B. G.; HAN, J. S.; ROWELL, R. M. Oil sorption by lignocellulosic fiber: Kenaf properties, processing and products. Ag \& Bio Engineering, v. 35, p. 423-433, 1999.

MAGDALENA, C. P. Síntese de zeólitas de cinzas de carvão modificada por surfactante e aplicação na remoção de ácido laranja 8 de solução aquosa: estudo em leito móvel, coluna de leito fixo e avaliação ecotoxicológica. Tese de Doutorado, Instituto de Pesquisas Energéticas e Nucleares, 2015.

MANN, J.; MARRINAN, H. J. Polarized infrared spectra of cellulose I. J. Polymer Science. v. 27, n. 115, p. 595-596, 1958.

MARTINS, C. R; LOPES, W. A; ANDRADE, J. B. Solubilidade de substâncias orgânicas. Química Nova, v. 36, n. 8, p. 1248-1255, 2013.

MARTINS R. C; JESUS JR, L. A. Produção e comercialização de coco no Brasil frente ao comércio internacional: panorama 2014. Embrapa Tabuleiros Costeiros, documento $184 . \quad$ Disponível em: $<$ https://www.researchgate.net/publication/304181837_Producao_e_Comercializa cao_de_Coco_no_Brasil_Frente_ao_Comercio_Internacional_Panorama_2014>. Acesso em: $1 \overline{1}$ dez. $201 \overline{7}$.

MARTINS, W. A.; OlIVEIRA, A. M. B. M.; MORAIS, C. E. P.; COELHO, L. F. O.; MEDEIROS, J. F. Reaproveitamento de resíduos industriais de casca de banana para tratamento de efluentes. Revista Verde de Agroecologia e Desenvolvimento Sustentável, v. 10, n. 1, p. 96-102, 2015.

MEYER, E. E.; ROSENBERG, K. J.; ISRAELACHVILI, J. Recent progress in understanding hydrophobic interactions. Proc Nat Acad Sci. v. 103, n. 43, p. 15739-15746, 2006.

MICHALAK, I.; CHOJNACKA K.; WITEK-KROWIAK, A. State of the art for the biosorption process - a review. Appl Biochem Biotechnol, v. 170, p. 1389-1416, 2013.

MONTEIRO, R. A. Avaliação do potencial de adsorção de $U$, $T h, P b, Z n$ e $\mathbf{N i}$ pelas fibras do coco. Dissertação de Mestrado, Instituto de Pesquisas Energéticas e Nucleares, 2009. 
NAJA, G.; VOLESKY, B. The Mechanism of metal cation and anion biosorption; In: KOTRBA, P.; MACKOVA, M.; MACEK, T. Microbial biosorption of metals, Londres, Springer, p. 19-58, 2011.

NASCIMENTO, R. F.; ALVES DE LIMA, A. C.; VIDAL, C. B.; MELO, D. Q.; RAULINO, G. S. C. Adsorção: aspectos teóricos e aplicações ambientais. UFC, Fortaleza, 2014.

OGATA, B. H. Caracterização das frações celulose, hemicelulose e lignina de diferentes genótipos de cana-de-açúcar e potencial de uso em biorrefinarias. Dissertação de Mestrado, Escola Superior de Agricultura "Luiz de Queiroz", 2013.

OLIVEIRA, A. F. Avaliação de desempenho de fibras lignocelulósicas na sorção de óleo diesel e biodiesel. Tese de Doutorado, Universidade Estadual Paulista "Júlio de Mesquita Filho", 2010.

PANIAGUA, C. E. S.; BORGES, S. S. O.; COELHO, N. M. M.; Estudo de caracterização da farinha da casca da banana na forma in natura e quimicamente modificada com tiosemicarbazida como biossorvente para As (III). In Anais... 55은 Congresso Brasileiro de Química, Goiânia - GO, 2015.

PAULA, G. P. Formulação e caracterização de compósitos com fibras vegetais e matriz termoplástica. Dissertação de mestrado, Universidade Estadual do Norte Fluminense Darcy Ribeiro, 2011.

PAYNE, K. C.; JACKSON, C. D.; AIZPURUA, C. E.; ROJAS, O. J.; HUBBE, M. A. Oil spills abatement: Factors effection oil uptake by cellulosic fibers. Environmental Science Technology. v. 46, n. 14, p. 7725-7730, 2012.

PEREIRA, A. L. S. Extração de nanocelulose de fibras vegetais. Dissertação de Mestrado, Universidade Federal do Ceará, 2010.

PETROBRAS. Disponível em: <http://www.petrobras.com.br/pt/>. Acesso em: 20 dez. 2017.

POTT, C. M.; ESTRELA, C. C. Histórico ambiental: desastres ambientais e o despertar de um novo pensamento. Estudos Avançados. v. 89, n. 31, p. 271-283, 2017.

RAJAKOVI'C-OGNJANOVI'C, V.; ALEKSI', G.; RAJAKOVI', L. Governing factors for motor oil removal from water with different sorption materials. Journal of Hazardous Materials, v. 154, p. 558-563, 2008.

RAMBO, M. K. D.; RAMBO, M. C. D.; ALMEIDA, K. J. C. R.; ALEXANDRE, G. P. Estudo de análise termogravimétrica de diferentes biomassas lignocelulósicas utilizando a análise por componentes principais. Ciência e Natura. v. 34, n. 3, p. 862-868, 2015. 
RIBEIRO, T. H.; SMITH, R. W.; RUBIO, J. Sorption of Oils by the Nonlinving Biomass of a Salvínia sp. Environmental Science \& Technology. v. 34, n. 24, p. 5201-5205, 2000.

RIBEIRO, T. M. H. Sorção de petróleos na biomassa seca do macrófito aquático. Tese de Doutorado, Universidade Federal do Rio Grande do Sul, 2000. ROJA, M. L. B.; NEVES, J. M.; Caracterização de fibras de bananeira "nanicão" (musa grupo aaa, "giant cavendish") como possível matéria-prima para produção de pasta celulósica para fabricação de papel; In: Anais... Congresso Iberoamericano de Investigación em Celulosa y Papel, 2002.

SÁNCHEZ, R. O.; HERNÁNDEZ, P. B.; MORALES, G. R.; NÚÑEZ, F. U.; VILLAFUERTE, J. O.; LUGO, V. L., RAMÍREZ, N. F., DÍAZ, C. E. B., VÁSQUEZ, P. C.; Characterization of lignocellulosic fruit waste as an alternative feedstock for bioethanol production. BioResource, v. 9, p. 1873-1885, 2014.

SANTOS, C. M. Uso de cascas de laranja como adsorvente de contaminantes no tratamento de água. Dissertação de Mestrado, Universidade Estadual Paulista "Júlio de Mesquita Filho", 2015.

SEGUNDO, P. O. Avaliação da viabilidade do sisal como sorvente de óleo. Monografia de Graduação, Universidade Federal do Rio Grande do Norte, Natal, 2011.

SERVIÇO BRASILEIRO DE APOIO ÀS MICRO E PEQUENAS EMPRESAS. 0 cultivo e o mercado do coco verde, 2016. Disponível em: <http://www.sebrae.com.br/sites/PortalSebrae/artigos/o-cultivo-e-o-mercado-dococo-verde,3aba9e665b182410VgnVCM100000b272010aRCRD>. Acesso em: 06 dez. 2017.

SILVA, F. J. Estudo comparativo da adsorção de cobre(II) com fibras do bagaço de cana-de-açúcar (Saccharum spp.) e da casca do coco verde (Cocos nucifera). In: Anais... 53ํㅡㄹ Congresso Brasileiro de Química. Rio de Janeiro, 2013.

SILVA, G. S.; NETO, A. C.; CAPRI, M. R. Biossorção de Cr(VI) pela casca de banana nanica no tratamento de efluentes. Interfaces Científicas - Saúde e Ambiente, v. 5, n. 1, p. 153-162, 2016.

SOUZA, W. D. M.; ALVES, J. J. F.; OLIVEIRA, T. M. B. F.; OLIVEIRA, D. S. Potencial da casca da laranja como biossorvente alternativo para remoção de metais pesados em águas residuais. In: 5 ENCONTRO REGIONAL DE QUÍMICA \& 4ํㅡㄹ ENCONTRO NACIONAL DE QUÍMICA, 10., 2015, Rio Grande do Norte. Anais... Rio Grande do Norte: BLUCHER CHEMISTRY PROCEEDINGS, 2015. v. 3, n. 1, p. 1-10.

STRÖHER, A. P.; MENEZES, M. L.; FIORENTIN, L. D.; PEREIRA, N. C. Utilização do bagaço de laranja no tratamento de efluente proveniente da lavagem de jeans. e-xacta, v. 5, n. 1, p. 27-37, 2012. 
TIBOLLA, H. Produção de nanofibras de celulose por hidrólise enzimática. Dissertação de Mestrado, Universidade Estadual de Campinas, 2014.

TRAN, H. N.; YOU, S. J.; BANDEGHARAEI, A. H.; CHAO, H. P. Mistakes and inconsistencies regarding adsorption of contaminants from aqueous solutions: $A$ critical review. Water Research, v. 120, p. 88-116, 2017.

VIEIRA, L. M. Brasil é o terceiro produtor de banana, 2015. Campo \& Negócio. Disponível em: <http://www.revistacampoenegocios.com.br/brasil-e-o-terceiromaior-produtor-de-banana/>. Acesso em: 07 dez. 2017.

VIVIAN, R. B. Análise de contaminação de solo e água subterrânea por hidrocarbonetos derivados de petróleo. Dissertação de mestrado, Universidade Federal de Santa Maria, 2015.

YAMANE, C.; AOYAGI, T.; AGO, M., SATO, K.; OKAJIMA, K.; TAKAHASHI, T. Two different surface properties of regenerate cellulose due to structural anisotropy. Polymer J. v. 38, n. 8, p. 819-826, 2006. 